\title{
Flora da Bahia: Loganiaceae
}

\section{Ellen Kallyne de Sousa Brandão* \& Alessandro Rapinia}

Programa de Pós-graduação em Botânica, Departamento de Ciências Biológicas, Universidade Estadual de Feira de Santana, Feira de Santana, Bahia, Brasil.

Resumo - Apresentamos aqui o tratamento para as Loganiaceae do estado da Bahia. São reconhecidos três gêneros e 42 espécies, representando mais de $90 \%$ das espécies de Loganiaceae da Região Nordeste. Além de Antonia ovata, foram registradas 21 espécies de Strychnos (2 endêmicas) e 20 de Spigelia (8). O tratamento inclui descrições, ilustrações, chaves de identificação para os gêneros e espécies nativos do estado, bem como comentários e mapas de distribuição geográfica das espécies na Bahia.

Palavras-chave adicionais: conservação, florística, Nordeste, Spigelia, Strychnos, taxonomia.

\begin{abstract}
Flora of Bahia: Loganiaceae) - Here, we present the treatment of the Loganiaceae of Bahia state. Three genera and 42 species are recognized, representing more than $90 \%$ of the species of Loganiaceae from Northeast Brazil. Besides Antonia ovata, 21 species of Strychnos ( 2 endemic to Bahia) and 20 of Spigelia (8) were reported. The treatment includes descriptions, illustrations, identification keys for native genera and species, as well as comments and maps of the geographical distribution of species in Bahia.
\end{abstract}

Additional key words: conservation, floristics, Northeast Brazil, Spigelia, Strychnos, taxonomy.

\section{LOGANIACEAE}

Ervas, lianas, arbustos ou árvores. Folhas opostas e/ou verticiladas; lâmina inteira, venação eucamptódroma, subacródroma ou hifódroma; estípulas interpeciolares, por vezes reduzidas a uma linha estipular. Cimeiras escorpioides (drepânios) ou tirsos, uni ou multifloros, terminais ou axilares; brácteas frequentemente acompanhando as flores (escamiformes em Antonia Pohl). Flores bissexuadas, (4)5(6)-meras, diclamídeas, sésseis a curtopediceladas. Cálice gamossépalo a dialissépalo, decíduo ou persistente no fruto; sépalas imbricadas. Corola gamopétala, valvar ou imbricada, actinomorfas, infundibuliforme, hipocrateriforme, campanulada, raramente urceolada. Estames (4)5(6), inclusos ou exsertos, isodínamos, epipétalos; filetes filiformes; anteras dorsifixas ou basifixas, rimosas. Ovário súpero, bicarpelar, bilocular, uni ou pluriovulado, placentação axilar; estilete incluso ou exserto; estigma filiforme, capitado (indiviso) ou bífido. Cápsulas septicidas, septo-loculicidas ou bagas. Sementes, 1, 2 ou numerosas por fruto, muricadas, reticuladas ou lisas.

As Loganiaceae R.Br. ex Mart. s.str., pertencem às Gentianales. Estudos moleculares reconhecem a família como monofilética com 15 gêneros, quatro tribos e cerca de 420 espécies (Backlund et al. 2000; Frasier 2008; Gibbons et al. 2012; Yang et al. 2016). Possuem distribuição pantropical, sendo típicas de ambientes secos e raras em altitudes acima de $3.000 \mathrm{~m}$ (Heywood 1985). O Brasil apresenta uma grande

\footnotetext{
*Autora para correspondência: ellenkallyne_@hotmail.com;

${ }^{a}$ rapinibot@yahoo.com.br

Editor responsável: Pedro Fiaschi

Submetido: 21 nov. 2017; aceito: 19 abr. 2018

Publicação eletrônica: 27 jun. 2018; versão final: 4 jul. 2018
}

diversidade da família, com cerca de 131 espécies e cinco gêneros, sendo Strychnos L. (68 espécies) e Spigelia L. (56) os gêneros mais representativos (Progel 1868; Guimarães et al. 2017). Para a Bahia, são reconhecidas 42 espécies $\mathrm{e}$ três gêneros: o monoespecífico Antonia (A. ovata Pohl), Spigelia, com 20 espécies (8 endêmicas), e Strychnos, com 21 (2 endêmicas). Spigelia martiana Cham. e S. olfersiana Cham. \& Schltdl. foram referidas uma única vez para a Bahia (Progel 1868), sem indicação de material, colocando em dúvida esses registros para o estado; essas ocorrências são confirmadas aqui pela primeira vez. Por outro lado, Mitreola petiolata (Walter ex J.F.Gmel.) Torr. \& A.Gray, Spigelia kleinii L.B.Sm., S. tetraptera Taub. e Strychnos parviflora Spruce \& Benth. não ocorrem na Bahia e seus registros para o estado refletem identificações equivocadas. A família apresenta ampla distribuição na Bahia, ocorrendo preferencialmente em matas e campos rupestres, e mais raramente em cerrados e caatingas.

\section{Chave para os gêneros}

1. Ervas, subarbustos ou raramente arbustos eretos; inflorescências em cimeiras escorpioides (drepânios) ou flores solitárias (eventualmente cimeiras congestas não escorpioides em S. flava); estilete articulado na porção basal; carpoatlas presente .............................................. 2. Spigelia

1'. Cipós ou arbustos escandentes, raramente árvores ou arbustos eretos; inflorescências em tirsos; estilete não articulado; carpoatlas ausente.

2. Árvores, arvoretas ou arbustos eretos; lâmina foliar eucamptódroma; frutos cápsulas; sementes aladas ............................................. 1. Antonia

2'. Cipós, arbustos escandentes (exceto $S$. nana) ou raramente árvores; lâmina foliar subacródomas; frutos bagas; sementes sem alas .... 3. Strychnos 


\section{Antonia Pohl}

Arvoretas ou arbustos, raramente árvores; ramos lenticelados ou não; gavinhas e/ou espinhos ausentes. Folhas opostas; venação eucamptódroma; estípulas lineares. Tirsos terminais, um por ramo, multifloros; brácteas 4 ou 5 pares envolvendo cada flor, escamiformes. Flores 5-meras. Cálice dialissépalo, persistente; sépalas iguais entre si. Corola hipocrateriforme. Estames exsertos; anteras dorsifixas, oblongas, glabras. Ovário uniovulado; estilete exserto, não articulado, ausente no fruto; estigma inteiro, bífido, geralmente conado. Cápsulas septo-loculicidas, oblongas, bífidas no ápice. Carpoatlas ausente. Sementes acinzentadas a negrejantes, 2, oblongas, comprimidas, com alas membranáceas.

Antonia é um gênero monoespecífico, com distribuição restrita à América do Sul, desde as Guianas, passando pelo Suriname, Venezuela, Peru e Bolívia. No Brasil, está amplamente distribuído, porém encontra-se ausente nos estados mais no nordeste do país e tem em Goiás e Minas Gerais seu limite sul de distribuição (Pohl 1831; Progel 1868; Guimarães et al. 2017).

\subsection{Antonia ovata Pohl, Pl. Bras. Icon. Descr. 2: 13} 1829.

Figuras 1, 2 e 30A, B.

\section{Nome popular: vela-branca}

Árvore, arvoreta ou arbusto, $1-5 \mathrm{~m}$ alt.; ramos castanho-escuros a verde-oliva, cilíndricos, lenticelados, glabros a densamente pubescentes. Folhas com pecíolo amplexicaule, até $0,5 \mathrm{~cm}$ compr.; lâmina castanha a verde-oliva, $1-7 \times 1-5,2 \mathrm{~cm}$, ovada a ovado-elíptica, arredondada a cuneada na base, arredondada a aguda no ápice, levemente revoluta nas margens, subcoriácea a coriácea, glabra a densamente pubescente em ambas as faces, tricomas por vezes restritos às nervuras principal e secundárias, 4-7 pares de nervuras secundárias; estípulas lineares. Cimeiras com 50 ou mais flores; pedúnculo $1-5 \mathrm{~cm}$ compr., glabro a pubescente; brácteas $1-4,5 \mathrm{~mm}$ compr., deltoides a ovadas, agudas a arredondadas no ápice, ciliadas nas margens. Flores subtendidas por 4 pares de brácteas, subsésseis ou pedicelo até $0,5 \mathrm{~mm}$ compr. Sépalas 4-5 × 1-2 $\mathrm{mm}$, oblongas, arredondadas no ápice, ciliadas nas margens. Corola branca a creme; tubo 3-5 $\mathrm{mm}$ compr., externamente glabro, internamente piloso na fauce; lobos 3,4-5 $\times$ 0,6-1,2 mm, oblongo-lanceolados, glabros. Filetes 2 $3 \mathrm{~mm}$ compr.; anteras ca. $2 \mathrm{~mm}$ compr. Ovário $2-3,5$ mm compr.; estilete 5-7 $\mathrm{mm}$ compr. Cápsulas castanhas, $8-9 \times 2,5-3 \mathrm{~mm}$, pubérulas no ápice. Sementes $2,5-3 \times 1,5-1,8 \mathrm{~mm}$.

Está representada nas Regiões Norte, Nordeste, Centro-Oeste e Sudeste, nos domínios da Amazônia, Caatinga, Mata Attântica e, principalmente, do Cerrado (Guimarães et al. 2017). D1, E2/3, E6, F2, F4, F5, F6, G2, G5 e G6: cerrados, eventualmente em transição para os campos rupestres, crescendo exposta ao sol, sobre solos areno-argilosos ou areno-pedregosos. Floresce e frutifica praticamente o ano.

Material selecionado - Abaíra, $13^{\circ} 17^{\prime} 09^{\prime \prime} \mathrm{S}, 41^{\circ} 48^{\prime} 00^{\prime \prime} \mathrm{W}, 13$ maio 2000 (fl., fr.), E.B. Miranda et al. 453 (CEPEC, HUEFS); Andaraí, 12 $2^{\circ} 52^{\prime} 59^{\prime \prime} \mathrm{S}, 41^{\circ} 18^{\prime} 09^{\prime \prime} \mathrm{W}, 31 \mathrm{mar} .2004$ (fl.), R. Funch \& L.S. Funch 61 (HUEFS); Barreiras, $12^{\circ} 09^{\prime} 10^{\prime \prime} \mathrm{S}, 44^{\circ} 59^{\prime} 24^{\prime \prime} \mathrm{W}, 11$ jun. 1992 (fl.), A.M. Carvalho 4001 (CEPEC); Caetité, 14¹9'23"S, 42 $23^{\prime} 34^{\prime \prime} \mathrm{W}$, ago. 2008 (fl.), M.S. Mendes et al. 452 (HUEFS); Catolés, $13^{\circ} 16^{\prime} \mathrm{S}, 41^{\circ} 49^{\prime} \mathrm{W}, 30$ abr. 2006 (fl.), M.L. Guedes et al. 12246 (ALCB); Cocos, 1453'25"S, 4540'12"W, 6 jul. 2001 (fl.), M.L. Fonseca 2862 (RB); Correntina, 13 $30^{\circ} \mathrm{S}, 45^{\circ} 49^{\prime \prime} \mathrm{W}, 29$ jul. 1989 (fl.), B.J. Dias 48 (RB); Érico Cardoso, 1316'36"S, 42 $066^{\prime} 54^{\prime \prime} \mathrm{W}, 4$ jul. 2001 (fl.), H.P. Bautista et al. 3294 (ALCB, CEPEC, HUEFS); Formosa do Rio Preto, $11^{\circ} 12^{\prime} 51^{\prime \prime S}$, $45^{\circ} 45^{\prime} 48^{\prime \prime} \mathrm{W}, 30$ jul. 2006 (fl.), R.P. Oliveira et al. 478 (ALCB, CEPEC, HUEFS); Guanambi, $14^{\circ} 12^{\prime} 58^{\prime \prime} \mathrm{S}, 42^{\circ} 46^{\prime} 39^{\prime \prime} \mathrm{W}, 23$ jul. 1980 (fl.), C.A. Miranda s.n. (RB 203087); Ibicoara, $13^{\circ} 19^{\prime} 32^{\prime \prime S}$, $41^{\circ} 08^{\prime} 44^{\prime \prime W}, 31$ jan. 2011 (fl.), H.A. Ogasawara 63 (ALCB); Lençóis, $12^{\circ} 31^{\prime \prime} \mathrm{S}, 41^{\circ} 22^{\prime} \mathrm{W}, 30$ jul. 2006 (fl.), L.S. Funch \& R. Funch 40 (ALCB, HUEFS); Licínio de Almeida, 14²7'50"S, 42 $31^{\prime} 30^{\prime \prime W}, 10$ dez. 2009 (fl.), M.L. Guedes et al. 16761 (ALCB, HUEFS); Macaúbas, $12^{\circ} 05^{\prime} 00^{\prime \prime S}, 42^{\circ} 45^{\prime} 11 " \mathrm{~W}, 7$ jul. 2007 (fr.), A.A. Conceição et al. 2488 (ALCB, CEPEC, HUEFS); Mucugê, 16 $6^{\circ} 01^{\prime} 53^{\prime \prime S}, 41^{\circ} 16^{\prime} 27^{\prime \prime} \mathrm{W}, 17$ ago. 2016 (fl., fr.), E.K.S. Brandão et al. 104 (HUEFS); Palmeiras, $12^{\circ} 26^{\prime} 17^{\prime \prime S}, 41^{\circ} 30^{\prime} 52^{\prime \prime} \mathrm{W}, 18$ abr. 2010 (fl.), S.P.S. Neves 218 (HUEFS); Piatã, 12 $04^{\prime} 12^{\prime \prime S}$, $41^{\circ} 46^{\prime} 56^{\prime \prime} \mathrm{W}, 5$ out. 1996 (fr.), R.M. Harley et al. 28268 (HUEFS); Rio de Contas, $13^{\circ} 26^{\prime} 30^{\prime \prime} \mathrm{S}, 41^{\circ} 45^{\prime} 10^{\prime \prime} \mathrm{W}, 16$ abr. 2003 (fl.), A.M. Giulietti et al. 2254 (HUEFS); São Desidério, 12²1'56"S, 44 $59^{\prime} 08^{\prime \prime W}, 23$ jul. 2008 (fl.), A.M. Miranda et al. 5802 (HUEFS); Utinga, $12^{\circ} 10^{\prime} \mathrm{S}, 41^{\circ} 19^{\prime} \mathrm{W}, 17$ out. 1994 (fl.), L.P. Queiroz \& N.S. Nascimento 4213 (CEPEC, HUEFS, RB, UEC).

Antonia ovata é geralmente uma arvoreta, com flores brancas e coriáceas, de aroma adocicado. Progel (1868) e Zappi (1989) reconhecem duas variedades: a var. ovata, com ramos e folhas completamente glabros,

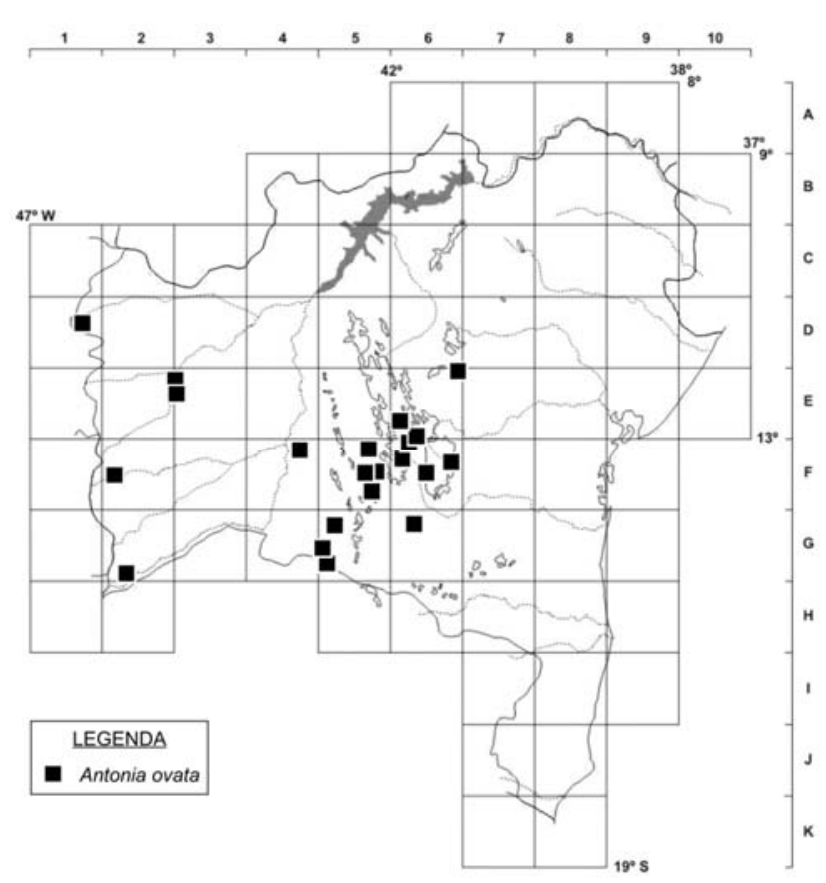

Figura 1. Mapa de distribuição de Antonia ovata no estado da Bahia. 


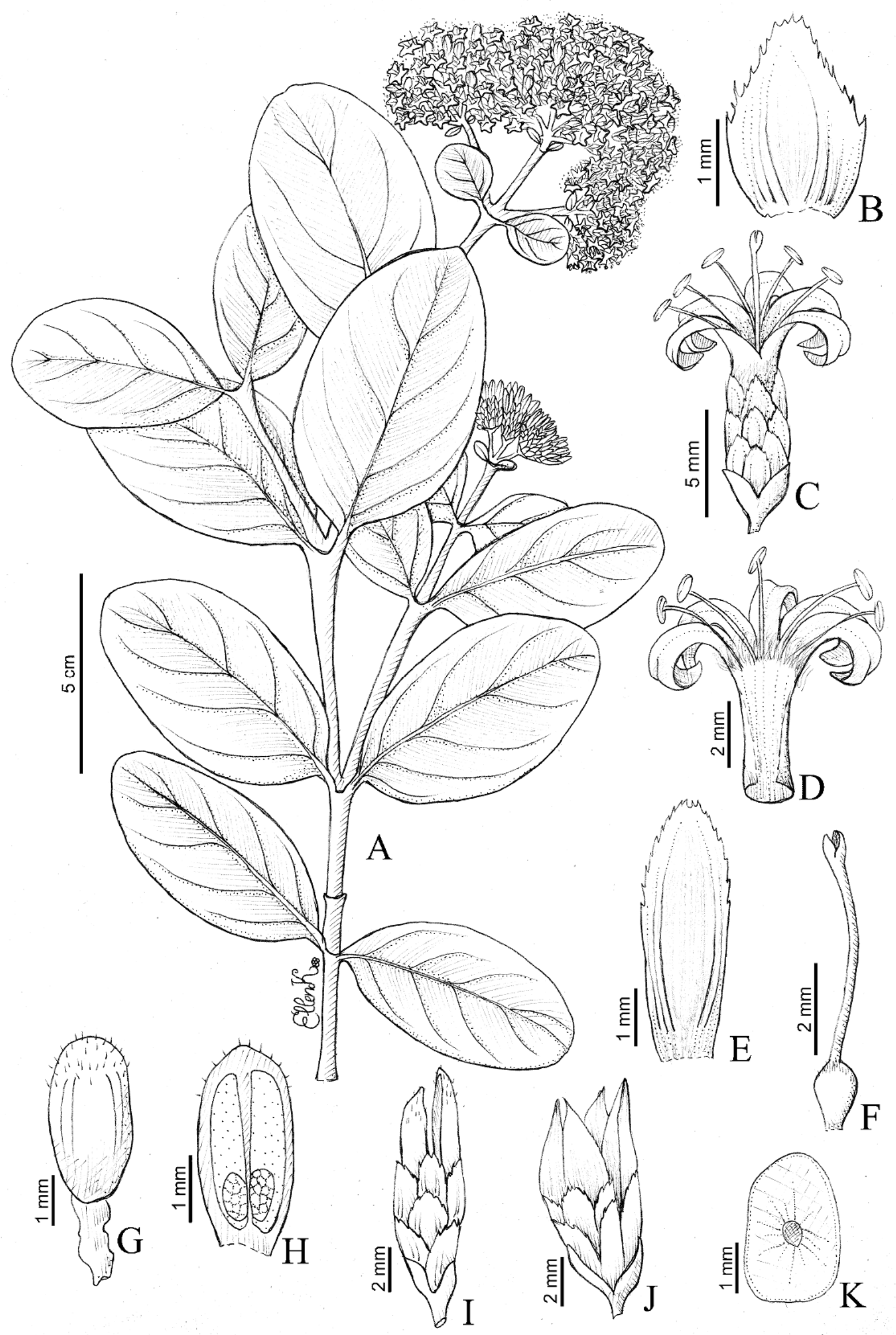

Figura 2. Antonia ovata: A- ramo fértil; B- bráctea, face abaxial; C- flor; D- corola aberta; E- sépala, face abaxial; F- pistilo; G- ovário; H- ovário, corte longitudinal expondo os óvulos; I- cápsula imatura; J- cápsula madura com brácteas persistentes; K- semente, face ventral. (A-H- Funch 133; I-K- Brandão 121). 
e a var. pilosa Progel, completamente pubérula a pubescente, com tricomas concentrados principalmente nas nervuras principais, ao longo do caule e dos ramos jovens. Nos herbários, o gênero Bonyunia M.R.Schomb. ex Progel (Loganiaceae) é frequentemente confundido com Antonia, devido à similaridade desses gêneros em relação ao hábito e tipo de fruto. No entanto, Bonyunia não possui a série de 4 pares de brácteas na base das flores, presente em $A$. ovata mesmo após a frutificação.

\section{Spigelia L.}

Ervas, raramente subarbustos ou arbustos; ramos não lenticelados; gavinhas e/ou espinhos ausentes. Folhas opostas ou verticiladas; venação eucamptódroma ou hifódroma; estípulas deltoides, ovadas a largoovadas, truncadas no ápice ou lineares. Cimeiras escorpioides, uni a multifloras, isoladas ou agrupadas, terminais e/ou axilares; brácteas 1 par por flor, ovadas a lanceoladas. Flores 5-meras. Cálice dialissépalo, persistente; sépalas desiguais. Corola infundibuliforme, campanulada ou urceolada. Estames inclusos ou exsertos, articulados, porção basal persistente no fruto; estigma linear ou clavado. Cápsulas loculicidas, dicocas, circuncisas na base. Carpoatlas presente. Sementes castanhas a negrejantes, numerosas, ovoides a elipsoides; testa muricada ou reticulada.

Spigelia apresenta ampla distribuição, ocorrendo em todos os estados brasileiros, além do Distrito Federal (A.E. Ramos 177, G. J. Shepherd 3618, H.S. Irwin 26652; ocorrência não indicada em Guimarães et al. 2017). Abrange 56 espécies, 20 delas na Bahia, sendo oito endêmicas, seis das quais restritas aos campos rupestres, o principal centro de diversidade do gênero (Zappi 1989; Guimarães et al. 2017): S. cremnophila, S. elsieana, S. flava, S. fontellae, S. kuhlmannii, S. pulchella; além de S. brachystachya e S. genuflexa. Spigelia é prontamente reconhecida pelas cimeiras escorpioides (drepânios), além de apresentar carpoatlas, estrutura proveniente da cápsula, rígida e persistente, mesmo após a queda do fruto. Progel (1868) dividiu o gênero em cinco secções: Anthelmiae Progel, Graciles Progel, Speciosae Progel, Stenophylae Progel e Tomentosae Progel, classificação ainda utilizada, mesmo que de maneira informal, para agrupar e caracterizar as espécies de Spigelia.

\section{Chave para as espécies}

1. Folhas opostas, inclusive no ápice dos ramos.

2. Estames exsertos

2'. Estames inclusos.

2.18. S. pulchella

3. Folhas ovadas a largo-ovadas.

4. Erva reptante

2.5. S. cremnophila

4'. Arbusto a subarbusto ereto, não reptante.

5. Tricomas estrelados por toda planta

2.16. S. olfersiana

5'. Tricomas simples (não estrelados) ou plantas glabras.

6. Folhas ovadas a oblongo-ovadas, não espessadas nas margens, cartáceas a papiráceas; corola $15-19 \mathrm{~mm}$ compr.; mericarpos glabros

2.3. S. blanchetiana

6'. Folhas largo-ovadas, espessadas nas margens, subcoriáceas; corola 33-33,5 mm compr.; mericarpos muricado-papilosos.

2.12. S. kuhlmannii

3'. Folhas lineares, lanceoladas, estreito-oblongas a estreito-elípticas.

7. Ramos 6-10-sulcados (não costados).

8. Ramos com costelas papilosas, principalmente próximo aos nós; folhas lineares (efêmeras).

9. Cimeiras com uma única flor; lâmina foliar $0,15-0,3 \mathrm{~cm}$ compr., papilosa; flores menores que $5 \mathrm{~mm}$ compr.

2.9. S. fontellae

9'. Cimeiras com mais de uma flor; lâmina foliar 0,5-2,5 cm compr., escabra a glabra; flores maiores que $10 \mathrm{~mm}$ compr.

2.14. S. linarioides

8'. Ramos com costelas sem papilas; folhas lanceoladas, estreito-oblongas a estreito-elípticas (persistentes).

10. Erva $7-30 \mathrm{~cm}$ alt.; lâmina foliar $0,2-1,4 \mathrm{~cm}$ compr.; inflorescências geralmente paucifloras (1-8 flores); corola lilás com base esverdeada

2.6. S. elsieana

10'. Erva a subarbusto $35-50 \mathrm{~cm}$ alt.; lâmina foliar 1,5-3 cm compr.; inflorescências geralmente multifloras (3-17 flores); corola creme com guias de néctar rosa.

2.11. S. gracilis

7'. Ramos 4-costados (parecendo tetrágonos; sem sulcos).

11. Erva até $23 \mathrm{~cm}$ alt.; ramos cilíndricos; folhas não revolutas nas margens; corola urceolada, até $1,6 \mathrm{~mm}$ compr.

11'. Erva mais de $30 \mathrm{~cm}$ alt.; ramos tetragonais a subtetragonais; folhas revolutas nas margens; corola infundibuliforme maior que $10 \mathrm{~mm}$ compr. 
12. Erva cespitosa (touceira); folhas cartáceas, hifódroma, esparso-escabras na face adaxial; cimeiras pedunculadas (pedúnculo 1,5-4 cm compr.); sépalas 4-5 $\mathrm{mm}$ compr.

2.20. S. spartioides

12'. Erva ramificada (acima da base); folhas membranáceas, triplinérveas, geralmente glabras; cimeiras sésseis a subsésseis (pedúnculo até $1,5 \mathrm{~cm}$ compr.); sépalas $2-3 \mathrm{~mm}$ compr.

2.15. S. martiana

1'. Folhas verticiladas (ao menos no ápice dos ramos), eventualmente opostas para a base.

13. Folhas verticiladas, subcoriáceas a coriáceas; flores em cimeiras congestas, capituliformes (não escorpioides); flores 35-47 mm compr., amarelas com base púrpura 2.7. S. flava

13'. Folhas verticiladas no ápice ou nós apicais e opostas para a base dos ramos, cartáceas a papiráceas; flores em cimeiras escorpioides (drepânios); flores menores que $25 \mathrm{~mm}$ compr., brancas (com ou sem guias de néctar rosa) ou rosa.

14. Erva até $25 \mathrm{~cm}$ alt.; ramos sulcados, com 6-8 costelas papilosas

2.10. S. genuflexa

14'. Erva geralmente maior que $23 \mathrm{~cm}$ alt.; ramos cilíndricos ou tetrágonos sem costelas, glabros ou escabros.

15. Lâmina foliar esparso-escabra na face adaxial; corola menor que 11(-12) $\mathrm{mm}$ compr.

16. Folhas com venação principal paralela; $3-7$ cimeiras agrupadas .............. 2.1. S. anthelmia

16'. Folhas com venação principal peninérvea; cimeira isolada.

17. Inflorescências com 8-30 flores; mericarpos papilosos. 2.8. S. flemmingiana

17'. Inflorescências com 1-7 flores; mericarpos escabros.

2.19. S. scabra

15'. Lâmina foliar glabra em ambas as faces; corola igual ou maior que $11 \mathrm{~mm}$ compr.

18. Corola menor que $14 \mathrm{~mm}$ compr.; mericarpos muricado-papilosos .. 2.4. S. brachystachya

18'. Corola maior que $15 \mathrm{~mm}$ compr.; mericarpos glabros.

19. Ramos cilíndricos; folhas lanceoladas a ovado-lanceoladas; múltiplas cimeiras terminais e axilares

2.13. S. Iaurina

19'. Ramos tetrágonos, subtetrágonos a achatados; folhas oblongo-elípticas a ovadas; cimeiras isoladas, terminais

2.2. S. beyrichiana

2.1. Spigelia anthelmia L., Sp. Pl. 1: 149. 1753.

Figuras 3A-G, 4 e 30C.

Nome popular: lombrigueira

Erva ereta, $15-50 \mathrm{~cm}$ alt.; ramos verdes, cilíndricos, estriados, glabros. Folhas verticiladas no ápice e opostas para a base dos ramos, sésseis; lâmina verde, discolor, 3-12,5 $\times 1,2-4,8 \mathrm{~cm}$, ovadolanceolada, cuneada a arredondada na base, aguda a acuminada no ápice, membranácea a papirácea, esparso-escabra adaxialmente, glabra abaxialmente, 3 ou 4 pares de nervuras secundárias; estípulas deltoides, ca. $2 \mathrm{~mm}$ compr. Cimeiras escorpioides, em grupos de 3-7, terminais, 6-29 flores, 1,5-14 cm compr.; brácteas $1,5-2 \mathrm{~mm}$ compr., lanceoladas, agudas no ápice, dentículos hialinos nas margens. Flores sésseis ou pedúnculo até $1,5 \mathrm{~mm}$ compr. Sépalas $2-3 \times 0,3-$ $0,4 \mathrm{~mm}$, linear-lanceoladas a lanceoladas, agudas no ápice, dentículos hialinos nas margens. Corola branca com guias de néctar rosa, infundibuliforme; tubo 6-8 mm compr., glabro externa e internamente; lobos $1-1,7$ $\times 1,6-2 \mathrm{~mm}$, deltoides, glabros. Estames inclusos; filetes $2,5-3 \mathrm{~mm}$ compr.; anteras $0,9-1,3 \mathrm{~mm}$ compr. Ovário 1-3,5 mm compr.; estilete ca. 6,5 mm compr.; estigma filiforme. Cápsulas verdes, 4,5-5 × 5-6,5 $\mathrm{mm}$; mericarpos arredondados, muricados, papilosos. Carpoatlas rômbico, agudo nas extremidades; forame elíptico. Sementes 16, 1,2-2 × 1-1,5 mm.

Ocorre na América Central, Bolívia, Colômbia, Estados Unidos, Equador, Guiana Francesa, México, Peru, Suriname e Venezuela. No Brasil, é encontrada no Acre, Amazonas, Pará, Rondônia, Roraima, Tocantins, Mato Grosso, Mato Grosso do Sul, Espírito Santo, São Paulo e em todo o Nordeste (Guimarães et al. 2017). C7, D3, D4, D5, D10, E7, E8, E9, E/F5, F8/9, G7, G8, H8 e I8/9: caatingas, cerrados, florestas ciliares ou de galeria e restingas, em ambientes úmidos, alterados, antrópicos, sombreados ou ensolarados, em solos arenosos e/ou alagados. Encontrada com flores e frutos praticamente $\mathrm{o}$ ano todo.

Material selecionado - Boquira, $1^{\circ} 13^{\prime} 51^{\prime \prime S}, 42^{\circ} 18^{\prime} 21^{\prime \prime W}, 19$ jan. 1997 (fl.), G. Hatschbach 65982 (MBM); Cachoeira, 12³1'S, 3904'W, 10 jun. 1980 (fl., fr.), Grupo Pedra do Cavalo 116 (ALCB, CEPEC, HUEFS); Camaçari, 1241'21"S, 38 $06^{\circ} 28^{\prime \prime} \mathrm{W}, 5$ jun. 2011 (fl.), M.L. Guedes et al. 18192 (ALCB); Cruz das Almas, 1240'12"S, 3906'06"W, mar. 1951 (fl.), G.C.P. Pinto 63 (ALCB, CEPEC); Entre Rios, $12^{\circ} 52^{\prime} \mathrm{S}, 37^{\circ} 57^{\prime} \mathrm{W}, 26$ maio 2007 (fl., fr.), A.V. Popovkin \& D. Cardoso 6 (HUEFS); Feira de Santana, 12¹0'59"S, 38 58'12"W, 9 mar. 2007 (fl., fr.), E.B. Miranda \& F. Pastore 1001 (HUEFS); Formosa do Rio Preto, $11^{\circ} 58^{\prime} \mathrm{S}, 4^{\circ} 57^{\prime} \mathrm{W}, 23$ fev. 2005 (fl.), A.B. Xavier \& L.M. Guedes 349 (ALCB); Gentio do Ouro, 1303'09"S, 42 44'20"W, 3 jun. 1999 (fl., fr.), E. Melo et al. 2755 (HUEFS); Iaçu, 12 $46^{\prime} 01^{\prime \prime S}, 40^{\circ} 12^{\prime} 42^{\prime \prime W}, 9$ abr. 2002 (fl.), G. Hatschbach et al. 56969 (MBM); Ilhéus, 1446'54"S, 3904'09"W, 11 jan. 1995 (fl.), W.W. Thomas 10739 (CEPEC); Itanhém, 1708'17"S, 40²5'33"W, 29 dez.

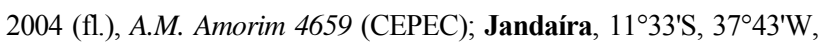
20 jul. 2013 (fl.), F.S. Gomes 1259 (ALCB); Juazeiro, 09²8'50"S, $40^{\circ} 18 ' 50 " \mathrm{~W}, 12$ jun. 2009 (fr.), E. Melo et al. 6333 (HUEFS); Lauro de Freitas, $12^{\circ} 52^{\prime} \mathrm{S}, 38^{\circ} 19^{\prime} \mathrm{W}, 14$ jun. 1987 (fl.), J.R. Silva s.n. (ALCB 20705); Macaúbas, $13^{\circ} 01^{\prime} 09^{\prime \prime} \mathrm{S}, 42^{\circ} 41^{\prime} 54^{\prime \prime W}, 17$ jun. 2004 (fl.), G. Hatschbach et al. 77596 (MBM); Mata de São João, 12³1'49"S, 
38 $17^{\prime} 57^{\prime \prime}$, 18 jun. 2003 (fl.), G. Hatschbach et al. 75468 (ALCB, MBM); Nazaré, 1302'06"S, 3900'51"W, 19 ago. 2009 (fl.), A. Dunaiski Jr. 3745 (MBM); Pau-Brasil, 15²7'27"S, 39³9'24"W, 22 abr. 1982 (fl., fr.), A.M. Carvalho et al. 1322 (HUEFS); Salvador, 1258"S, 38³0'W, 17 mar. 1979 (fl.), L.R. Noblick 1047 (ALCB); Santa Cruz Cabrália, $16^{\circ} 16^{\prime} \mathrm{S}, 39^{\circ} 01^{\prime} \mathrm{W}, 7$ nov. 2000 (fl.), L.M. Pacheco et al. 140 (ALCB); São Félix, 1240'06"S, 3857'58"W, 24 jul. 2012 (fl.), L.Y.S. Aona et al. 1525 (HURB); São Félix do Coribe,

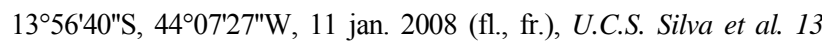
(HUEFS); São Gabriel, 1301'48"S, 4140'12"W, 2 abr. 2009 (fl., fr.), R.F. Machado et al. 114 (HUEFS); São Sebastião do Passé, $12^{\circ} 30^{\prime} 45^{\prime \prime} \mathrm{S}, 38^{\circ} 28^{\prime} 59^{\prime \prime} \mathrm{W}, 17$ out. 1998 (fl.), A.F.S. Nascimento et al. 95 (ALCB, CEPEC); Vera Cruz, 1257'05"S, 38³6'42"W, 9 fev. 1997 (fl., fr.), L.P. Queiroz 4751 (CEPEC, HUEFS, RB).

Spigelia anthelmia é uma erva com ramos fistulosos e flexíveis, folhas com venação eucamptódroma-paralela, sésseis, dispostas em verticilos no ápice dos ramos, múltiplas cimas por ramo e sépalas menores que a metade do comprimento das cápsulas, que são visivelmente muricadas. Assemelha-se a S. hamelioides Kunth, espécie do norte da América do Sul, diferindo pelas folhas sésseis (vs. peciolada), com lâmina ovado-lanceolada (vs. elíptica a oblongo-elíptica), venação eucamptódroma-paralela (vs. peninérvea) e sépalas com comprimento menor (vs. maior) que o da cápsula. É comumente encontrada em áreas alagadas, sendo popularmente conhecida como lombrigueira, por seus compostos anti-helmínticos (Hoehne 1939).

\subsection{Spigelia beyrichiana Cham. \& Schltdl., Linnaea} 1(2): 203.1826.

Figuras 3H-L, 4 e 30D.

Erva ereta, 15-40 cm alt.; ramos castanhos a verdeoliva, tetrágonos, subtetrágonos a achatados, glabros. Folhas verticiladas no ápice e opostas para a base dos ramos, subsésseis ou pecíolo até $0,7 \mathrm{~mm}$ compr.; lâmina castanha a verde-oliva, discolor, 3,5-11 $\times 1-3 \mathrm{~cm}$, oblongo-elíptica a ovada, atenuada a cuneada na base, acuminada a aguda no ápice, papirácea, glabra em ambas as faces, 4-6 pares de nervuras secundárias; estípulas largo-ovadas eventualmente truncadas no ápice, ca. 1,5 $\mathrm{mm}$ compr. Cimeiras escorpioides, isoladas, raramente em grupos de 3, terminais e axilares, 3-7 flores, 5-11 cm compr.; pedúnculo até $2 \mathrm{~cm}$ compr., glabro; brácteas 0,5 1(-2) mm compr., lanceoladas, agudas a acuminadas no ápice, papilosas nas margens. Flores sésseis ou pecíolo até $0,5 \mathrm{~mm}$ compr. Sépalas 1,4-1,8 × 0,6-0,8 mm, ovadas, agudas no ápice, papilosas nas margens. Corola branca, rosada, com ou sem guias de néctar rosa, infundibuliforme; tubo 13-15 mm compr., glabro externa e internamente; lobos 3-3,5 × 3-3,5 mm, ovadodeltoides, glabros. Estames inclusos; filetes 1-1,2 mm compr.; anteras 1,8-2 mm compr. Ovário 1-1,2 mm compr.; estilete até $10 \mathrm{~mm}$ compr.; estigma filiforme. Cápsulas verdes, 3-3,5 × 4-4,5 mm; mericarpos agudos, glabros. Carpoatlas elíptico, arredondado a truncado nas extremidades; forame oblongo a circular. Sementes 6, 1 $1,5 \times 1-1,8 \mathrm{~mm}$.
Endêmica do Brasil, amplamente distribuída em praticamente todo o território nacional (Guimarães et al. 2017). F/G7, G7 e H8/9: florestas ombrófilas montanas e submontanas, sobre solos ricos em húmus, no interior da mata, à sombra ou em locais com pouca incidência luminosa. Foi encontrada com flores em março e agosto e com frutos em fevereiro.

Material selecionado - Ilhéus, $14^{\circ} 47^{\prime 2} 20^{\prime \prime} \mathrm{S}, 39^{\circ} 29^{\prime} 38^{\prime \prime} \mathrm{W}, 10$ mar. 1998 (fl.), T.G. Bacelar 58 (CEPEC); Jequié, 1356'40"S, 4006'33"W, 31 ago. 2007 (fl.), E.B. Miranda et al. 1062 (HUEFS); Una, 15²18'20"S, 3900'18"W, 10 fev. 1999 (fr.), J.G. Jardim 1985 (CEPEC).

Segundo a descrição original, Spigelia beyrichiana é caracterizada pelos ramos tetrágonos, glabros, folhas geralmente ovadas, breve-acuminadas no ápice, com venação sutil, estípulas truncadas, inflorescências geralmente curto-pedunculadas e sépalas 10 vezes mais curtas que a corola (Chamisso \& Schlechtendal 1826). Assemelha-se a $S$. laurina, mas pode ser diferenciada pelos ramos tetrágonos (vs. cilíndricos) e as cimeiras subsésseis a curto-pedunculadas (pedúnculo até $2 \mathrm{~cm}$ vs. mais de $3,5 \mathrm{~cm}$ compr.). Essas espécies são comumente confundidas por apresentarem sobreposição de características, devido principalmente ao polimorfismo de $S$. laurina, sugerindo a necessidade de estudos populacionais detalhados para definir a relação entre elas.

\subsection{Spigelia blanchetiana A.DC in A.P. de Candolle,} Prodr. 9: 4. 1845.

Figuras 3M-P, 4 e 30E.

Erva, raramente subarbusto, $20-40 \mathrm{~cm}$ alt.; ramos verdes a verde-oliva, cilíndricos a subtetrágonos, costados, glabros a pubérulos nos nós. Folhas opostas cruzadas, sésseis; lâmina verde, concolor, 0,9-2 × 0,2-1 $\mathrm{cm}$, ovada a oblongo-ovada, arredondada a cuneada na base, aguda, acuminada a mucronada no ápice, revoluta nas margens, papirácea a cartácea, glabra em ambas as faces, nervuras imersas em ambas as faces; estípulas truncadas a acuminada, ca. 0,2 mm compr. Cimeiras escorpioides, isoladas, terminais ou raramente axilares, 4 9 flores, 2-5 cm compr.; pedúnculo 0,5-3 cm compr., glabro; brácteas 3-4,5 mm compr., lanceoladas, agudas no ápice, dentículos hialinos nas margens. Flores sésseis ou pedicelo até $0,4 \mathrm{~mm}$ compr. Sépalas 4,5-5 × 0,8-1 $\mathrm{mm}$, lanceoladas, agudas no ápice, glabras a papilosas nas margens. Corola purpúrea a vinácea no tubo, lobos brancos, infundibuliforme; tubo 11-12,5 mm compr., papiloso externamente, glabro internamente; lobos 4-6,5 $\times$ 1,5-2,5 mm, ovados a ovado-lanceolados, papilosos externamente, glabros internamente. Estames inclusos; filetes 1,4-1,6 mm compr.; anteras 1,6-1,8 mm compr. Ovário 1-1,2 mm compr.; estilete 10-11,5 mm compr.; estigma filiforme. Cápsulas verde-olivas, 3,5-4 × 4-4,5 $\mathrm{mm}$; mericarpos arredondados, glabros. Carpoatlas elíptico, arredondado a truncado nas extremidades; forame circular. Sementes 10, 1-1,2 × 0,7-0,8 mm.

Endêmica do Brasil, ocorre nos estados da Bahia, Minas Gerais e Paraná (Guimarães et al. 2017). D7: 


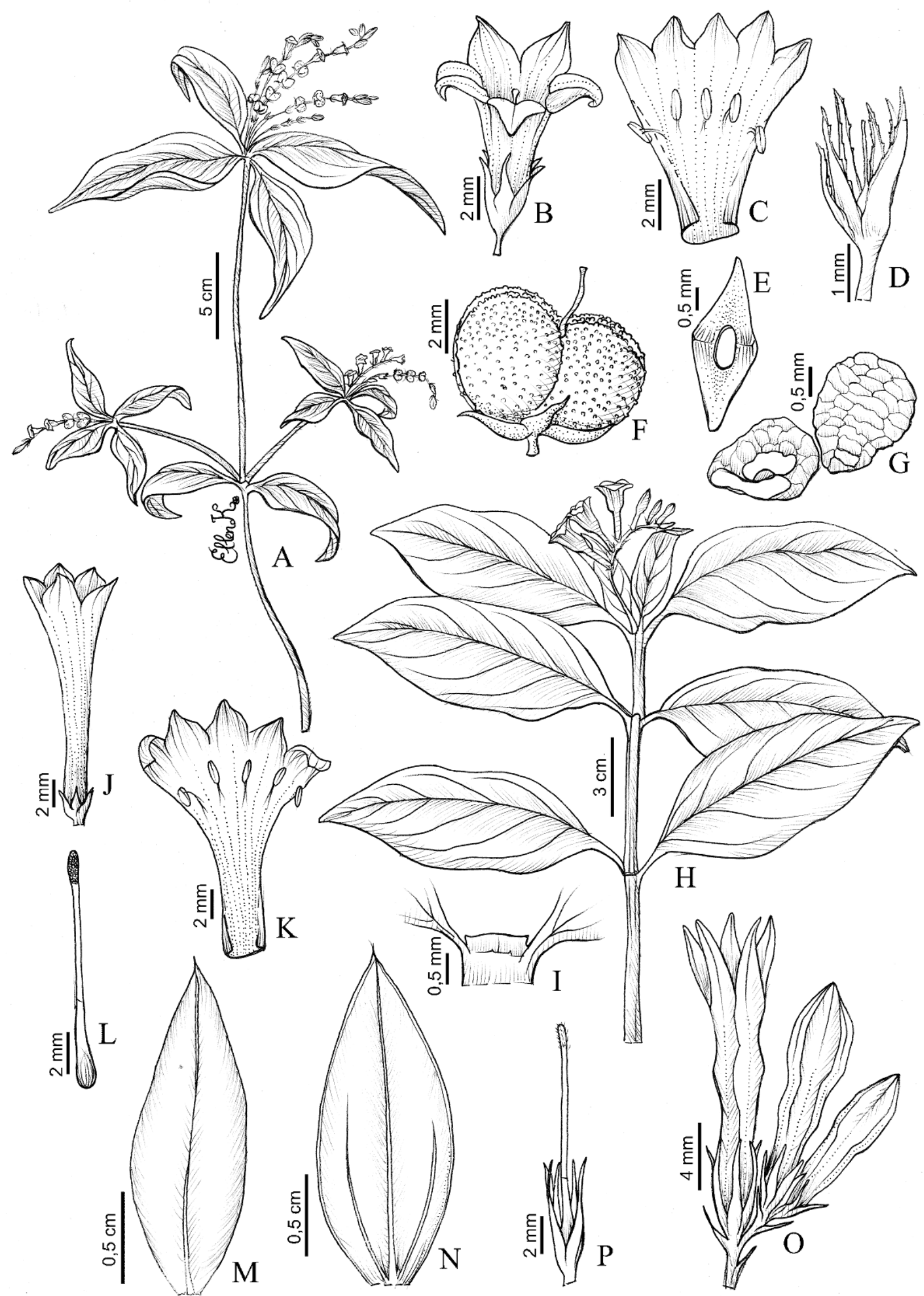

Figura 3. A-G. Spigelia anthelmia: A- ramo fértil; B- flor; C- corola aberta; D- cálice e bráctea; E- carpoatlas; F- cápsula muricadopapilosa; G- sementes, face ventral à esquerda e dorsal à direita. H-L. S. beyrichiana: H- ramo fértil; I- nó do ramo, com estípula truncada; J- flor; K- corola aberta; L- pistilo. M-P. S. blanchetiana: M- folha, face adaxial; N- folha, face abaxial; O- flor e botões; P- cálice e pistilo. (A-G- Brandão 100; H-L- Mascarenhas 29; M-P- Souza 9918). 


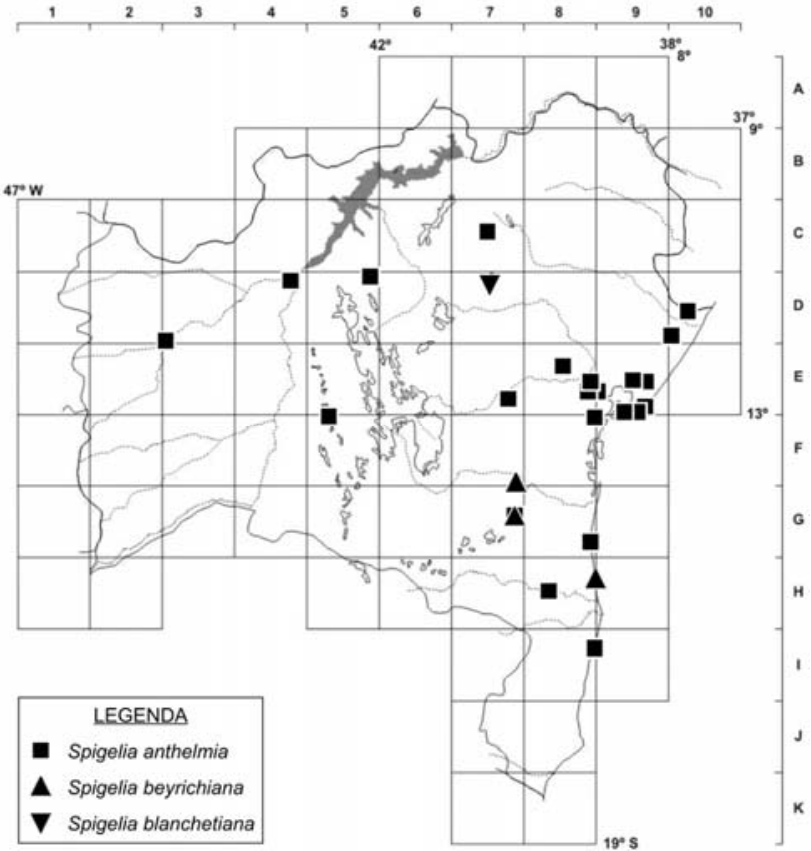

Figura 4. Mapa de distribuição de Spigelia anthelmia, S. beyrichiana e S. blanchetiana no estado da Bahia.

campos rupestres, em afloramentos areno-pedregosos, com solos litólicos ou em áreas de brejo, até $1.200 \mathrm{~m}$ de altitude.

Material examinado - Jacobina, $11^{\circ} 09^{\prime} 36^{\prime \prime} \mathrm{S}, 40^{\circ} 28^{\prime} 32^{\prime \prime} \mathrm{W}$, 1841 (fl., fr.) J.S. Blanchet 3392 (NY, foto).

Material adicional examinado - BRASIL. MINAS GERAIS: Delfinópolis, estrada para Sacramento, ca. $6 \mathrm{~km}$ de Delfinópolis, fazenda Quilombo do Rio Grande, 20¹6'19"S, 4654'55"W, 740 m s.n.m, 9 jan. 1996 (fl., fr.), V.C. Souza et al. 9918 (HUEFS).

Spigelia blanchetiana é conhecida na Bahia somente pelo material-tipo. A espécie é facilmente reconhecida pelos ramos cilíndricos a tetrágonos, costados com 4 lamelas verticais, folhas sésseis, geralmente ovadas a oblongas, com ápice agudo, mucronado, cimeiras pedunculadas, com 4 a 9 flores, e sépalas 3 vezes mais curtas que a corola.

2.4. Spigelia brachystachya Progel in Martius, Fl. Bras. 6(1): 261. 1868.

Figuras 5A, B, 6 e 30F.

Erva ereta, 20-70 cm alt.; ramos castanhos, cilíndricos a subtetrágonos, glabros. Folhas verticiladas no ápice e opostas para a base dos ramos; pecíolo ca. $3 \mathrm{~mm}$ compr.; lâmina castanha a verdeoliva, discolor, 2-10 × 1-2 cm, ovado-lanceolada a ovado-elíptica, cuneada a atenuada na base, aguda a acuminada no ápice, papirácea a membranácea, glabra em ambas as faces, 4-6 pares de nervuras secundárias; estípulas agudas a eventualmente trucadas no ápice, ca $1 \mathrm{~mm}$ compr. Cimeiras escorpioides, isoladas, terminais, 3-12 flores, 2-2,5 cm compr.; pedúnculo até $3 \mathrm{~mm}$ compr., glabro; brácteas $0,5-0,8 \mathrm{~mm}$ compr., lanceoladas, agudas no ápice, dentículos hialinos nas margens. Flores subsésseis ou pedicelo até $0,2 \mathrm{~mm}$ compr. Sépalas $2,5-3,5 \times 0,3-0,5 \mathrm{~mm}$, lanceoladas, agudas no ápice, dentículos hialinos nas margens. Corola branca, infundibuliforme; tubo $8-9 \mathrm{~mm}$ compr., glabro externa e internamente; lobos 3-4 × 2,5-3 mm, deltoides, glabros. Estames inclusos; filetes 0,4-0,6 mm compr.; anteras 1,2-1,4 mm compr. Ovário ca. 0,5 $\mathrm{mm}$ compr.; estilete até $5 \mathrm{~mm}$ compr., estigma filiforme. Cápsulas verdes, 2,6-3,6 × 5-6 mm; mericarpos arredondados, levemente agudos no ápice, muricado-papilosos. Carpoatlas rômbico, agudo nas extremidades; forame circular. Sementes $6,1,2-1,4 \times$ 0,8-1 mm.

Endêmica do Brasil, ocorre nos estados da Bahia e São Paulo (Guimarães et al. 2017). C/D7, E6 e E7: florestas ombrófilas denso-montanas e submontanas e florestas de galeria, na borda da mata, sobre solos ricos em húmus. Encontrada com flores e frutos de novembro a fevereiro e em agosto.

Material examinado - Itaberaba, $12^{\circ} 25^{\prime} 19^{\prime \prime} \mathrm{S}, 40^{\circ} 32^{\prime} 13^{\prime \prime} \mathrm{W}$, 19 ago. 2005 (fl., fr.), L.P. Queiroz 10750 (CEPEC); Jacobina,

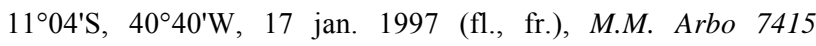
(CEPEC); Lençóis, $12^{\circ} 25^{\prime} \mathrm{S}, 4^{\circ} 27^{\prime} \mathrm{W}, 23$ nov. 1994 (fl., fr.), E. Melo 1267 (ALCB); Palmeiras, $12^{\circ} 27^{\prime} \mathrm{S}, 41^{\circ} 28^{\prime} \mathrm{W}, 4$ fev. 1995 (fl., fr.), A.M. Giulietti 1539 (ALCB); Saúde, 1100'24"S, 40²6'48"W, 12 ago. 1999 (fl., fr.), E.B. Miranda et al. 103 (HUEFS).

Spigelia brachystachya assemelha-se a S. scabra, compartilhando com ela as inflorescências geralmente sésseis e as cápsulas escabro-papilosas, diferenciandose pelos ramos cilíndricos ou mais raramente subtetrágonos devido a linhas verticais (vs. tetrágonos) e pelas folhas glabras (vs. escabras).

\subsection{Spigelia cremnophila Zappi \& E.Lucas, Kew Bull. 53(4): 981. 1998.}

Figuras 5C-H, 6 e 30G.

Erva reptante; ramos verde-vináceos, cilíndricos a subtetrágonos, costados, escabros. Folhas opostas, subsésseis ou pecíolo até $2 \mathrm{~mm}$ compr.; lâmina verde, discolor, 0,4-1,7 $\times 0,3-1,2 \mathrm{~cm}$, ovada, largo-ovada a cordiforme, cuneada a truncada na base, arredondada a aguda no ápice, revoluta nas margens, membranácea a cartácea, glabra a pubescente na face adaxial, glabra na abaxial, (1)2 pares de nervuras secundárias; estípulas largo-deltoides, eventualmente truncadas no ápice. Cimeiras escorpioides, isoladas, terminais, 1-13 flores, $1-3,7 \mathrm{~cm}$ compr.; pedúnculo até $1,5 \mathrm{~cm}$ compr., pubescente; brácteas 1,5-2,2 $\mathrm{mm}$ compr., lanceoladas, estreito-agudas no ápice, levemente papilosas nas margens. Flores subsésseis ou pedicelo até $1 \mathrm{~mm}$ compr. Sépalas 1,5-2 × 0,8-1 mm, ovado-lanceoladas a ovadas, agudas no ápice, levemente papilosas nas margens. Corola creme a esverdeada no tubo e creme nos lobos, infundibuliforme; tubo $6,9-8 \mathrm{~mm}$ compr., glabro externa e internamente; lobos 1,2-2 × 1,2-2 mm, deltoides, glabros a papilosos no ápice. Estames inclusos; filetes 1-1,3 mm compr.; anteras 1,2-1,4 mm compr. Ovário ca. $0,5 \mathrm{~mm}$ compr.; estilete $4,5-5 \mathrm{~mm}$ 
compr.; estigma filiforme. Cápsulas verdes, 2,5-3 $\times$ 3,5-4 mm; mericarpos arredondados, levemente papilosos. Carpoatlas oblongo, agudo nas extremidades; forame circular-elíptico. Sementes 6, 2-2,2 × 1-1,2 mm.

Endêmica da Bahia (Guimarães et al. 2017), é conhecida somente de Lençóis e Palmeiras, na Chapada Diamantina. E6: campos rupestres, em afloramentos rochosos ou solos pedregosos. Floresce e frutifica praticamente o ano todo.

Material selecionado - Lençóis, $12^{\circ} 27^{\prime} \mathrm{S}, 41^{\circ} 27^{\prime} \mathrm{W}, 23$ nov. 1994 (fl., fr), E. Melo et al. 1277 (CEPEC, HUEFS, UEC); Palmeiras, $12^{\circ} 28^{\prime} 12^{\prime \prime} \mathrm{S}, 41^{\circ} 25^{\prime} 59^{\prime \prime} \mathrm{W}, 9$ set. 2005 (fl., fr.), E.B. Souza et al. 1415 (HUEFS).

Spigelia cremnophila difere das demais espécies do gênero por ser uma erva reptante formando tapetes entre rochas. Apresenta estípulas truncadas a truncadoacuminadas e ampla variação em relação à lâmina foliar, que pode ser ovada, largo-ovada a cordiforme, glabra a escabra, membranácea a cartácea, com margens revolutas ou não; flores creme ou com tubo esverdeado e lobos cremes. Zappi \& Lucas (1998) já ressaltavam essas variações de textura e forma da lâmina foliar da espécie, atribuindo o fato à incidência de luz solar e regime de umidade.

\subsection{Spigelia elsieana Fern.Casas, Fontqueria 55(32):} 246. 2005.

Figuras 5I-L, 6 e $30 \mathrm{H}$.

Erva, geralmente cespitosa, 7-30 cm alt.; ramos verde-claros, cilíndricos, sulcados, glabros. Folhas opostas, sésseis; lâmina verde, discolor, 0,2-1,4 × 0,1$0,3 \mathrm{~cm}$, estreito-elíptica a elíptica, atenuada a cuneada na base, aguda a arredondada no ápice, membranácea a papirácea, glabra em ambas as faces, hifódroma; estípulas ovadas eventualmente truncadas no ápice. Cimeiras escorpioides, isoladas, terminais, 1-8 flores, 1,5-5 cm compr.; pedúnculo 0,5-4 cm compr., glabro; brácteas 1,3-3 mm compr., ovado-lanceoladas, agudas no ápice, papilosas nas margens. Flores com pedicelos 1-3 mm compr. Sépalas 1-3 × 1-1,5 mm, ovadolanceoladas, agudas no ápice, papilosas nas margens. Corola púrpura, infundibuliforme; tubo 10-12 $\mathrm{mm}$ compr., glabro externa e internamente; lobos 1-5 × 2-5 $\mathrm{mm}$, deltoides, glabros. Estames inclusos; filetes 1,5-2 mm compr.; anteras 1-1,2 mm compr. Ovário 1-1,3 mm compr.; estilete 8-9 $\mathrm{mm}$ compr.; estigma filiforme. Cápsulas verdes, 2-3 × 3-3,2 mm; mericarpos arredondados, levemente agudos no ápice, papilosos. Carpoatlas largo-elíptico, arredondado nas extremidades; forame largo-elíptico. Sementes 8-10, $1,8-2 \times 1-1,2 \mathrm{~mm}$.

Endêmica da Bahia (Guimarães et al. 2017) e restrita à região da Chapada Diamantina. E6 e F6: campos rupestres, crescendo exposta ao sol, em solos arenosos ou afloramentos rochosos. Floresce e frutifica de janeiro a maio.

Material selecionado - Abaíra, $13^{\circ} 15^{\prime} \mathrm{S}, 41^{\circ} 54^{\prime} \mathrm{W}, 31$ jan. 1992 (fl.), B. Stannard \& R.F. Queiroz 51120 (CEPEC, HUEFS); Mucugê, 1249'12"S, 41 $28^{\prime} 59^{\prime \prime} \mathrm{W}, 12$ maio 2012 (fl., fr.), A.A.
Conceição et al. 4104 (HUEFS); Palmeiras, 1242'00"S, 4131'12"W, 4 mar. 2006 (fl., fr.), A.A. Conceição 1737 (HUEFS).

Spigelia elsieana é uma erva rizomatosa, com ramos sulcados, filiforme, folhas elípticas e poucas flores rosa ou púrpura. Está geralmente associada a afloramentos rochosos, crescendo após o fogo. Apesar de ter sido erroneamente identificada como S. gracilis devido à semelhança superficial entre elas, S. elsieana no entanto, difere daquela espécie pelo seu porte menor, 7-30 cm compr. (vs. 30-70 cm compr.), as folhas elípticas (vs. estreito-elípticas a estreitooblongas), inflorescências geralmente paucifloras (1-8 vs. multifloras, 3-17 flores) e corola largoinfundibuliforme (vs. estreito-infundibuliforme).

\subsection{Spigelia flava Zappi \& Harley, Kew Bull. 47(2):} 329. 1992.

Figuras 7A-E, 8 e 30I.

Arbusto a subarbusto, $40-80 \mathrm{~cm}$ alt.; ramos castanhos, cilíndricos, estrigosos, glabros. Folhas verticiladas, subsésseis ou pecíolo até $2 \mathrm{~mm}$ compr.; lâmina verde a verde-oliva, discolor, 1-4,5 × 0,5-4,7 $\mathrm{cm}$, ovada a ovado-elíptica, cuneada na base, arredondada a aguda no ápice, espessada nas margens, subcoriácea a coriácea, glabra e nítida em ambas as faces, 4 ou 5 pares de nervuras secundárias; estípulas largo-deltoides, eventualmente truncadas no ápice, ca. $1 \mathrm{~mm}$ compr. Cimeiras congestas, capituliformes (não escorpioides), isoladas, terminais, (1)3-6 flores, 4-6 cm compr., sésseis; brácteas 0,5-1,8 mm compr., lanceoladas, agudas no ápice, papilosas nas margens. Flores com pedicelo 3-5 $\mathrm{mm}$ compr. Sépalas 5-7 $\times$ 1,2-1,5 mm compr., lanceoladas, agudas no ápice, papilosas nas margens. Corola amarela a amarelopurpurecente, infundibuliforme; tubo 25-30 $\mathrm{mm}$ compr., glabro externa e internamente; lobos 6,5-15 $\times$ 2,5-3,3 mm, lanceolados a ovado-lanceolados, glabros. Estames exsertos; filetes 6-8 mm compr.; anteras ca. 2 $\mathrm{mm}$ compr. Ovário 0,8-1 mm compr.; estilete 40-55 mm compr.; estigma capitado. Cápsulas castanhas, ca. $3 \times 4,5 \mathrm{~mm}$; mericarpos arredondados, glabros. Carpoatlas elíptico, arredondado nas extremidades; forame circular. Sementes 4, 0,5-1 × 0,5-0,8 mm.

Endêmica da Bahia (Guimarães et al. 2017) e restrita à região da Chapada Diamantina. E6 e F5/6: campos rupestres, crescendo exposta ao sol, em solos arenosos ou em afloramentos rochosos. Floresce de outubro a dezembro e frutifica em janeiro.

Material examinado - Abaíra, $13^{\circ} 22^{\prime} \mathrm{S}, 41^{\circ} 51^{\prime} \mathrm{W}, 25$ out. 1993

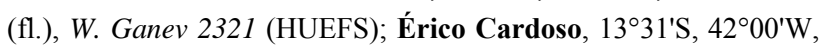
16 dez. 1988 (fl.), R.M. Harley et al. 27520 (CEPEC, HUEFS, MBM, RB); Palmeiras, $12^{\circ} 31^{\prime} \mathrm{S}, 41^{\circ} 33^{\prime} \mathrm{W}, 9$ dez. 2007 (fl.), M.L. Guedes et al. 14298 (ALCB); Rio de Contas, 13⒉ $26^{\prime} 57^{\prime \prime} \mathrm{S}$, 41 52 '57"W, 16 nov. 1996 (f1.), H.P. Bautista et al. 4371 (ALCB, CEPEC, HUEFS).

Spigelia flava é facilmente reconhecida pelo hábito subarbustivo a arbustivo, frondoso, e os ramos estrigosos, diferindo das demais espécies do gênero pelas folhas verticiladas ao longo de todo o ramo, 


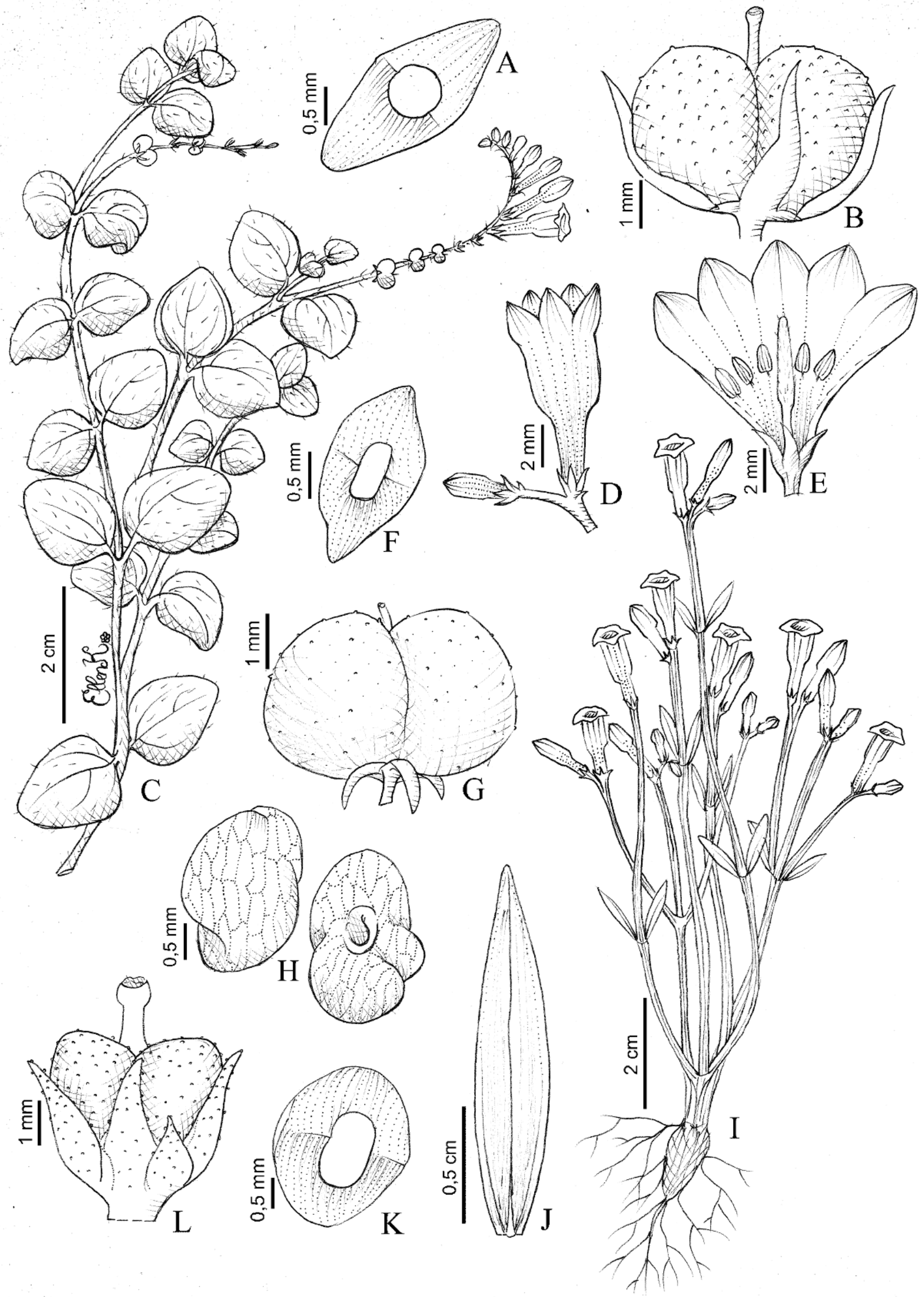

Figura 5. A, B. Spigelia brachystachya: A- carpoatlas; B- cápsula muricado-papilosa. C-H. S. cremnophila: C- ramo fértil; D- parte da cimeira com flor e botão; E- flor, com corola aberta; F- carpoatlas; G- cápsula; H- sementes, face ventral à direita e dorsal à esquerda. I-L. S. elsieana: I- planta fértil; J- folha, face adaxial; K- carpoatlas; L- cápsula e sépalas papilosas. (A, B- Noblick 1765; C-H- Brandão 124 


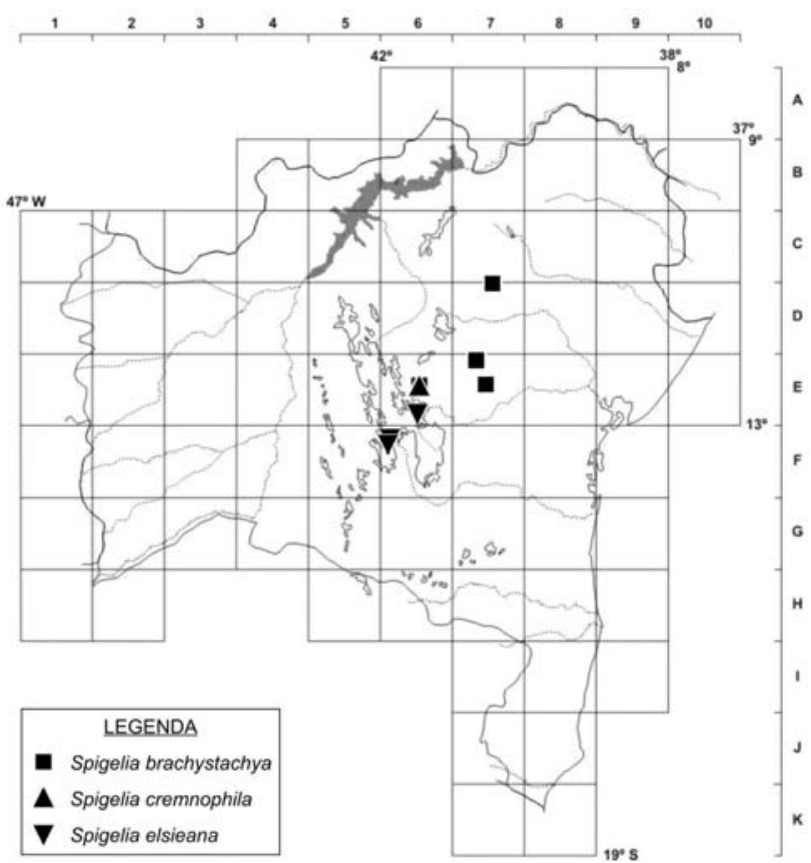

Figura 6. Mapa de distribuição de Spigelia brachystachya, S. cremnophila e S. elsieana no estado da Bahia.

subcoriáceas a coriáceas, completamente glabras. Assemelha-se a S. kuhlmannii pelo porte, textura e indumento das folhas e o tubo alongado da corola, diferindo pelas folhas elípticas a ovado-elípticas (vs. largo-ovadas), flores em cimeiras corimbiformes (vs. escorpioides), corola amarela (vs. avermelhada a púrpura), com lobos reflexos (vs. ereto), e estigma exsertos (vs. incluso).

\subsection{Spigelia flemmingiana Cham. \& Schltdl.,} Linnaea 1: 203. 1826.

Figuras 7F-H, 8 e $30 \mathrm{~J}$.

Erva ereta, ramificada, 30-100 cm alt.; ramos verde-claros, cilíndricos a subtetrágonos, costados, glabros. Folhas verticiladas no ápice e opostas para a base dos ramos; pecíolo 0,2-0,6 mm compr.; lâmina verde, discolor, 2-8,5 × 1-3 cm, oblongo-lanceolada a lanceolada, cuneada a atenuada na base, acuminada a aguda no ápice, membranácea a cartácea, escabra a raramente glabra em ambas as faces, 3-7(8) pares de nervuras secundárias; estípulas deltoides, 1-1,5 mm compr. Cimeiras escorpioides, isoladas, terminais e axilares, 8-30 flores, 2-12 cm compr.; pedúnculo até 1 cm compr., glabro; brácteas $0,5-1 \mathrm{~mm}$ compr., linearlanceoladas, agudas no ápice, dentículos hialinos nas margens. Flores sésseis ou pedicelo até $0,2 \mathrm{~mm}$ compr. Sépalas $1-1,5 \times 0,3-0,4 \mathrm{~mm}$, linear-lanceoladas, agudas no ápice, denticulada nas margens. Corola branca com guias de néctar rosa, infundibuliforme; tubo (7-)8-9 $\mathrm{mm}$ compr., glabro externa e internamente; lobos 1,5-2 $\mathrm{mm}$, ovados a deltoides, glabros. Estames inclusos; filetes ca. $1 \mathrm{~mm}$ compr.; anteras 1,2-1,5 mm compr. Ovário 0,8-1 mm compr.; estilete 7,4-9 mm compr.; estigma filiforme. Cápsulas verdes, 2,5-3 × 3,5-4 mm; mericarpos arredondados, minutamente papilosos. Carpoatlas largo-elíptico, agudo a acuminado nas extremidades; forame elíptico a largo-elíptico. Sementes 30, 2-3 × 1,5-2 mm.

Endêmica do Brasil, ocorrendo nos estados da Bahia, Espírito Santo, Minas gerais, Paraná, Pernambuco, Rio de Janeiro, Rio Grande do Sul, São Paulo, Santa Catarina e Sergipe (Guimarães et al. 2017). C7, E7, E9, E9/10, F6, F8, G5, G7, G8/9, H8, H8/9, I8/9, J8 e K8: florestas ombrófilas densosubmontanas e florestas estacionais semideciduais, em áreas preservadas ou em regeneração; em locais úmidos sombreados na borda da mata, em matas ciliares com solos humíferos. Floresce e frutifica praticamente o ano todo.

Material selecionado - Abaíra, $13^{\circ} 16^{\prime \prime} \mathrm{S}, 41^{\circ} 51^{\prime} \mathrm{W}, 22$ nov. 1991 (fl.), V.C. Souza \& C.M. Sakuragui 50271 (CEPEC, HUEFS); Alagoinhas, $12^{\circ} 07^{\prime} 01^{\prime \prime S}, 38^{\circ} 24^{\prime} 54^{\prime \prime} \mathrm{W}, 16$ maio 1984 (fl.), L.R. Noblick et al. 3213 (HUEFS); Belmonte, 1551'47"S, 38 49'40"W, 27 set. 1979 (fl.), L.A.M. Silva 608 (CEPEC, RB); Boa Nova, 14²4'41"S, 4008'20"W, 14 ago. 2013 (fl.), L.Y.S. Aona 2974 (HURB); Caetité, 1420'39"S, 42³2'16"W, 22 maio 2008 (fl.), M.L. Guedes \& F.S. Gomes 14551 (ALCB); Canavieiras, $15^{\circ} 40^{\prime} 40^{\prime \prime S}, 38^{\circ} 59^{\prime} 15^{\prime \prime} \mathrm{W}, 22$ jun. 2007 (fl., fr.), J.F.B. Pastore \& E. Suganuma 2112 (HUEFS); Cravolândia, 13²1'30"S, 3990'00"W, 29 maio 1994 (fl.), E. Melo \& F. França 1053 (CEPEC, HUEFS); Ilhéus, $14^{\circ} 37^{\prime} 20^{\prime \prime S}, 39^{\circ} 02^{\prime} 57^{\prime \prime W}, 2$ jun. 1978 (fl.), T.S. Santos 3220 (CEPEC); Itacaré, $14^{\circ} 16^{\prime} 39^{\prime \prime} \mathrm{S}, 38^{\circ} 58^{\prime} 12^{\prime \prime} \mathrm{W}, 16$ abr. 1970 (fl.), T.S. Santos 725 (CEPEC); Itamaraju, 1908'12"S, 39²1'52"W, 12 fev. 2000 (fl.), R.A.X. Borges et al. 850 (HUEFS); Itanagra, 12²2'26"S, 3758'48"W, 31 jan. 2009 (fl.), A.R.S. Prates 232 (ALCB); Mata de São João, 12³1'S, 38 16'W, 9 set. 1997 (fl.), M.L. Guedes et al. 5171 (ALCB); Mucuri, 240.'24"S, 39 40'23"W, 4 out. 2000 (fl., fr.), L.A. Silva et al. 4142 (ALCB, CEPEC, HUEFS); Pindobaçu, $10^{\circ} 39^{\prime} 42^{\prime \prime S}, 40^{\circ} 20^{\prime} 49^{\prime \prime} \mathrm{W}, 12$ abr. 2006 (fl., fr.), V.J. Santos 509 (HUEFS); Porto Seguro, 130.'27"S, 16²5'59"W, 21 mar. 1974 (fl.), R.M. Harley et al. 17241 (HUEFS);

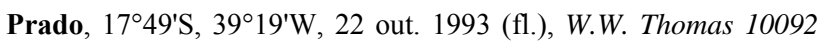
(CEPEC); Rio de Contas, 133' 13 "S, 41 ${ }^{\circ} 45^{\prime} 51^{\prime \prime} \mathrm{W}, 7$ mar. 2004 (fl.), R.M. Harley et al. 55059 (HUEFS); Ruy Barbosa, 12 ${ }^{\circ}$ 19'06"S, $40^{\circ} 29^{\prime} 26^{\prime \prime W}, 13$ nov. 2004 (fl., fr.), L.P. Queiroz et al. 9774 (HUEFS); Salvador, $12^{\circ} 58^{\prime} \mathrm{S}, 38^{\circ} 30^{\prime} \mathrm{W}, 25$ abr. 2012 (fl.), D. Oliveira et al. 7 (ALCB); Santa Cruz Cabrália, $16^{\circ} 16^{\prime} \mathrm{S}, 39^{\circ} 01^{\prime} \mathrm{W}$, 24 ago. 1994 (fl.), M.L. Guedes et al. 3449 (ALCB); Una, $15^{\circ} 55^{\prime} 58^{\prime \prime} \mathrm{S}, 39^{\circ} 45^{\prime} 10^{\prime \prime} \mathrm{W}, 26$ fev. 1978 (fl.), S.A. Mori 9308 (CEPEC); Valença, 1334'12"S, 39¹2'00"W, 1 maio 2012 (fl.), E.N. Matos et al. 3467 (HUEFS).

Spigelia flemmingiana é uma erva com ramos cilíndricos ou mais raramente subtetrágonos, com lamelas verticais, folhas oblongo-lanceoladas a lanceoladas, membranáceas a cartáceas, e inflorescências alongadas, geralmente sésseis. É ligeiramente semelhante a S. schlechtendaliana, espécie que ocorre nas Regiões Sudeste e Centro-Oeste, mas é tipicamente de florestas ombrófilas, não de campos rupestres como aquela espécie, e apresenta ramos cilíndricos a subtetrágonos (vs. tetrágonos), entrenós alongados (vs. curtos), folhas membranáceas a cartáceas, desiguais, não revolutas nas margens (vs. cartáceas, iguais e revolutas), inflorescências terminais e axilares 
(vs. apenas terminais), pedúnculo até $1 \mathrm{~cm}$ compr. (vs. maior que $2 \mathrm{~cm}$ compr.) e sépalas menores que a metade das cápsulas (vs. maiores que a metade da cápsulas).

\subsection{Spigelia fontellae Fern.Casas, Fontqueria 55(32):} 250. 2005.

Figuras 7I, J e 8.

Erva a subarbusto cespitoso, 25-30 cm alt.; ramos verdes, cilíndricos, 6-sulcados, papilosos. Folhas opostas, sésseis; lâmina verde-clara a púrpuraesverdeada, discolor, $0,15-0,3 \times 0,02-0,03 \mathrm{~cm}$, linear, truncada na base, aguda no ápice, papirácea a cartácea, papilosa em ambas as faces, hifódroma; estípulas lineares a ovadas, 0,2-0,3 $\mathrm{mm}$ compr. Cimeiras isoladas, unifloras, terminais, 4,5-5 $\mathrm{mm}$ compr.; pedúnculo até $1 \mathrm{~mm}$ compr., papiloso; brácteas ca. 0,5 mm compr., lanceoladas, agudas a acuminadas no ápice, papilosas nas margens. Flores sésseis. Sépalas verdes a purpúreas, $1-1,2 \times 0,5-0,6 \mathrm{~mm}$ compr., ovado-lanceoladas, agudas no ápice, papilosas nas margens. Corola com tubo verde-claro e lobos lilás, infundibuliforme; tubo 3-3,5 mm compr., minutamente papiloso externa e internamente; lobos $1-1,2 \times 0,8-1$ $\mathrm{mm}$, deltoide-ovados, minutamente papilosos externa e internamente. Estames inclusos; filetes $0,2-0,3 \mathrm{~mm}$ compr.; anteras $0,5-0,7 \mathrm{~mm}$ compr. Ovário 0,4-0,6 $\mathrm{mm}$ compr.; estilete 3-4 $\mathrm{mm}$ compr.; estigma filiforme. Cápsulas ca. $2 \times 2,5 \mathrm{~mm}$, mericarpos arredondados, glabros a levemente papilosos. Carpoatlas elíptico, deltoide nas extremidades; forame circular a circular-elíptico. Sementes não vistas.

Endêmica da Bahia (Guimarães et al. 2017). G5: campos rupestres, crescendo exposta ao sol, sobre solos arenosos, em áreas antropizadas, perturbadas por garimpo. Floresce e frutifica em março.

Material examinado - Licínio de Almeida, 14³2'39"S, 42³1'50"W, 12 mar. 1994 (fl., fr.), N. Roque et al. 15030 (ESA, HUEFS).

Spigelia fontellae é uma espécie ameaçada de extinção por ser conhecida apenas pelo material e localidade-tipo; foi coletada uma única vez em Licínio de Almeida, num antigo garimpo, em área prioritária para conservação. É caracterizada por ser completamente papilosa, formar densas touceiras ramificadas, com ramos filiformes, 6-sulcados, geralmente afilos, flores solitárias, terminais, de tubo esverdeado e lobos púrpura. Como as demais espécies da seção Graciles (Progel 1868), é caracterizada pelos ramos costado-tetrágonos a sulcados, folhas lineares, sépalas menores que a metade do comprimento da cápsula e anteras inclusas (exceto em S. pulchella).

\subsection{Spigelia genuflexa Popovkin \& Struwe, PhytoKeys 6: 49. 2011.}

Figuras $7 \mathrm{~K}-\mathrm{N}, 9$ e $30 \mathrm{~K}$.

Erva ereta, 2-25 cm alt.; ramos verde-escuros a púrpura, cilíndricos, 6- a 8-sulcados, papilosos. Folhas verticiladas no ápice e opostas para a base dos ramos; pecíolos até $2 \mathrm{~mm}$ compr.; lâmina verde-escura, discolor, $(0,3) 0,6-5 \times(0,2) 0,3-1,2 \quad \mathrm{~cm}$ compr., lanceolada a ovada, atenuada a cuneada na base, acuminada a aguda no ápice, papiráceas a cartácea, escabra adaxialmente, glabra abaxialmente, (2-)4 pares de nervuras secundárias, visíveis apenas na face abaxial; estípulas deltoides, 0,3-0,5 $\mathrm{mm}$ compr. Cimeiras escorpioides, isoladas ou em pares, terminais e/ou axilares, 1-9 flores, 1-4,5 cm compr.; pedúnculo até $2 \mathrm{~cm}$ compr., glabro; brácteas $0,8-1 \mathrm{~mm}$ compr., lanceoladas, agudas a acuminadas no ápice, papilosas nas margens. Flores com pedicelo 0,5-2,5 mm compr. Sépalas $1,5-2 \times 0,3-0,5 \mathrm{~mm}$, lanceoladas a ovadolanceoladas, agudas no ápice, papilosas nas margens. Corola creme com margem púrpura, infundibuliforme; tubo 5-6,8 $\mathrm{mm}$ compr., glabro externa e internamente; lobos 1,3-2 × 1,2-2 mm, deltoides, glabros externa e internamente. Estames inclusos; filetes ca. $1 \mathrm{~mm}$ compr.; anteras 1-1,2 mm compr. Ovário 0,2-0,5 mm compr.; estilete ca. $6,8 \mathrm{~mm}$ compr.; estigma filiforme. Cápsulas verdes, 2-2,5 × 2,5-3 $\mathrm{mm}$; mericarpos arredondados, glabros a esparso-escabros. Carpoatlas rômbico, agudo nas extremidades; forame oblongo. Sementes 12 , ca. $1 \times 0,5-0,8 \mathrm{~mm}$.

Endêmica da Bahia (Guimarães et al. 2017). E9/10: florestas ombrófilas denso-montanas e submontanas, crescendo no interior da mata, sobre solos ricos em húmus. Foi encontrada com flores e frutos em junho.

Material examinado - Entre Rios, $12^{\circ} 03^{\prime} \mathrm{S}, 38^{\circ} 00^{\prime} \mathrm{W}, 12$ jun. 2013 (fl., fr.), A.V. Popovkin \& J.C. Mendes 1464 (HUEFS).

Spigelia genuflexa caracteriza-se pelo porte pequeno (2-25 cm alt.), ramos com 6 a 8 sulcos papilosos, folhas lanceoladas a ovadas, escabras, principalmente nas margens. É facilmente reconhecida por apresentar frutos geocárpicos, daí seu epíteto específico. Trata-se de uma espécie ameaçada de extinção, por ser conhecida apenas da localidade-tipo. Segundo Popovkin et al. (2011), a espécie é similar a $S$. flemmingiana, diferindo pelo porte reduzido (até $25 \mathrm{~cm}$ vs. 30-100 cm alt.), corola maior $(6,3-8,8 \mathrm{~mm}$ vs. $9,5-$ $11 \mathrm{~mm}$ compr.) e inflorescências com menos flores (19 vs. 8-30).

\subsection{Spigelia gracilis A.DC. in A.P. de Candolle,} Prodr. 9: 6. 1845.

Figuras 9, 10A-E e 30L.

Erva ereta a subarbusto cespitoso, $30-50 \mathrm{~cm}$ alt.; ramos verdes, cilíndricos, 10-sulcados, glabros. Folhas opostas, sésseis; lâmina verde, concolor, 1,5-3(-4,5) × 0,1-0,2 cm compr., estreito-elíptica a estreito-oblonga, atenuada na base, aguda a arredondada no ápice, revoluta nas margens, membranácea a papirácea, escabra na face adaxial, glabra na abaxial, hifódroma; estípulas lineares. Cimeiras escorpioides, isoladas, terminais, (1)3-17 flores, 1,5-6 mm compr.; pedúnculo 1-4,5 cm, glabro; brácteas 1-2 $\mathrm{mm}$ compr., lanceoladas, agudas a acuminadas no ápice, papilosas nas margens. Flores com pedicelo $1-1,5 \mathrm{~mm}$ compr. Sépalas 2,2-2,8 ×0,3-0,8 mm, lanceoladas, agudas no ápice, papilosas nas margens. Corola branco- 


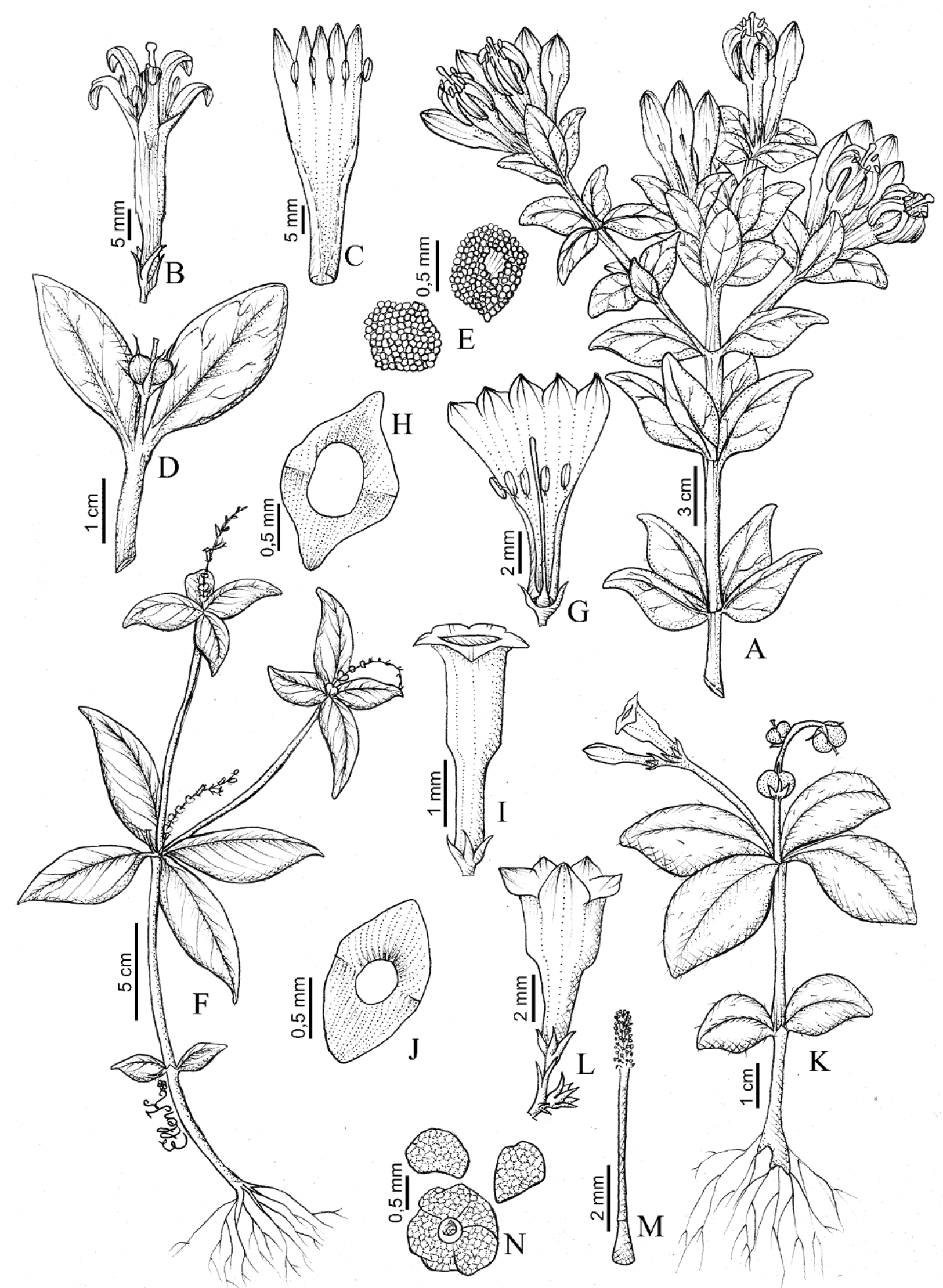

Figura 7. A-E. Spigelia flava: A- ramo fértil; B- flor; C- corola aberta; D- parte apical do ramo com cápsula; E- sementes, face ventral à direita e dorsal à esquerda. F-H. S. flemmingiana: F- planta fértil; G- flor com parte do cálice removido e corola aberta; H- carpoatlas. I, J. S. fontellae: I- flor; J- carpoatlas. K-N. S. genuflexa: K- planta fértil; L- flor; M- pistilo; N- sementes, unidas pela placenta, face ventral (abaixo) e sementes isoladas, face dorsal (acima). (A-C- Bautista 4371; D, E- Miranda 990; F-H- Queiroz 9774; I, J- Roque 15030; K-N- Popovkin 703). 


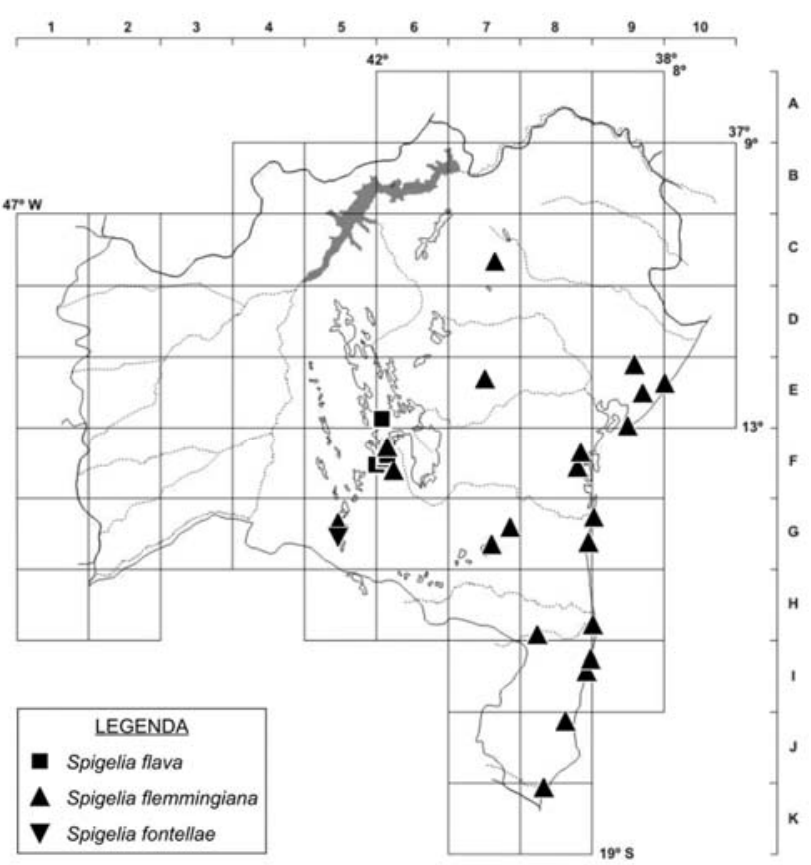

Figura 8. Mapa de distribuição de Spigelia flava, S. flemmingiana e S. fontellae no estado da Bahia.

esverdeada com guias de néctar rosa, infundibuliforme; tubo 12,5-14 $\mathrm{mm}$ compr., glabro externa e internamente; lobos $3-3,5 \times 2-3 \mathrm{~mm}$, deltoides, glabros externa e internamente. Estames inclusos; filetes ca. $2 \mathrm{~mm}$ compr.; anteras $1,8-2 \mathrm{~mm}$ compr. Ovário 0,5-1 mm compr.; estilete $8-13 \mathrm{~mm}$ compr.; estigma filiforme. Cápsulas 2-2,5 $\times 3-3,5 \mathrm{~mm}$; mericarpos arredondados, glabros ou papilosos. Carpoatlas largo-elíptico, agudo-arredondado nas extremidades; forame elíptico a oblongo-elíptico. Sementes 12, 1-1,2 × 0,8-1 mm.

Endêmica do Brasil, encontrada na Bahia e em Minas Gerais (Guimarães et al. 2017). C6, C7, C/D8, D6, D6/7, D7, E6, F6 e G6: campos rupestres, em afloramentos rochosos e solos areno-pedregosos. Floresce e frutifica praticamente o ano todo.

Material selecionado - Campo Formoso, 14\% $43^{\prime} 45^{\prime \prime} \mathrm{S}$, $41^{\circ} 16^{\prime} 00^{\prime \prime} \mathrm{W}$, abr. 1994 (fl.), M. Sobral et al. 7630 (HUEFS, MBM); Jacobina, $12^{\circ} 04^{\prime} 12^{\prime \prime} \mathrm{S}, 40^{\circ} 40^{\prime} 12^{\prime \prime} \mathrm{W}, 13$ abr. 1999 (fl.), L.P. Queiroz

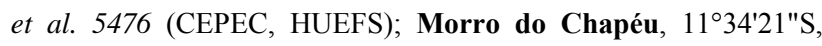
41 ${ }^{\circ} 10^{\prime} 50^{\prime \prime} \mathrm{W}, 19$ abr. 2001 (fl.), E. Melo et al. 3330 (HUEFS); Mucugê, $12^{\circ} 05^{\prime} 00^{\prime \prime S}, 41^{\circ} 29^{\prime} 20^{\prime \prime} \mathrm{W}, 6$ abr. 2003 (fl.), A.M. Giulietti

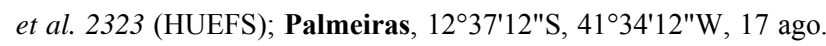
2008 (fl.), P.D. Carvalho \& A.A. Conçeição 410 (HUEFS); Piatã, $13^{\circ} 18^{\prime} 42^{\prime \prime S}, 41^{\circ} 33^{\prime} 45^{\prime \prime} \mathrm{W}, 8$ jan. 2006 (fl., fr.), T.S. Nunes et al. 1445 (HUEFS); Saúde, 1056'33"S, 40²4'25"W, 15 maio 1999 (fl., fr.), F. França et al. 2952 (HUEFS); Senhor do Bonfim, 10²2'36"S, $40^{\circ} 12^{\prime} 21 " \mathrm{~W}, 12$ jul. 2005 (fl., fr.), D. Cardoso et al. 672 (HUEFS); Sento Sé, $10^{\circ} 24^{\prime} 00^{\prime \prime} \mathrm{S}, 41^{\circ} 49^{\prime} 59^{\prime \prime} \mathrm{W}, 12$ jul. 2005 (fl.), R.M. Harley 16786 (CEPEC); Umburanas, $10^{\circ} 21^{\prime} 00^{\prime \prime} \mathrm{S}, 41^{\circ} 13^{\prime} 12^{\prime \prime} \mathrm{W}, 11$ abr. 1999 (fl.), L.P. Queiroz et al. 5358 (HUEFS).

Spigelia gracilis é semelhante às outras espécies da seção Graciles. É caracterizada por apresentar folhas escabras na face adaxial, margens revolutas e sépalas diminutas em relação ao tamanho da corola.
Assemelha-se especialmente a $S$. linarioides e $S$. spartioides, diferindo de ambas pelos ramos sulcados e glabros (vs. papilosos em S. linarioides e tetrágonos em S. spartioides). Ainda assim, essas espécies são de difícil delimitação, apresentando grande sobreposição morfológica. Estudos populacionais detalhados poderão, então, auxiliar no entendimento das relações entre elas.

2.12. Spigelia kuhlmannii E.F.Guim. \& Fontella, Ci. \& Cult. 27(10): 1124. 1975.

Figuras $9,10 \mathrm{~F}-\mathrm{L}$ e $30 \mathrm{M}, \mathrm{N}$.

Subarbusto a arbusto, $50-150 \mathrm{~cm}$ alt.; ramos castanhos a verdes, cilíndricos, glabros. Folhas opostas; pecíolo 3-6 $\mathrm{mm}$ compr.; lâmina verde, discolor, 1-5 × 1-6 cm, largo-ovada, truncada a subcordada na base, obtusa a arredondada no ápice, levemente revoluta e espessada nas margens, subcoriácea, glabra a escabra em ambas as faces, 4 ou 5 pares de nervuras secundárias; estípulas truncadas no ápice. Cimeiras escorpioides, isoladas ou em grupos de 2-4, terminais, 3-11 flores, 2,5-5,5 cm compr.; pedúnculo até $5 \mathrm{~mm}$ compr., escabro; brácteas 4-6,5 $\mathrm{mm}$ compr., lanceoladas a linear-lanceoladas, agudas a acuminadas no ápice, papilosas nas margens. Flores com pedicelo até $2 \mathrm{~mm}$ compr. Sépalas 5-9 $91-1,5$ $\mathrm{mm}$, lanceoladas a linear-lanceoladas, papilosas nas margens. Corola púrpura com lobos creme, infundibuliforme; tubo $30-33 \mathrm{~mm}$ compr., glabro externa e internamente; lobos 3-3,5 × 2,8-3 mm, deltoides, glabros externa e internamente. Estames inclusos; filetes 1-1,5 mm compr.; anteras $2,8-3 \mathrm{~mm}$ compr. Ovário 1-1,5 mm compr.; estilete $20-25 \mathrm{~mm}$ compr.; estigma capitado. Cápsulas verdes a castanhoesverdeadas, 4-5 × 6-8 $\mathrm{mm}$; mericarpos arredondados, muricado-papilosos. Carpoatlas largo-elíptico, agudo nas extremidades; forame elíptico a largo-oblongo. Sementes 10, 2-3 × 1,5-2 mm.

Endêmica da Bahia (Guimarães et al. 2017). C7, D6/7 e E7: campos rupestres, eventualmente em transição para o cerrado, crescendo exposta ao sol, em afloramentos rochosos ou solos arenosos. Floresce e frutifica de junho a agosto e em novembro.

Material selecionado - Jacobina, $11^{\circ} 14^{\prime} 27^{\prime \prime S}, 40^{\circ} 57^{\prime} 00^{\prime \prime} \mathrm{W}, 19$ nov. 2011 (fl., fr.), N. Roque 3428 (ALCB); Jaguarari, 1707'48"S, $40^{\circ} 13^{\prime} 12^{\prime \prime W}, 25$ jun. 2005 (fl., fr.), R.F. Souza-Silva \& A. Rapini 30 (HUEFS); Miguel Calmon, $11^{\circ} 19^{\prime} 59^{\prime \prime} \mathrm{S}, 40^{\circ} 10^{\prime} 12^{\prime \prime} \mathrm{W}, 2$ ago. 2006 (fl.,fr.), M.L. Guedes et al. 12169 (ALCB); Ruy Barbosa, $12^{\circ} 18^{\prime} 21^{\prime \prime S}, 40^{\circ} 28^{\prime} 32^{\prime \prime} \mathrm{W}, 28$ jul. 2004 (fl., fr.), L.P. Queiroz et al. 9354 (HUEFS); Senhor do Bonfim, 10²2'14"S, 40¹2'19"W, 27 jul. 2005 (fl., fr.), E.B. Souza et al. 1389 (HUEFS).

Spigelia kuhlmannii é bastante peculiar por se tratar de um subarbusto de folhas coriáceas, largo-ovadas, com ápice arredondado e margens espessadas, completamente glabra, ou raramente escabra quando jovem, inflorescências com flores bastante chamativas, avermelhadas a púrpura, brácteadas, e perianto bastante desenvolvido em relação às demais espécies de Spigelia. Assemelha-se a S. flava pelo porte arbustivo, 


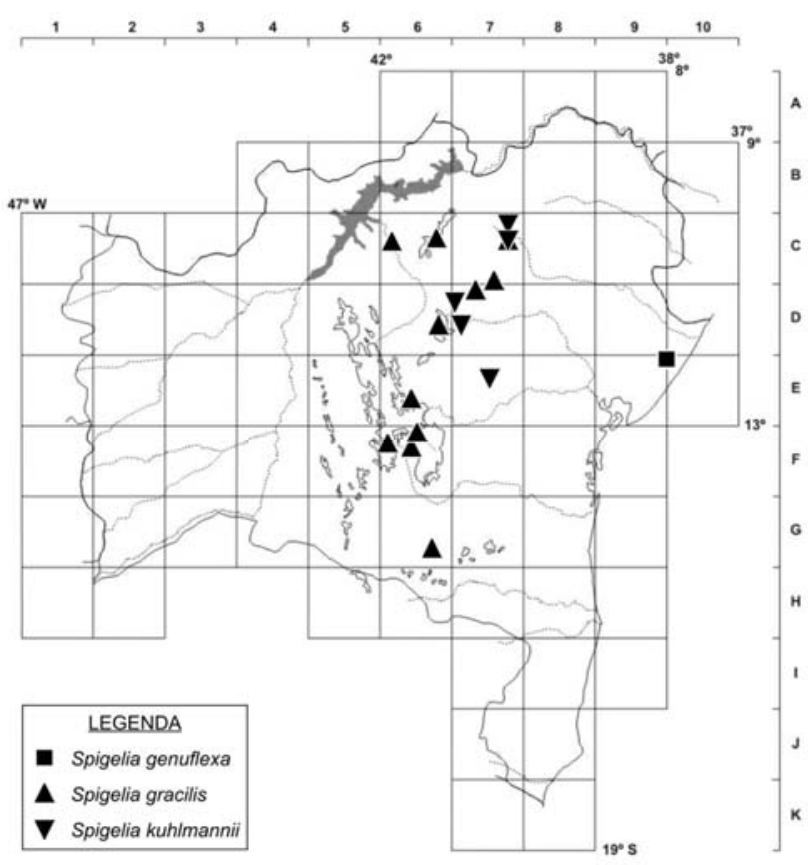

Figura 9. Mapa de distribuição de Spigelia genuflexa, S. gracilis e S. kuhlmannii no estado da Bahia.

diferindo pelas folhas opostas (vs. verticiladas), corola púrpura (vs. amarela), com lobos mais curtos (3-3,5 mm vs. 6,5-15 mm compr.) e eretos (vs. reflexos).

\subsection{Spigelia laurina Cham. \& Schltdl., Linnaea 1: 204. 1826.}

Figuras $10 \mathrm{M}-\mathrm{P}, 11$ e $30 \mathrm{O}$.

Erva, raramente subarbusto, $30-60 \mathrm{~cm}$ alt.; ramos verdes, cilíndricos, glabros. Folhas verticiladas no ápice e opostas para a base dos ramos; pecíolo até $1 \mathrm{~cm}$ compr.; lâmina verde, púrpura a negrejante quando seca, discolor, 3-13 × 0,5-3,2 cm, lanceolada, ovado-lanceolada a oblonga, atenuada na base, acuminada a aguda no ápice, levemente revoluta ou não nas margens, membranácea a papirácea, glabra em ambas as faces, 5-7(9) pares de nervuras secundárias; estípulas inconspícuas, deltoides, 1-2 mm compr. Cimeiras escorpioides, isoladas ou em grupos de até 11, terminais e axilares, 3-15 flores, 5-15 cm compr.; pedúnculo 4-9 $\mathrm{cm}$ compr., glabro; brácteas ca. $0,5 \mathrm{~mm}$ compr., lanceoladas a ovadas, agudas no ápice, glabras nas margens. Flores com pedicelo até 1 $\mathrm{mm}$ compr. Sépalas $1,2-1,8 \times 0,4-0,6 \mathrm{~mm}$, lanceoladas, glabras nas margens. Corola branca, eventualmente com guias de néctar rosa, ou toda rosa, infundibuliforme; tubo 12-17 mm compr., glabro externa e internamente; lobos 3-4 $\times 2-3 \mathrm{~mm}$, deltoides a ovado-deltoides, glabros. Estames inclusos; filetes 1-1,2 mm compr.; anteras 1,8-2 mm compr. Ovário 0,8-1,2 mm compr.; estilete 13-17 mm compr.; estigma filiforme. Cápsulas verdes, 3-3,5 $\times$ 5-6 mm; mericarpos agudos, glabros. Carpoatlas largamente oblongo-elíptico, truncado, retuso a arredondado nas extremidades; forame oblongo a arredondado. Sementes 6, 2-2,2 × 1,2-1,5 mm.

Endêmica do Brasil, ocorre na Bahia, Espírito Santo e Rio de Janeiro (Guimarães et al. 2017). C7, E6, E8,
F8, G7, G8, H8, I8 e J8: florestas ombrófilas densomontanas e submontanas, crescendo à sombra, sobre solos arenosos, ricos em húmus. Floresce e frutifica durante $o$ ano todo.

Material selecionado - Amargosa, $13^{\circ} 10^{\prime} 12^{\prime \prime} \mathrm{S}, 39^{\circ} 30^{\prime} 00^{\prime \prime} \mathrm{W}$, 17 mar. 2007 (fl., fr.), J.L. Paixão et al. 1111 (CEPEC, HUEFS); Andaraí, 1251'39"S, 41 $58^{\circ} 19^{\prime \prime} \mathrm{W}, 6$ dez. 2007 (fl., fr.), M.L.

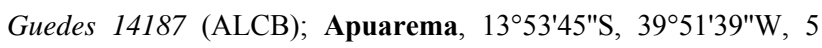
mar. 2013 (fl., fr.), L.Y.S. Aona et al. 2241 (HUEFS, HURB); Belmonte, $15^{\circ} 51^{\prime} 47^{\prime \prime} \mathrm{S}, 38^{\circ} 49^{\prime} 40^{\prime \prime} \mathrm{W}, 17$ abr. 1975 (fl., fr.), T.S. Santos 2967 (CEPEC, RB); Boa Nova, 14²4'36"S, 40¹7'09"W, 6 jan. 2013 (fl., fr.), L.Y.S. Aona et al. 2047 (HURB, RB); Camacan, 15²3'30"S, 39³5'49"W, 13 fev. 2005 (fl., fr.), A. Jardim et al. 4457 (HUEFS); Elísio Medrado, 1255'59"S, 39¹0'12"W, 19 out. 2013 (fl., fr.), M.L. Guede et al. 21053 (ALCB); Eunápolis, $16^{\circ} 22^{\prime} 39^{\prime \prime S}, 39^{\circ} 34^{\prime} 49^{\prime \prime W}, 7$ jul. 1970 (fl., fr.), T.S. Santos 914 (CEPEC); Gandu, 134' $38^{\prime \prime} \mathrm{S}, 39^{\circ} 29^{\prime} 12^{\prime \prime} \mathrm{W}, 22$ out. 1970 (fl., fr.), T.S. Santos 1177 (CEPEC, RB); Ibirapitanga, 1409'31"S, 39²2'24"W, 26 abr. 2013 (fl., fr.), A.O. Matos 56 (HUEFS); Ilhéus, 14²7'20"S, 39²9'38"W, 17 fev. 1982 (fl., fr.), L.A.M. Silva et al. 1544 (CEPEC, HUEFS, MBM); Ipiaú, 140ํ'19"S, 3944'20"W, 30 out. 1970 (fl., fr.), T.S. Santos 1234 (CEPEC, RB); Itabuna, $14^{\circ} 15^{\prime} 00^{\prime \prime S}, 39^{\circ} 10^{\prime} 12^{\prime \prime W}, 1$ abr. 1974 (fl., fr.), R.M. Harley 17606 (CEPEC); Itacaré, 14¹9'50"S, 39³4'09"W, 20 abr. 2008 (fl., fr.), J.G. Jardim 5218 (CEPEC); Itagibá, 14²10'53"S, 3945'00"W, 29 maio 2008 (fl., fr.), C.H.A. Ramos \& L.J. Alves 190 (ALCB); Itapé, 14 53'53"S, 39²5'15"W, 7 jan. 1969 (fl., fr.), J. Almeida 352 (HUEFS); Ituberá, 1341'49"S, 3909'30"W, 10 abr. 2006 (fl., fr.), R.M. Valadão \& L.M. Guedes 442 (ALCB); Lençóis, 12²7'S, 41 ${ }^{\circ} 27^{\prime} \mathrm{W}, 22$ maio 1980 (fl., fr.), R.M. Harley 22392 (CEPEC, RB); Maraú, $14^{\circ} 40^{\prime} 12^{\prime \prime S}, 39^{\circ} 00^{\prime} 00^{\prime \prime} \mathrm{W}, 15$ maio 1980 (fl., fr.), R.M. Harley 22114 (CEPEC, RB); Morro do Chapéu, 1109'20"S, 41 $07^{\prime} 00^{\prime \prime W}, 30$ abr. 2015 (fl., fr.), E.K.S. Brandão et al. 104 (HUEFS); Porto Seguro, 1649'59"S, 39¹0'12"W, 12 jan. 1977 (fl., fr.), R.M. Harley 17877 (CEPEC); Santa Cruz Cabrália, 16 $49^{\prime} \mathrm{S}, 39^{\circ} 19^{\prime} \mathrm{W}, 9$ fev. 1984 (fl., fr.), F.S. Santos 243 (CEPEC); Senhor do Bonfim, $10^{\circ} 18^{\prime} \mathrm{S}, 40^{\circ} 15^{\prime \prime} \mathrm{W}, 1$ mar. 1974 (fl., fr.), R.M. Harley 16591 (CEPEC); Ubirataia, 13 ${ }^{\circ} 54^{\prime} 50^{\prime \prime} \mathrm{S}, 39^{\circ} 52^{\prime} 30^{\prime \prime} \mathrm{W}, 20$ jul. 2013 (fl., fr.), L.Y.S. Aona et al. 2857 (HURB); Una, $15^{\circ} 18^{\prime} 20^{\prime \prime S}, 39^{\circ} 15^{\prime} 00^{\prime \prime W}, 16$ out. 2011 (fl., fr.), E.N. Matos et al. 690 (HUEFS); Uruçuca, 14 $51^{\prime} 00^{\prime \prime S}, 39^{\circ} 11^{\prime} 39^{\prime \prime} \mathrm{W}, 27$ jul. 2000 (fl., fr.), J.G. Jardim et al. 3081 (HUEFS); Valença, 13²4'10"S, 39॰43'51"W, 12 ago. 1980 (fl., fr.), L.A.M. Silva 1033 (CEPEC); Wenceslau Guimarães, $13^{\circ} 45^{\prime} 20^{\prime \prime}$ S, 39 $42^{\circ} 55^{\prime \prime} \mathrm{W}, 15$ out. 2012 (fl., fr.), D.C. Zappi et al. 3454 (HURB).

Spigelia laurina varia bastante, principalmente quanto à forma das folhas, sendo semelhante a $S$. beyrichiana. Segundo a descrição original, S. laurina caracteriza-se principalmente pelos ramos cilíndricos e sépalas cerca de 10 vezes mais curtas que a corola. Além disso, as cimeiras aparecem geralmente em grupos de 3 a 11 (vs. 1 ou raramente 3), terminais e axilares (vs. apenas terminais), e, principalmente, pelo pedúnculo de 3-9 $\mathrm{cm}$ compr. (vs. até $2 \mathrm{~cm}$ ). As duas espécies ocorrem simpatricamente, no interior de matas úmidas, e apresentam características que se sobrepõem, ressaltando a necessidade de estudos populacionais para esclarecer com precisão a delimitação entre elas. 


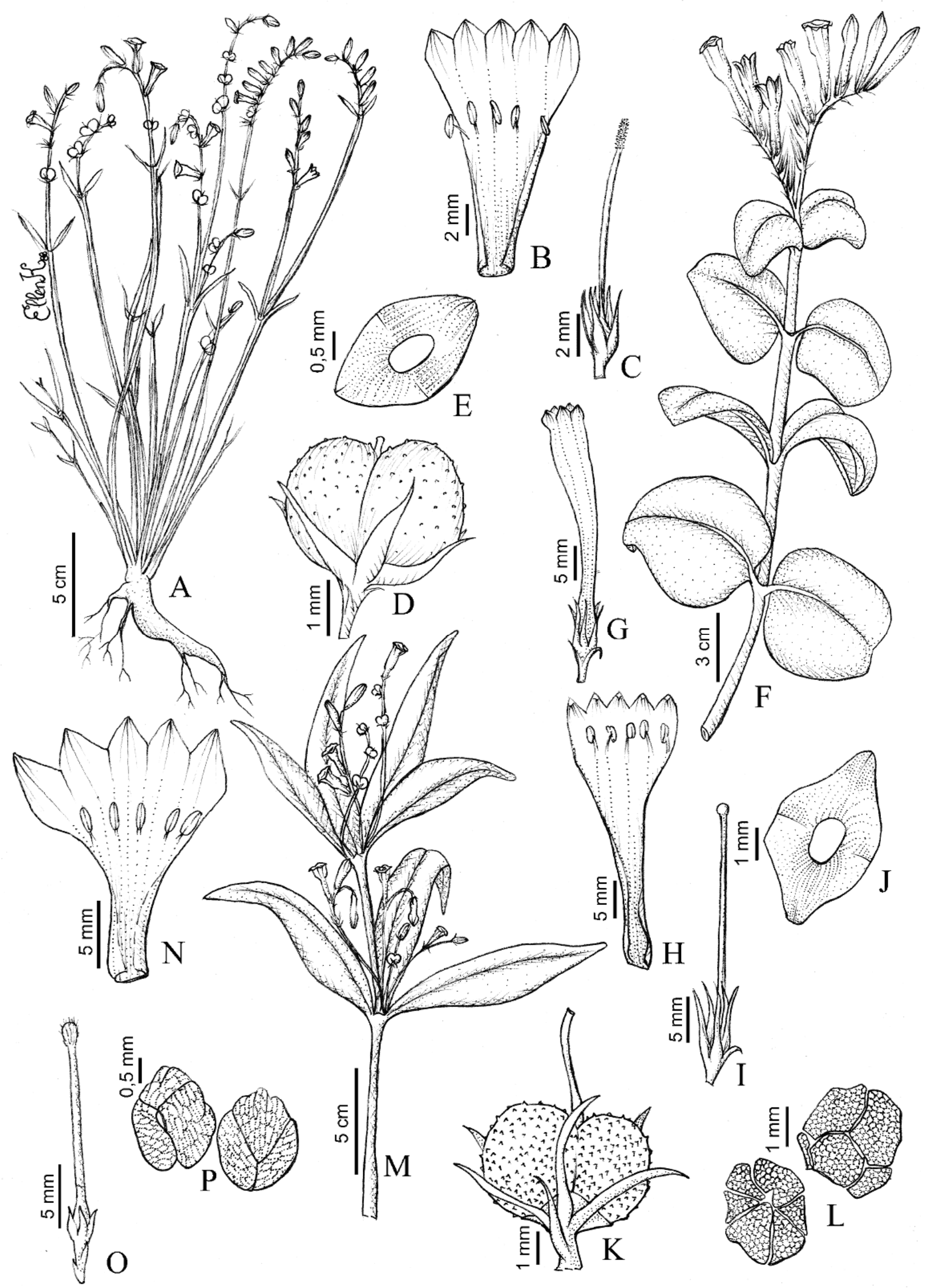

Figura 10. A-E. Spigelia gracilis: A- planta fértil; B- corola aberta; C- cálice e pistilo; D- cápsula papilosa; E- carpoatlas. F-L. S. kuhlmanii: F- ramo fértil; G- flor; H- corola aberta; I- cálice e pistilo; J- carpoatlas; K- cápsula muricado-papilosa; L- sementes unidas pela placenta, face ventral à esqueda e dorsal à direita. M-P. S. laurina: M- planta fértil; N- corola aberta; O- cálice e pistilo; P- sementes unidas pela placenta, face ventral à esquerda e dorsal à direita. (A-E- Furtado 1486; F-L- Nunes 1185; M-O- Matos 3531; P- Paixão 1111). 
2.14. Spigelia linarioides A.DC. in A.P. de Candolle, Prodr. 9: 6. 1845.

Figuras 11, 12A-D e 31A.

Erva ereta, cespitosa, $30-50 \mathrm{~cm}$ alt.; ramos verdes, cilíndricos, 6-sulcados, escabriúscula nas costelas. Folhas opostas, sésseis; lâmina verde-clara, discolor, $0,5-2,5(3) \times 0,1-0,3 \mathrm{~cm}$, linear, truncada na base, acuminada no ápice, revoluta nas margens, cartácea, escabra na face adaxial, glabra na abaxial, hifódroma; estípulas lineares. Cimeiras escorpioides, isoladas, terminais, (4)8-18 flores, $2-7 \mathrm{~cm}$ compr.; pedúnculo 0,7-4 cm compr., glabro; brácteas ca. $2 \mathrm{~mm}$ compr., estreito-lanceoladas, acuminadas no ápice, denticuladas nas margens. Flores com pedicelo $0,1-0,4 \mathrm{~mm}$ compr. Sépalas 2-3 × 0,8-0,9 mm, lanceoladas, acuminadas no ápice, denticuladas nas margens. Corola branca com lobos rosa a completamente rosa, infundibuliforme; tubo 7-9,5 mm compr., papiloso externamente, glabro internamente; lobos $2-3 \times 2-2,5 \mathrm{~mm}$, deltoide-ovados a ovados, glabros interna e externamente. Estames inclusos; filetes $0,8-1 \mathrm{~mm}$ compr.; anteras $1,5-1,8 \mathrm{~mm}$ compr. Ovário $0,8-1 \mathrm{~mm}$ compr.; estilete $0,8-13 \mathrm{~mm}$ compr.; estigma filiforme. Cápsulas verdes, 1,5-3 $\times$ 2-4 $\mathrm{mm}$; mericarpos arredondados, minutamente papilosos. Carpoatlas largo-elíptico, deltoide nas extremidades; forame elíptico. Sementes $16,1,5-2 \times$ $1,5-1,8 \mathrm{~mm}$.

Endêmica do Brasil, ocorre na Bahia, Pernambuco, Mato Grosso e Minas Gerais (Guimarães et al. 2017). C6, C7, C/D7, D7, F5 e F6: campos rupestres, em afloramentos rochosos ou solos arenosos. Floresce e frutifica praticamente $\mathrm{o}$ ano todo.

Material selecionado - Jacobina, $11^{\circ} 12^{\prime} 12^{\prime \prime} \mathrm{S}, 40^{\circ} 30^{\prime} 27^{\prime \prime} \mathrm{W}, 30$ dez. 2004 (fl.), R. Mello-Silva \& R.C. Forzza 2812 (HUEFS, RB);

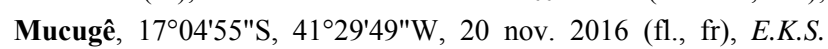
Brandão et al. 111 (HUEFS); Piatã, $11^{\circ} 01^{\prime} \mathrm{S}, 41^{\circ} 52^{\prime} \mathrm{W}, 19$ jan. 2006

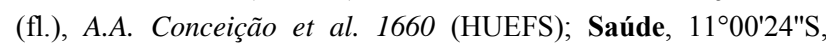
40²6'48"W, 12 ago. 1999 (fl., fr.), E.B. Miranda et al. 109 (HUEFS); Senhor do Bonfim, 10²2'26"S, 40¹2'26"W, 27 jul. 2005 (fl.), E.B. Souza et al. 1379 (HUEFS); Sento Sé, 10²4'S,

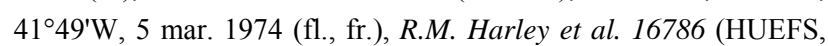
RB, UEC); Umburanas, 10²2'12"S, 4119'12"W, 12 abr. 1999 (fl., fr.), L.P. Queiroz et al. 5461 (HUEFS).

Spigelia linarioides é uma erva de pequeno porte, com ramos sulcados e folhas e flores reduzidas. Assemelha-se a $S$. fontellae por formar touceira e pelas folhas lineares, porém é maior $(30-50 \mathrm{~cm}$ vs menor que $30 \mathrm{~cm}$ alt.), suas folhas são maiores $(0,5-2,5 \times$ $0,1-0,3$ vs. $0,15-0,3 \times 0,02-0,03 \mathrm{~cm})$, as cimeiras escorpioides, com 4-18 flores (vs. reduzidas a uma flor solitária), e a corola também é maior (9-11 mm vs. 4$4.5 \mathrm{~mm}$ compr.).

2.15. Spigelia martiana Cham., Linnaea 8: 15. 1833. Figuras 11 e 12E.

Erva ramificada até $50 \mathrm{~cm}$ alt.; ramos verdes, cilíndricos a subtetrágonos, 4-costados, escabros. Folhas opostas, sésseis a subsésseis; lâmina verde, discolor, $0,8-3 \times 0,1-0,5 \mathrm{~cm}$, lanceolada, truncada a

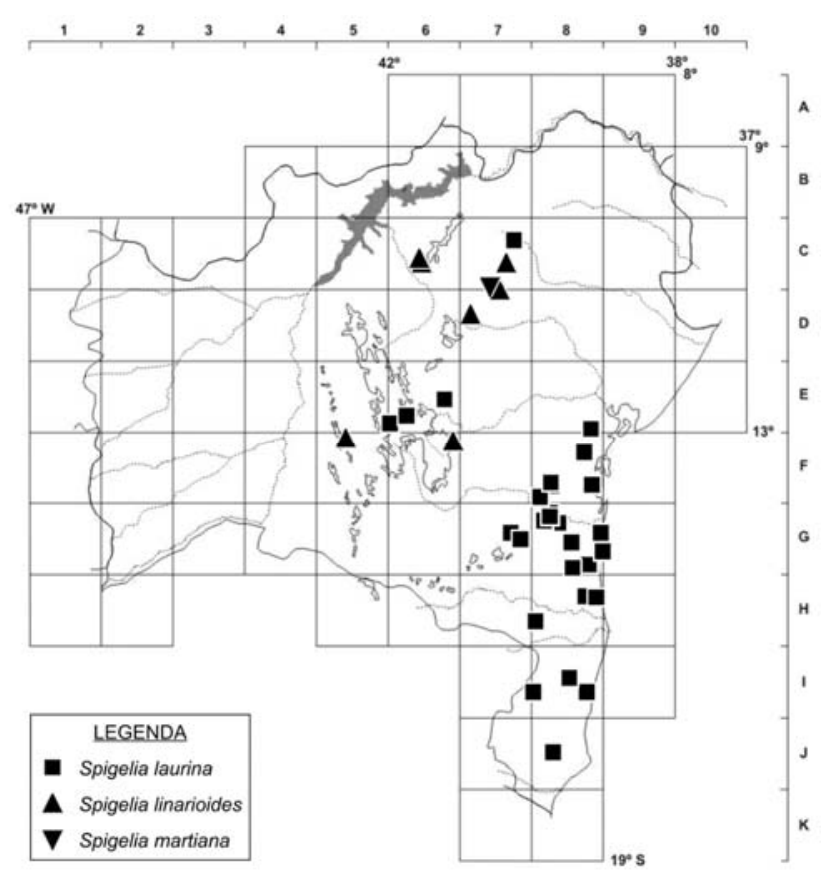

Figura 11. Mapa de distribuição de Spigelia laurina, S. linarioides e S. martiana no estado da Bahia.

obtusa na base, aguda a acuminada no ápice, revoluta a levemente revoluta nas margens, membranácea, glabra a glabrescente em ambas as faces, 1(2) par de nervuras secundárias; estípulas deltoides eventualmente truncadas no ápice. Cimeiras escorpioides, isoladas, terminais, 3-18 flores, 3-9 cm compr.; pedúnculo até $1,5 \mathrm{~cm}$ compr., glabro; brácteas $1-1,5 \times 0,1-0,2 \mathrm{~mm}$, filiformes, agudas a acuminadas no ápice, glabras nas margens. Flores sésseis ou pedicelo até $1 \mathrm{~mm}$ compr. Sépalas 2-2,8 × 0,3-0,4 mm, lanceoladas, agudas no ápice, glabras nas margens. Corola lilás a púrpura, infundibuliforme; tubo $8-12 \mathrm{~mm}$ compr., glabro externa e internamente; lobos 2,5-3 × 1,5-2 mm, ovados, glabros interna e externamente. Estames inclusos; filete $1-1,5 \mathrm{~mm}$ compr.; anteras $1,8-2 \mathrm{~mm}$ compr. Ovário 0,5-0,8 mm compr.; estilete $9,5-10 \mathrm{~mm}$ compr.; estigma filiforme. Cápsulas verdes, 2,2-2,5 × 3,5-3,8 $\mathrm{mm}$; mericarpos arredondados, glabros. Carpoatlas não visto. Sementes não vistas.

É endêmica do Brasil, ocorrendo na Bahia, Minas Gerais, São Paulo, Paraná, Rio Grande do Sul e Santa Catarina (Guimarães et al. 2017). C7: campos rupestres, em afloramentos rochosos ou solos arenosos. Floresce e frutifica em abril.

Material examinado - Mirangaba, $10^{\circ} 57^{\prime} 14^{\prime \prime} \mathrm{S}, 40^{\circ} 34^{\prime} 33^{\prime \prime} \mathrm{W}$, 23 abr. 1981 (fl., fr.), W.N. Fonseca 388 (RB).

Spigelia martiana é uma nova ocorrência para a Bahia, embora tenha sido coletada em 1981. Trata-se de uma erva com ramos cilíndricos a subtetrágonos pela presença de quatro lamelas, folhas lanceoladas, geralmente sésseis, e corola lilás a púrpura, além das sépalas serem maior ou igual ao tamanho das cápsulas. Spigelia martiana é semelhante a S. schlechtendaliana, espécie dos campos rupestres do Sudeste e CentroOeste, mas pode ser facilmente distinta desta pelas 
folhas opostas (vs. verticiladas) e as inflorescências sésseis ou com pedúnculo de até $1,5 \mathrm{~cm}$ compr. (vs. pedúnculo com mais de $3 \mathrm{~cm}$ compr.).

\subsection{Spigelia olfersiana Cham. \& Schltdl., Linnaea 1(2): 206. 1826.}

Figuras 12F, 13 e $31 \mathrm{~B}$.

Subarbusto ereto, até $50 \mathrm{~cm}$ alt.; ramos verde-oliva a castanhos, cilíndricos, estrelado-tomentosos. Folhas opostas, sésseis ou pecíolo até $1,5 \mathrm{~mm}$ compr.; lâmina verde, discolor, 1,5-4,7 ×0,8-2,1 cm, ovada a ovadoelíptica, arredondada a subcordada na base, aguda a arredondada no ápice, revoluta ou não nas margens, estrelado-tomentosa na face adaxial, densamente estrelado-tomentosa na abaxial, 3 ou 4 pares de nervuras secundárias; estípulas ovadas eventualmente truncadas no ápice, até $0,2 \mathrm{~mm}$ compr. Cimeiras escorpioides, isoladas, terminais, 4-27 flores, 2-11 cm compr.; pedúnculo 1,2-5 $\mathrm{cm}$ compr., estreladotomentoso; brácteas 1-2 $\mathrm{mm}$ compr., lanceoladas, agudas no ápice, estrelado-tomentosas nas margens. Flores com pedicelo ca. 0,5 mm compr. Sépalas 2-2,5 $\times$ 0,6-1 mm, lanceoladas, acuminadas no ápice, estreladotomentosas nas margens. Corola creme com lobos púrpura, infundibuliforme; tubo 8-9 $\mathrm{mm}$ compr., externamente estrelado-tomentoso, internamente glabro; lobos 2,5-3 × 2,4-2,5 mm, ovados a largo-ovados, estrelado-tomentosos externamente, glabros internamente. Estames inclusos; filetes 1,4-1,6 mm compr.; anteras ca. 1,5 mm compr. Ovário 0,8-1,2 mm compr.; estilete 8,5-10,5 mm compr.; estigma filiforme. Cápsulas verdes, 4-4,5 × 6-6,5 mm; mericarpos arredondados, estrelado-tomentosos. Carpoatlas elíptico, arredondado nas extremidades; forame elíptico a largooblongo. Sementes $8,1-1,5 \times 0,8-1 \mathrm{~mm}$.

É endêmica do Brasil, ocorrendo na Bahia e Minas Gerais (Guimarães et al. 2017). F6: campos rupestres, crescendo exposta ao sol, em afloramentos rochosos ou solos arenosos.

Material examinado - Rio de Contas, $13^{\circ} 34^{\prime} 00^{\prime \prime} \mathrm{S}$, 4149'47"W, s.d. (fl., fr.), C.F.P. Martius s.n. (M, foto).

Material adicional - BRASIL. MINAS GERAIS: Itabirito, 19 dez. 1970 (fr.), L. Krieger 9658 (HUEFS).

Spigelia olfersiana é uma nova ocorrência para Bahia. Pertence à seção Tomentosae, caracterizada principalmente por incluir subarbustos completamente recobertos por indumento estrelado-tometoso e anteras inclusas (exceto S. sellowiana). É morfologicamente semelhante a $S$. heliotropoides e $S$. sellowiana, diferindo pelos ramos com nós mais espaçados (entre nós mais longos), as sépalas menores (vs. maiores) que a metade do comprimento das cápsulas.

2.17. Spigelia polystachya Klotzsch ex Progel in Martius, Fl. Bras. 6(1): 265. 1868.

Figuras 12G-L, 13 e $31 \mathrm{C}$.

Erva ereta, ramificada, a subarbusto, 10-23 cm alt.; ramos verdes, cilíndricos, 4-costados, papilosos. Folhas opostas, sésseis; lâmina verde, discolor, 2-5,5 $\times \quad 0,2-0,9 \mathrm{~cm}$, lanceolada a oblongo-lanceolada, truncada a cuneada na base, cuneada a arredondada no ápice, membranácea a papirácea, glabra em ambas as faces, 2 ou 3 pares de nervuras secundárias; estípulas ovado-deltoides. Cimeiras escorpioides, isoladas, terminais e axilares, 4-30 flores, 2-8,5 cm compr.; pedúnculo 0,3-3 cm compr., papiloso; brácteas ca. 0,5 $\mathrm{mm}$ compr., ovadas, agudas no ápice, papilosas nas margens. Flores com pedicelos 0,1-0,3 mm compr. Sépalas $0,5-0,8 \times 0,3-0,5 \mathrm{~mm}$, ovadas, agudas no ápice, papilosas nas margens. Corola branca, campanulada a urceolada; tubo 0,9-1 $\mathrm{mm}$ compr., externamente papiloso, internamente velutino, moniliforme; lobos $0,4-0,6 \times 0,4-0,5 \mathrm{~mm}$, ovadodeltoides, externamente papilosos, internamente glabros. Estames inclusos; filetes 0,1-0,2 mm compr.; anteras 0,2-0,3 mm compr. Ovário ca. 0,3 mm compr.; estilete $0,3-0,5 \mathrm{~mm}$ compr.; estigma filiforme. Cápsulas verdes, 2-2,5 × 2,5-3 mm; mericarpos arredondados, papilosos. Carpoatlas largo-oblongo, arredondado nas extremidades; forame largo-oblongo. Sementes 14, 1-1,3 × 0,5-0,7 mm.

Endêmica do Brasil, ocorrendo na Bahia, Pernambuco, Piauí e Rio Grande do Norte (Guimarães et al. 2017). B6, C8, E4, E8, F4 e F6: caatingas e cerrados, principalmente em locais encharcados, próximo a lagos temporários, em solos areno-argilosos e hidromórficos em locais ensolarados. Floresce e frutifica em fevereiro, junho, julho, agosto e novembro.

Material selecionado - Andaraí, 12 ${ }^{\circ} 45^{\prime} 52^{\prime \prime} \mathrm{S}, 41^{\circ} 18^{\prime} 46^{\prime \prime} \mathrm{W}, 30$ ago. 2008 (fl.), E. Melo et al. 12155 (HUEFS); Bendengó, 09³4'59"S, 39॰11'18"W, 23 fev. 2000 (fl., fr.), A.M. Giulietti \& R.M. Harley 1765 (HUEFS); Cachoeira, 12³1'S, 3949'W, nov. 1980 (fl.), Grupo Pedra do Cavalo 915 (ALCB, HUEFS); Conceição da Feira, 12³0'21"S, 3859'56"W, jun. 1980 (fl., fr.), Grupo Pedra do Cavalo 233 (HUEFS); Feira de Santana, 12³1'S, 39³0'W, 31 jul. 1980 (fl.), L.R. Noblick 1940 (HUEFS); Morpará, $11^{\circ} 41^{\prime} \mathrm{S}, 43^{\circ} 00^{\prime} \mathrm{W}, 4$ jun. 2007 (fl., fr.), A.A. Conceição et al. 2266 (HUEFS); Riacho de Santana, $13^{\circ} 27^{\prime} 47^{\prime \prime S}, 43^{\circ} 13^{\prime} 30^{\prime \prime} \mathrm{W}, 12 \mathrm{fev}$. 2000 (fl., fr.), L.P. Queiroz et al. 5907 (CEPEC, HUEFS); Sobradinho, $09^{\circ} 23^{\prime} 26^{\prime \prime S}, 40^{\circ} 46^{\prime} 40^{\prime \prime} \mathrm{W}, 5$ jun. 2010 (fl.), M.L. Guedes et al. 17227 (ALCB).

Spigelia polystachya é uma erva ramificada de pequeno porte, caracterizando-se principalmente por ocorrer em áreas alagadas, incomum às espécies de Spigelia (exceto S. anthelmia), e apresentar cimas multifloras. É facilmente diferenciada no gênero por apresentar corola campanulada a urceolada (vs. infundibuliforme), com tubo internamente piloso (vs. glabro).

2.18. Spigelia pulchella Mart., Nov. Gen. Sp. P1. 2(2): 128.1827.

Figuras 13, 14A-G e 31D.

Nome popular: crista-de-galo

Erva ereta a subarbusto ramificado, 50-150 cm alt.; ramos verdes, cinlindricos a subtetrágonos, costados, glabros. Folhas opostas, sésseis; lâmina verde, concolor, ca. $2 \times 0,3 \mathrm{~cm}$, lanceolada a oblongo- 


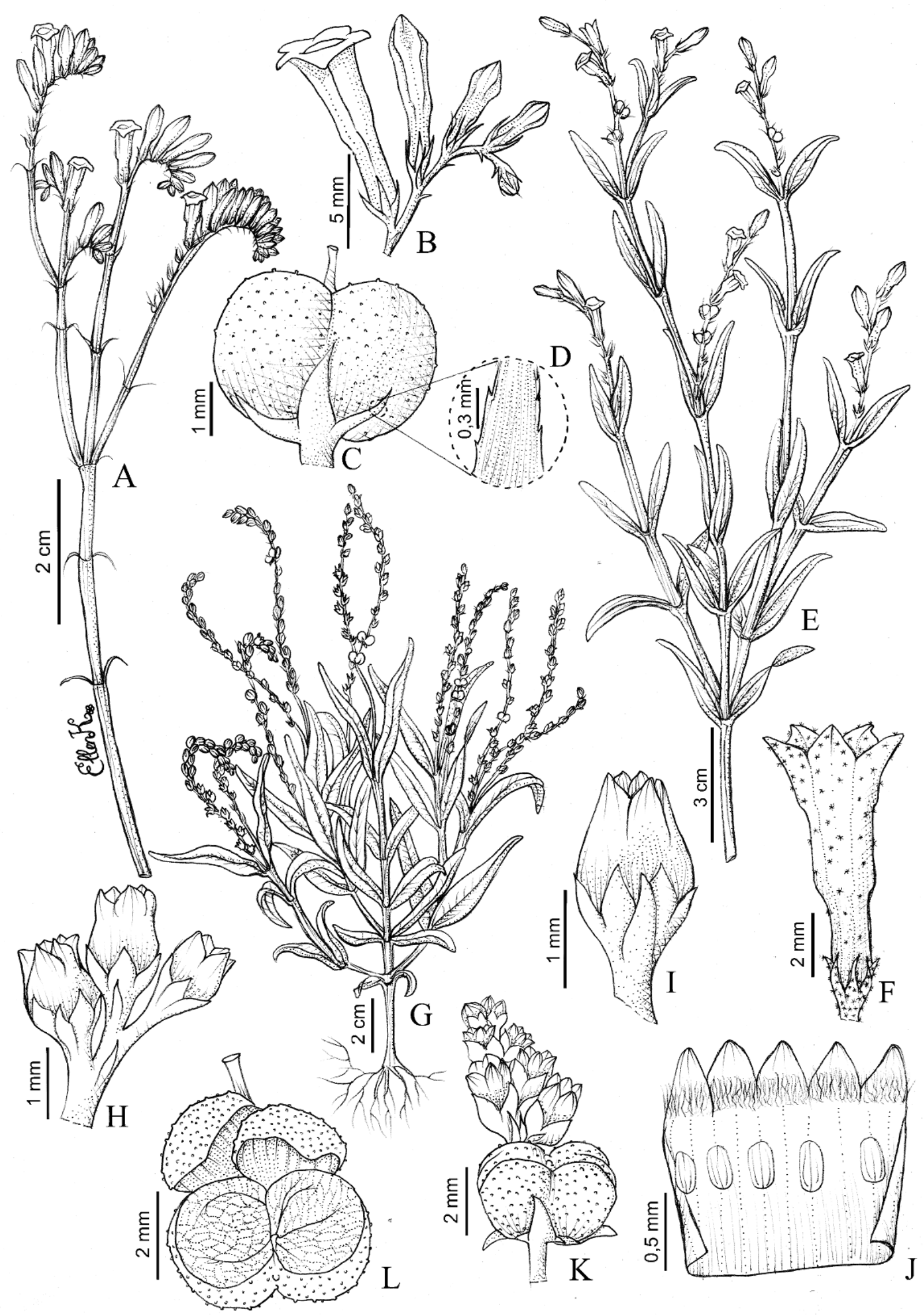

Figura 12. A-D. Spigelia linarioides: A- ramo fértil; B- parte da cimeira com flor e botões; C- cápsula papilosa; D- detalhe da sépala com margens denticuladas. E. S. martiana: ramo fértil. F. S. olfersiana: flor. G-L. S. polystachya: G- planta fértil; H- parte da cimeira com flores; I- flor; J- corola aberta; K- cimeira com cápsula e flores; L- cápsula, corte longitudinal, expondo sementes unidas pela placenta na porção axial. (A-D- Brandão 111; E- Fonseca 388; F- Krieger 13662; G-L- Grupo Pedra do Cavalo 915). 


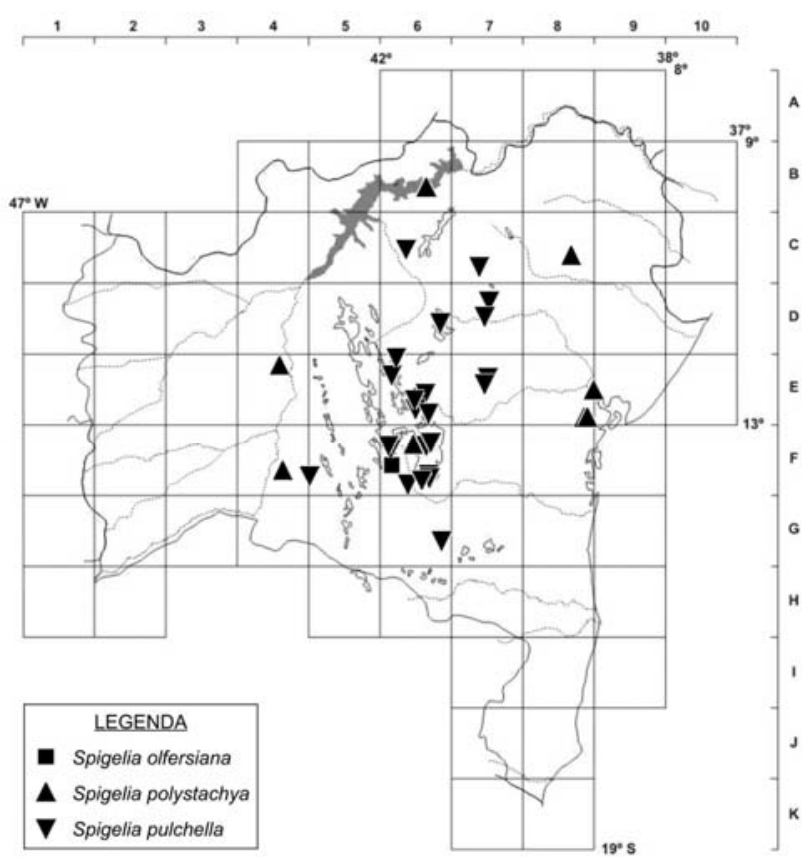

Figura 13. Mapa de distribuição de Spigelia olfersiana, S. polystachya e S. pulchella no estado da Bahia.

lanceolada, truncada na base, obtusa a arredondada no ápice, membranácea a papirácea, escabra na face adaxial, glabra na abaxial, hifódroma; estípulas lineares. Cimeiras escorpioides, isoladas, terminais, 6 30(50) flores, 4-15 cm compr.; pedúnculo 1,5-6 cm compr., glabro; brácteas ca. $2 \mathrm{~mm}$ compr., lanceoladas, acuminadas no ápice, glabras nas margens. Flores com pedicelos até $1 \mathrm{~mm}$ compr. Sépalas $2-3,5 \times 0,8-1 \mathrm{~mm}$, lanceoladas, agudas no ápice, glabras nas margens. Corola vermelha com lobos amarelos a purpúreos, infundibuliforme; tubo $30-35 \mathrm{~mm}$ compr., glabro externa e internamente; lobos 4-6 × 4-6 mm, deltoides, glabros. Estames exsertos; filetes 1-1,2 mm compr.; anteras 1,8-2 mm compr. Ovário 3,2-4,4 mm compr.; estilete 30-40 mm compr.; estigma capitado. Cápsulas verdes, 3,5-4 × 6-7 mm; mericarpos arredondados, glabros. Carpoatlas largo-elíptico, agudo nas extremidades; forame oblongo. Sementes 24, ca. $3,2 \times 3,2 \mathrm{~mm}$.

Endêmica da Bahia (Guimarães et al. 2017). C6, C7, D6, D7, E6, E7, F4/5, F6 e G6: campos rupestres e transição de cerrados para campos rupestres, em locais ensolarados, em bancos de areias ou entre pedras. Coletada com flores e frutos praticamente o ano todo.

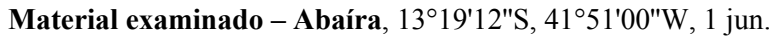
2003 (fl.), A.S. Conceição et al. 616 (HUEFS); Anagé, 14³7'32"S, 4107'57"W, 6 mar. 1993 (fl.), F.R. Salimena-Pires \& P.H. Nobre 360 (HUEFS); Andaraí, 1249'12"S, 41 ${ }^{\circ} 19^{\prime} 12^{\prime \prime} \mathrm{W}, 9$ out. 1987 (fl.), L.P. Queiroz et al. 1801 (HUEFS, MBM); Barra da Estiva,

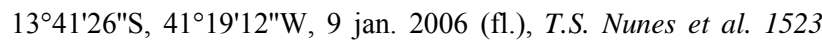
(HUEFS); Cascavel, 13ำ $16^{\prime} \mathrm{S}, 41^{\circ} 21^{\prime} \mathrm{W}, 24$ mar. 2005 (fl.), $R$. Funch \& L.S. Funch 763 (HUEFS); Catolés, 13¹7'07"S,

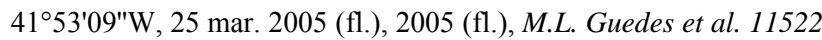
(ALCB); Contendas do Sincorá, $13^{\circ} 45^{\prime} 46^{\prime \prime} \mathrm{S}, 4^{\circ} 24^{\prime} 39^{\prime \prime} \mathrm{W}, 29$ out.
1978 (fl.), G. Martinelli 5472 (RB); Érico Cardoso, 13²4'39"S, 42 58'59"W, 4 jul. 2001 (fl.), T. Ribeiro 330 (ALCB, CEPEC, HUEFS); Ibicoara, $13^{\circ} 13^{\prime} 40^{\prime \prime S}, 41^{\circ} 16^{\prime} 54^{\prime \prime} \mathrm{W}, 18$ set. 2012 (fl.), K.M. Pimenta et al. 394 (HUEFS); Itaberaba, 12²4'27"S, 40³2'49"W, 16 jun. 2007 (fl.), D.O. Cerqueira et al. 9 (HUEFS); Itaeté, $12^{\circ} 36^{\prime} 10^{\prime \prime} \mathrm{S}, 41^{\circ} 23^{\prime} 33^{\prime \prime} \mathrm{W}, 21$ fev. 2004 (fl.), R. Funch 134 (HUEFS); Ituaçu, $13^{\circ} 43^{\prime} \mathrm{S}, 41^{\circ} 18^{\prime} \mathrm{W}, 18$ jul. 1981 (fl.), A.M. Giulietti et al. 1232 (HUEFS); Jacobina, $11^{\circ} 13^{\prime} 59^{\prime \prime} \mathrm{S}, 40^{\circ} 28^{\prime} 12^{\prime \prime} \mathrm{W}$, 14 out. 2007 (fl.), J.L. Ferreira \& F. França 151 (HUEFS); Lençóis, $12^{\circ} 32^{\prime} 31^{\prime \prime S}, 41^{\circ} 21^{\prime} 41^{\prime \prime W}, 12$ nov. 2016 (fl.), E.K.S. Brandão et al. 109 (HUEFS); Miguel Calmon, 11 $23^{\prime} 17^{\prime \prime S}$, 40³2'08"W, 4 abr. 2001 (fl.), H.P. Bautista et al. 3011 (ALCB, CEPEC, HUEFS); Morro do Chapéu, $11^{\circ} \mathrm{S}, 41^{\circ} \mathrm{W}, 5$ dez. 2002 (fl.), A. Rapini et al. 983 (HUEFS); Mucugê, $12^{\circ} 45^{\prime} \mathrm{S}, 41^{\circ} 30^{\prime} \mathrm{W}, 1$ nov. 2011 (fl.), I.M. Souza et al. 72 (HUEFS); Palmeiras, 12³7'54"S, 41³0'29"W, 4 mar. 2012 (f1.), G. Almeida-Silva \& F.G.

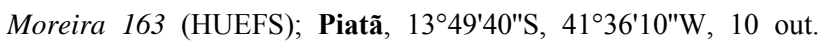
2009 (fl.), N. Roque 2275 (ALCB); Pindobaçu, 1044'30"S, 40³6'28"W, 10 mar. 1981 (fl.), R.P. Orlandi 336 (RB); Rio de Contas, $13^{\circ} 35^{\prime} 29^{\prime \prime S}, 41^{\circ} 47^{\prime} 58^{\prime \prime} \mathrm{W}, 30$ jan. 2005 (fl.), J. Paula-Souza et al. 5073 (HUEFS); Ruy Barbosa, 12 ${ }^{\circ} 18^{\prime} 24^{\prime \prime} \mathrm{S}, 40^{\circ} 29^{\prime} 20^{\prime \prime} \mathrm{W}, 28$ jul. 2004 (fl.), L.P. Queiroz et al. 9319 (HUEFS); Saúde, 1046'19"S, 4049'59"W, 14 jul. 2004 (fl., fr.), P. Fiaschi 2413

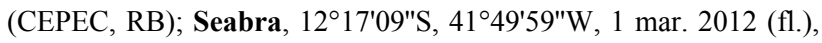
T.A. Pontes \& E.P. Lucas 296 (HUEFS); Senhor do Bonfim, 10²9'53"S, 41³8'20"W, 9 mar. 1997 (fl.), E. Nic Lughadha et al. 6158 (ALCB); Souto Soares, $12^{\circ} 02^{\prime} 01^{\prime \prime S}, 41^{\circ} 46^{\prime} 06^{\prime \prime} \mathrm{W}, 23 \mathrm{fev}$. 1971 (f1.), H.S. Irwin et al. 30799 (HUEFS).

Spigelia pulchella é uma erva subarbustiva, bastante frequente, que difere das demais espécies da seção Gracilis por apresentar porte maior, ramos costados aparentando tetrágonos, folhas diminutas e eretas ou ausentes, flores chamativas, com corola vermelha, alaranjada de ápice amarelo, ou purpúrea, de onde provém seu nome popular, crista-de-galo. Quando jovem e em botões pode ser confundida com $S$. tetraptera, S. gracilis ou $S$. linarioides, se diferenciando pelos ramos 4-costados e subtetrágonos (vs. tetrágono lamelados na primeira e cilíndrico, sulcado, nas duas últimas).

\subsection{Spigelia scabra Cham. \& Schltdl., Linnaea 1: 202. 1826.}

Figuras $14 \mathrm{H}-\mathrm{M}, 15$ e $31 \mathrm{E}$.

Erva ereta, por vezes ramificada, $10-50 \mathrm{~cm}$ alt.; ramos verdes, tetrágonos, glabros a esparso-escabros. Folhas verticiladas no ápice e opostas para a base dos ramos; pecíolo até $1 \mathrm{~cm}$ compr.; lâmina verde, discolor, $2-8 \times 0,8-2 \mathrm{~cm}$, elíptica a ovado-elíptica, atenuada na base, acuminada a aguda no ápice, inteira nas margens, papirácea, escabra na face adaxial, mais densamente nas margens, glabra na face abaxial, 4-6 pares de nervuras secundárias; estípulas ovadodeltoides a truncadas no ápice, ca. $2 \mathrm{~mm}$ compr. Cimeiras escorpioides, isoladas, terminais, 1-7 flores, 1,2-4 cm compr.; pedúnculo até $0,5 \mathrm{~cm}$ compr., glabro; brácteas ca. 0,5 $\mathrm{mm}$ compr., lanceoladas, agudas no ápice, denticuladas nas margens. Flores sésseis ou pedicelo até $0,1 \mathrm{~mm}$ compr. Sépalas $2,5-3 \times 0,5-0,8$ 


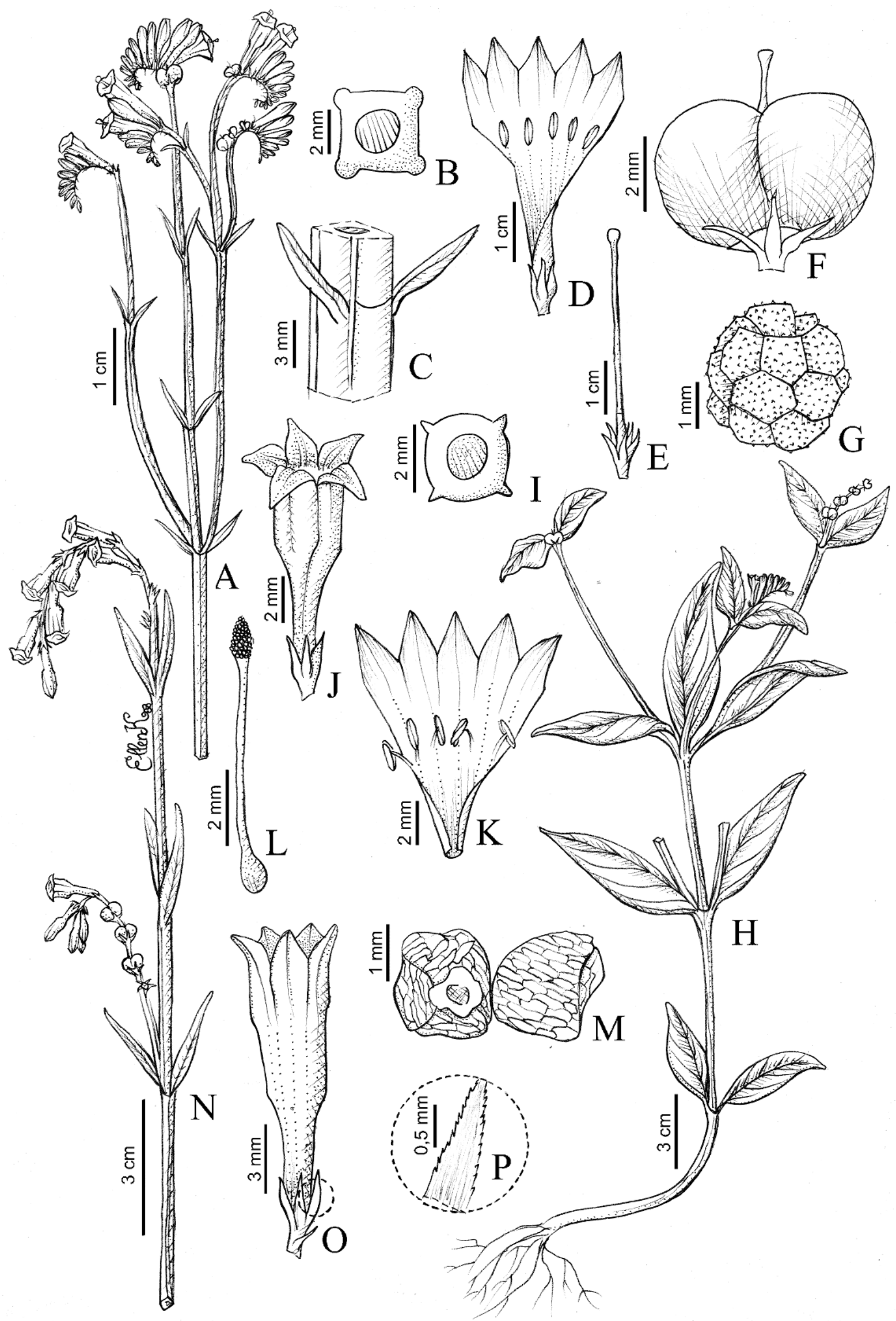

Figura14. A-G. Spigelia pulchella: A- ramo fértil; B- ramo, corte transversal; C- nó, com estípulas lineares; D- flor, com corola aberta; E- cálice e pistilo; F- cápsula; G- sementes aglomeradas ao redor da placenta. H-M. S. scabra: H- planta fértil; I- ramo, corte transversal; J- flor; K- corola aberta; L- pistilo; M- sementes, face ventral à esquerda e dorsal à direita. N-P. S. spartioides: N- ramo fértil; O- flor; P- detalhe da sépala. (A-G- Brandão 88; H-M- Queiroz 12081; N-P- Queiroz 5523). 
mm, lanceoladas, agudas no ápice, denticuladas nas margens. Corola branca, infundibuliforme; tubo 7,99,5 mm compr., glabro externa e internamente; lobos 1,5-2,5 × 1,5-2,5 mm, deltoides, glabros externa e internamente. Estames inclusos; filetes 1,5-2 $\mathrm{mm}$ compr.; anteras 1,2-1,5 mm compr. Ovário ca. 0,5 mm compr.; estilete 6-7 $\mathrm{mm}$ compr.; estigma filiforme. Cápsulas verdes, 4-4,5 × 5-5,5 mm; mericarpos angulosos, escabros. Carpoatlas elíptico, arredondado nas extremidades; forame elíptico. Sementes 12, 1,5-2 $\times 1-1,5 \mathrm{~mm}$.

Ocorre na Bolívia, Equador, Paraguai, Venezuela e Uruguai. No Brasil, é encontrada nos estados da Bahia, Espírito Santo, Goiás, Mato Grosso do Sul, Mato Grosso, Minas Gerais, Pará, Paraná, Pernambuco, Rio de Janeiro, Rio Grande do Sul, Santa Catarina e São Paulo (Guimarães et al. 2017). E7 e G8: florestas ombrófilas denso-montanas e submontanas, em solos humíferos, no interior de matas preservadas ou em áreas perturbadas com baixa incidência luminosa. Floresce e frutifica de janeiro a março.

Material examinado - Ilhéus, $14^{\circ} 48^{\prime} 00^{\prime \prime} \mathrm{S}, 39^{\circ} 40^{\prime} 12^{\prime \prime} \mathrm{W}, 27$ mar. 1996 (fl.), L.A.M. Silva 3418 (CEPEC); Itaberaba, 12²4'55"S, 40²3'39"W, 18 jan. 2006 (fl.), L.P. Queiroz et al. 12081 (HUEFS).

Spigelia scabra é uma erva típica de mata úmida, com ramos subtetrágonos a tetrágonos, folhas escabras, com tricomas concentrados nas bordas, inflorescências sésseis, com poucas flores, corola alva, geralmente quatro vezes mais longa que as sépalas, as quais ultrapassam a metade da cápsula. É similar a $S$. brachystachya (ver comentários daquela espécie) e $S$. laurina, diferindo desta última pelos ramos subtetrágonos a tetrágonos (vs. cilíndricos), corola mais curta (9,5-12 vs. $15-20 \mathrm{~mm}$ compr.) e frutos com mericarpos escabros (vs. glabros).

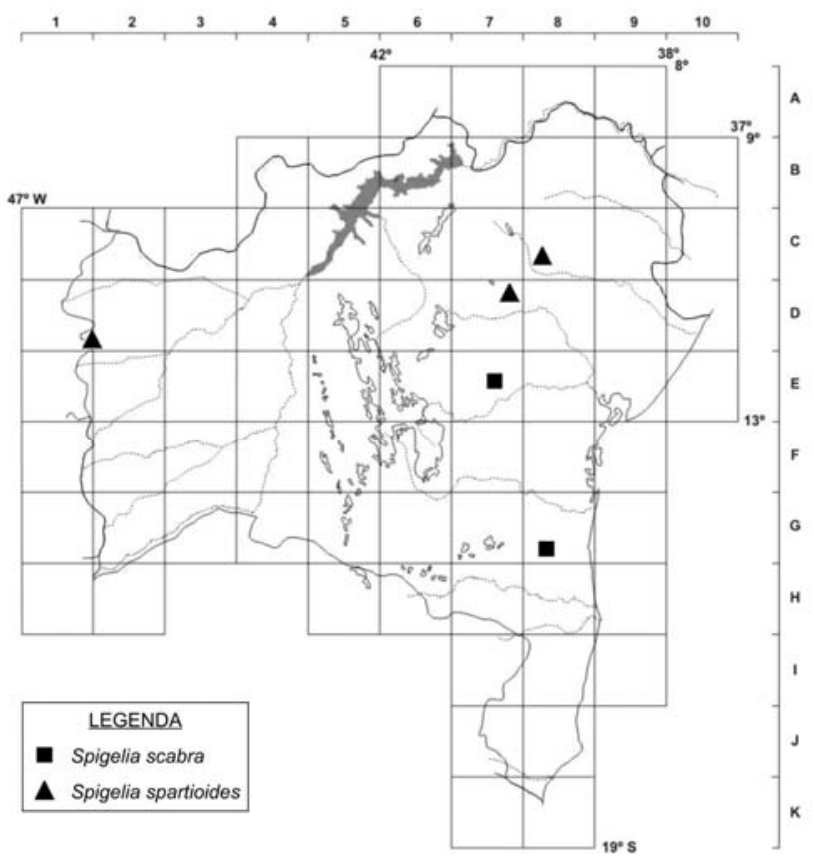

Figura 15. Mapa de distribuição de Spigelia scabra e S. spartioides no estado da Bahia.
2.20. Spigelia spartioides Cham., Linnaea 8: 14. 1833.

Figuras $14 \mathrm{~N}-\mathrm{P}, 15$ e $31 \mathrm{~F}$.

Erva ereta, cespitosa, 40-50 cm alt.; ramos verdes, cilíndricos a tetrágonos, 4-costados, papilosos nas costelas e próximo aos nós; estípulas truncadas. Folhas opostas, sésseis; lâmina verde, discolor, 1-3× 1,5-2 cm, linear a ovado-lanceolada, truncada na base, arredondada a acuminada no ápice, revoluta nas margens, cartácea, escabra na face adaxial, com tricomas concentrados no ápice, escabra na face abaxial, hifódroma. Cimeiras escorpioides, isoladas, terminais, 10-16 flores, 6-8 cm compr.; pedúnculo 1,5-4 cm compr., glabro; brácteas 1,5-3,5 mm compr., lanceoladas, acuminadas no ápice, denticuladas nas margens. Flores sésseis. Sépalas 4-5 $\times 0,8-1 \mathrm{~mm}$, lanceoladas, denticuladas nas margens. Corola rosa a alva com guias de néctar rosa; tubo 11$12 \mathrm{~mm}$ compr., glabro externa e internamente; lobos $1-1,5 \times$ ca. $2 \mathrm{~mm}$, deltoides, glabros. Estames inclusos; filetes 1,5-2 $\mathrm{mm}$ compr.; anteras 1,2-1,5 mm compr. Ovário ca. 0,5 mm compr.; estilete 10-12 mm compr.; estigma filiforme. Cápsulas 3-3,5 × 4-4,5 $\mathrm{mm}$; mericarpos arredondados, papilosos. Carpoatlas elíptico, arredondado a cuneado nas extremidades; forame circular a largo-elíptico. Sementes $16,0,8-1 \times$ 0,5-0,8 mm.

Endêmica do Brasil, ocorrendo na Bahia e em Minas Gerais (Guimarães et al. 2017). C8, D1/2 e D7: campos rupestres, crescendo exposta ao sol, em afloramentos rochosos. Floresce e frutifica de janeiro a março.

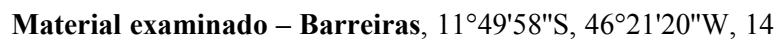
jan. 2007 (fl., fr), J.F.B. Pastore et al. 2400 (HUEFS); Bela Vista, $10^{\circ} 39^{\prime} \mathrm{S}, 39^{\circ} 43^{\prime} \mathrm{W}, 30$ mar. 2004 (fl., fr), M.V. Moraes 673

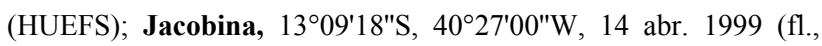
fr.), L.P. Queiroz et al. 5523 (HUEFS).

Spigelia spartioides é mais uma das espécies que compõe a seção Gracilis (veja comentários em $S$. gracilis, S. linarioides e S. pulchella). É caracterizada por apresentar ramos tetrágonos, com costas lameladas, folhas opostas, lanceoladas, truncadas na base, acuminadas a arredondadas no ápice, com tricomas esparsos formando indumento escabro no ápice, sépalas denticulado-serreadas, não ultrapassando a metade da cápsula, e corola purpúrea a rosa.

\section{Strychnos L.}

Lianas, trepadeiras a arbustos escandentes, raramente subarbusto, ervas ou árvores; ramos lenticelados ou não; gavinhas e/ou espinhos geralmente presentes. Folhas opostas, venação subacródroma; estípulas lineares. Tirsos corimbiformes ou tirsiformes, terminais e/ou axilares, pauci ou multifloros; brácteas 1 par por flor, lanceoladas, ovadas, ovado-lanceoladas ou deltoides. Flores (4)5(6)-meras. Cálice dialissépalo, persistente; sépalas iguais entre si. Corola hipocrateriforme a curto-infundibuliforme. Estames 
inclusos a semiexsertos, anteras dorsifixas a basifixas, glabras ou pilosas. Ovário pluriovulado; estilete incluso ou exserto, não articulado; estigma capitado (indiviso), raro cônico, papiloso. Bagas globosas a subglobosas. Carpoatlas ausente. Sementes 1, 2 ou numerosas, acinzentadas, negrejantes a castanhas, discoides a esféricas, ovadas, oblongas a largoelípticas; testa lisa ou levemente rugosa.

Strychnos é um gênero pantropical com cerca de 200 espécies, distribuídas na Ásia, África, e nas Américas (Krukoff \& Monachino 1942; Krukoff \& Barneby 1969). O Brasil, principal centro de diversidade do gênero, abriga 68 das 71 espécies citadas para as Américas. $O$ gênero tem ampla distribuição, encontrado geralmente no interior de florestas úmidas da Mata Atlântica e da Amazônia. Na Bahia, foram encontradas 21 espécies, sendo $S$. alvimiana e S. setosa endêmicas do estado (Progel
1868; Krukoff \& Monachino 1942; Ducke 1965; Krukoff \& Barneby 1969; Guimarães et al. 2017). Progel (1868) reconheceu três secções em Strychnos: Longiflorae Progel, Rouhamon (Aubl.) Progel e Breviflorae Progel, com base principalmente em caráteres reprodutivos como forma e indumento da corola e estames, bem como a relação entre $o$ comprimento do estigma e do ovário; delimitação esta aceita por Krukoff \& Monachino (1942) na revisão taxonômica do gênero. As espécies da Bahia se distribuem em duas secções: Longiflorae, de corola hipocrateriforme e anteras glabras, e Breviflorae, de corola curto-infundibuliforme e anteras pilosas. Morfologicamente, Breviflorae é a seção mais complexa, por apresentar difícil delimitação entre as espécies; as demais secções apresentam padrões diagnósticos bastante distintos e de fácil classificação.

\section{Chave para as espécies}

1. Folhas amareladas, castanho-amareladas ou verde-amareladas quando secas; corola hipocrateriforme (exceto $S$. solimoesana); anteras glabras; ovário com comprimento menor que o estilete.

2. Folhas glabras na face adaxial, velutinas na abaxial.

3. Árvore; ramos estriados, vilosos quando jovens, glabrescentes; folhas quintuplinérveas

3. Trepadeira; ramos lisos ou levemente ru................................................................. 3.15. S. pseudoquina

2'. Folhas glabras, pubescentes, pilosas ou pubérulas em uma ou ambas as faces, mas não velutinas abaxialmente.

4. Corola com tubo pubérulo, pubescente ou densamente estrigoso externamente.

5. Corola com tubo estrigoso externamente; sépalas lanceoladas, 2,5-3 mm compr. .... 3.21. S. trinervis

5'. Corola com tubo pubérulo ou pubescente externamente; sépalas ovadas ou largamente ovadas, 0,5-2 mm compr.

6. Face abaxial da lâmina foliar glabra a glabrescente, sem tufos de tricomas na axila do par de nervuras internas; corola com tubo externamente pubescente; sépalas largamente ovadas, $0,5-0,8$ mm compr.; estilete 10-12 mm compr. .

3.14. S. peckii

6'. Face abaxial da lâmina foliar glabra com tufos de tricomas apenas na axila do par de nervuras internas; corola com tubo externamente pubérulo; sépalas ovadas, 1,5-2 mm compr.; estilete 5,5$6 \mathrm{~mm}$ compr.

3.8. S. gardneri

4'. Corola com tubo papiloso externamente.

7. Tirsos apenas terminais; brácteas lanceoladas; tubo da corola maior que $10 \mathrm{~mm}$ compr.

8. Sépalas 1-1,2 mm compr., ovado-deltoides; corola 17-18(-20) mm compr. ... 3.6. S. divaricans

8'. Sépalas 1,2-1,5 mm compr., lanceoladas; corola 12-15 mm compr.

3.4. S. bahiensis

7'. Tirsos axilares e terminais; brácteas ovadas; tubo da corola menor ou igual a $8 \mathrm{~mm}$ compr.

9. Corola 6,5-7,5 $\mathrm{mm}$ compr.; pistilo menor que $9 \mathrm{~mm}$ compr. 3.17. S. romeubelenii

9'. Corola ca. $10 \mathrm{~mm}$ compr.; pistilo maior ou igual a $10 \mathrm{~mm}$ compr.

10. Tirsos com até 12 flores; sépalas $0,8-1 \mathrm{~mm}$ compr.; corola com tubo piloso internamente; estilete 9-11 mm compr.; bagas com pericarpo fibroso, maiores ou iguais a 4,5 cm compr. ...

3.7. S. erichsonii

10'. Tirsos com 15 ou mais flores; sépalas 1-2 mm compr.; corola com tubo densamente piloso internamente; estilete 8-8,5 mm compr.; bagas com pericarpo subcoriáceo, menores que 4,5 cm compr.

3.10. S. mitscherlichii

1'. Folhas verdes, verde-acinzentadas, verde-oliva, castanhas a negrejantes quando secas; corola curtoinfundibuliforme; anteras pilosas; ovário com comprimento igual ou maior que o estilete.

11. Erva a subarbusto, até $0,4 \mathrm{~m}$ alt.; lâmina foliar até $1 \mathrm{~cm}$ compr. 3.11. S. nana

11'. Liana, trepadeira ou arbusto, mais que $1 \mathrm{~m}$ alt.; lâmina foliar mais que $2 \mathrm{~cm}$ compr.

12. Tirsos com pedúnculo 3-4,5 cm compr. e muitas brácteas; brácteas $7-12 \mathrm{~mm}$ compr., geralmente negrejantes quando secas

3.2. S. alvimiana

12'. Tirsos com pedúnculo até $3 \mathrm{~cm}$ compr. e poucas brácteas; brácteas até $7 \mathrm{~mm}$ compr., verdes.

13. Lâmina foliar densamente velutina em ambas as faces, ferrugínea 3.18. S. rubiginosa 
13'. Lâmina foliar glabra, pubescente, pubérula, pilosa, hirtela ou tomentosa, não ferrugínea.

14. Ramos sem espinhos e gavinhas; flores com pedicelo maior que $0,4 \mathrm{~mm}$ compr., sépalas com mais de $2 \mathrm{~mm}$ compr.

3.19. S. setosa

14'. Ramos com espinhos e gavinhas; flores subsésseis ou com pedicelo até $0,2 \mathrm{~mm}$ compr., sépalas com menos de $2 \mathrm{~mm}$ compr.

15. Corola menor que $2,4 \mathrm{~mm}$ compr.; bagas com pericarpo fibroso

3.9. S. mattogrossensis

15'. Corola maior ou igual a 2,4 mm compr.; bagas com pericarpo suculento ou coriáceo.

16. Inflorescências laxas, raro congestas; pedicelo $1,8-5 \mathrm{~mm}$ compr.

17. Ramos densamente lenticelados, glabros, escabriúsculos a hirsutos, gavinhas lenhosas; folhas com nervuras conspícuas; flores com pedicelo 1,8-2 mm compr.; bagas com pericarpo subcoriáceo ..... 3.5. S. brasiliensis

17'. Ramos pouco lenticelados, pilosos, pubescentes a glabrescentes, gavinhas herbáceas; folhas com nervuras inconspícuas; flores com pedicelo 2-3 mm compr.; bagas com pericarpo suculento 3.12. S. nigricans

16'. Inflorescências sempre congestas; pedicelo até $1,5 \mathrm{~mm}$ compr.

18. Arvoreta ou arbusto escandente; folhas com margens ciliadas; bagas com pericarpo suculento 3.13. S. parvifolia

18'. Trepadeira ou liana; folhas com margens glabras; bagas com pericarpo coriáceo a subcoriáceo.

19. Lâmina foliar hirtela a tomentosa na face abaxial; tirsos com pedúnculo maior que $2 \mathrm{~cm}$ compr.

3.16. S. recognita

19'. Lâmina foliar glabra a esparso-pubescente na face abaxial; tirsos sésseis ou pedúnculo menor que $1,5 \mathrm{~cm}$ compr.

20. Brácteas 1-1,5 mm compr., ovadas a largamente ovadas; tirsos com até 12(-15) flores; sépalas até $1 \mathrm{~mm}$ compr., largamente ovadas; corola $3 \mathrm{~mm}$ compr. ou mais ... 3.1. S. acuta

20'. Brácteas 3-4 mm compr., lanceoladas; tirsos com 15 flores ou mais; sépalas 1,2 $\mathrm{mm}$ compr. ou mais, lanceoladas; corola menos que $2 \mathrm{~mm}$ compr. 3.3. S. atlantica

3.1. Strychnos acuta Progel in Martius, Fl. Bras. 6(1): 280.1868.

Figuras $16 \mathrm{~A}-\mathrm{D}, 17$ e $31 \mathrm{G}$.

Arbusto a trepadeira, 2-5 m alt.; ramos castanhoacinzentados, cilíndricos, glabros a pubescente; lenticelas puntiformes; gavinhas presentes. Folhas sésseis ou pecíolo até $2 \mathrm{~mm}$ compr.; lâmina verde, mesmo quando seca, discolor, 2-8,5 × 1-3,5 cm, elíptica, ovada, ovado-elíptica a ovada-lanceolada, cuneada a arredondada na base, aguda no ápice, raramente revoluta nas margens, subcoriácea a cartácea, glabra a esparso-pubescente em ambas as faces, triplinérvea ou raro quintuplinérvea. Tirsos terminais, congestos, 9-12(-15) flores; pedúnculo até $0,4 \mathrm{~cm}$ compr., glabro ou esparso-pubérulo a pubescente; brácteas 1-1,5 mm compr., ovadas a largo-ovadas, agudas no ápice, ciliadas nas margens. Flores sésseis ou pedielo até $1 \mathrm{~mm}$ compr. Sépalas $0,8-1 \times 0,3-0,5 \mathrm{~mm}$, largo-ovadas, cuneadas no ápice, ciliadas nas margens. Corola amarela a amarelo-esverdeada, curto-infundibuliforme; tubo 1$1,5 \mathrm{~mm}$ compr., glabro a minutamente papiloso externamente, glabro internamente; lobos 2-2,2 $\times$ 0,8-1 mm, ovados, minutamente papilosos externamente, barbados internamente. Estames semiexsertos; filetes $0,1-0,2 \mathrm{~mm}$ compr.; anteras $0,75-0,8 \mathrm{~mm}$ compr., basifixas, pilosas na base. Ovário $0,5-0,7 \mathrm{~mm}$ compr.; estilete $1-1,2 \mathrm{~mm}$ compr.; estigma capitado. Bagas amarelas, 3-3,5 $\times$ 2,8-3,2; pericarpo coriáceo, liso. Sementes 2, negrejantes, 1,5-1,8 × 1,3-1,6.

Endêmica do Brasil, ocorrendo na Bahia, Espírito Santo, Minas Gerais, Rio de Janeiro e São Paulo (Krukoff \& Monachino 1942; Guimarães et al. 2017). I8 e K8: florestas ombrófilas densas, montanas e submontanas, em áreas preservadas, na borda ou interior de matas. Encontrada com frutos em maio.

Material examinado - Belmonte, $16^{\circ} 08^{\prime} \mathrm{S}, 39^{\circ} 15^{\prime} \mathrm{W}, 13$ maio 1993 (fr.) W.W. Thomas et al. 9918 (CEPEC); Mucuri, $18^{\circ} 05^{\prime} 50^{\prime \prime} \mathrm{S}, 39^{\circ} 33^{\prime} 28^{\prime \prime} \mathrm{W}, 16$ jul. 1968 (est.), R.P. Belém 3880 (CEPEC).

Material adicional - BRASIL. ESPÍRITO SANTO: Linhares, Parque do Rio Doce, 27 mar. 1971 (fl.), T.S. Santos 1489 (CEPEC). PARAÍBA: Bananeiras, Brejo Paraibano, APA do Roncador, $07^{\circ} 18^{\prime} \mathrm{S}, 35^{\circ} 55^{\prime} \mathrm{W}, 11$ dez. 2011 (fl.), E. Melo et al. 10812 (HUEFS). RIO DE JANEIRO: s.d. (fr.), C. Glaudino 776 (isótipo de S. acuta: P [foto]); Parque Municipal Ecológico da Prainha, 13 nov. 2003 (fl.), J.M.A. Braga 7255 (RB).

Strychnos acuta pertence à seção Breviflorae, que se caracteriza pela inflorescência exclusivamente terminal, corola curto-infundibuliforme, tubo menor ou igual ao tamanho dos lobos do cálice, lobos da corola barbados, anteras usualmente pilosas na base, estilete menor ou igual ao tamanho do ovário e frutos com poucas sementes 1 ou 2(-4). Strychnos acuta pode ser um arbusto ou uma liana pouco lenhosa, com 
ramos completamente glabros ou mais raramente esparso-pubescentes na face abaxial das folhas, próximo às nervuras. Apresenta gavinhas herbáceas ou sublenhosas nos ramos mais jovens, lâmina foliar geralmente menor que $15 \mathrm{~cm}$ compr., com nervuras levemente reticuladas, geralmente proeminentes apenas na face abaxial. Caracteriza-se, ainda, por apresentar inflorescências terminais com poucas flores. Assemelha-se a $S$. atlantica, pelo hábito e forma das folhas. No entanto, S. acuta apresenta folhas com nervuras terciárias pouco proeminentes a planas (vs. proeminentes) na face abaxial, brácteas ovadas a largoovadas (vs. lanceoladas) e sépalas largo-ovadas e ciliadas nas margens (vs. lanceoladas e esparsociliadas).

\subsection{Strychnos alvimiana Krukoff \& Barneby,} Phytologia 27(2): 105. 1973.

Figuras $16 \mathrm{E}-\mathrm{G}, 17$ e $31 \mathrm{H}$.

Liana; ramos castanhos, cilíndricos a tetrágonos, glabros, rugosos; lenticelas pontiformes; espinhos e gavinhas presentes. Folhas com pecíolo $1-1,5 \mathrm{~cm}$ compr.; lâmina castanha a verde-parda quando seca, discolor, (3,5-)4-9,2 × (1,5-)2,7-4,3 cm, elíptica a largo-elíptica, redonda a cuneada na base, aguda a acuminada no ápice, revoluta nas margens, subcoriácea, glabra em ambas as faces, triplinérvea. Tirsos terminais, congestos, 50 ou mais flores; pedúnculo 3-4,5 cm compr., glabro; brácteas 7-12 mm compr., lanceoladas, agudas a acuminadas no ápice, denticuladas nas margens. Flores sésseis. Sépalas 4-5 $\times$ 1-1,2 mm, lanceoladas, agudas a acuminadas no ápice, esparso-denticuladas nas margens. Corola não vista. Bagas verde-escuras a amarelas quando passadas, 2,4-3,5 × 2,2-3 cm; pericarpo sublenhoso, levemente rugoso. Sementes 1 ou $2,1-1,8 \times 0,8-1,4$ $\mathrm{mm}$.

Endêmica da Bahia (Krukoff \& Barneby 1973; Guimarães et al. 2017). G8/9 e H8: florestas ombrófilas denso-montanas, submontanas ou matas de cipó, no interior de matas preservadas, matas costeiras ou ciliares. Encontrada com flores e frutos em julho e flores passadas em janeiro.

Material selecionado - Itacaré, $14^{\circ} 16^{\prime} 39^{\prime \prime} \mathrm{S}, 38^{\circ} 59^{\prime} 48^{\prime \prime} \mathrm{W}, 20$ jul. 1973 (fl., fr.), T.S. Santos et al. 2683 (CEPEC); Una, $15^{\circ} 17^{\prime} 35^{\prime \prime S}, 39^{\circ} 45^{\prime} 10^{\prime \prime} \mathrm{W}, 10$ jul. 1968 (fl.), R.P. Belém 3708 (CEPEC).

Segundo Krukoff \& Barneby (1973), Strychnos alvimiana está relacionada a $S$. nigricans e $S$. mattogrossensis por apresentarem frutos de pericarpo rígido e fibroso. É caracterizada principalmente por apresentar os ramos mais antigos tetrágonos, com espinhos aos pares, lenhosos, alongados ou diminutos, folhas pardas, com nervuras imersas na face abaxial e margens revolutas. Essas espécies diferem das demais espécies de Strychnos que ocorrem na Bahia por apresentarem inflorescências enegrecidas quando secas, densamente bracteadas e sépalas maiores (mais que 3,5 mm vs. menos que $3 \mathrm{~mm}$ compr.). Strychnos alvimiana diferencia-se de $S$. nigricans e $S$. mattogrossensis por apresentar hábito lianescente (vs. arbusto escandente) e folhas coriácea (vs. cartácea). Quando estéril assemelha-se a S. erichsonii (veja comentário naquela espécie). Como sugerido pelo autor da espécie, são necessárias coletas adicionais, pois a espécie é conhecida apenas a partir de flores passadas. Os frutos, com poucas sementes, examinados pela primeira vez para este estudo, confirmam sua classificação na seção Breviflorae.

\subsection{Strychnos atlantica Krukoff \& Barneby, Mem.} New York Bot. Gard. 20(1): 61. 1969.

Figuras 16H-L, 17 e 31I, J.

Trepadeira a liana 2-10 $\mathrm{m}$ alt.; ramos acinzentados, cilíndricos, glabros, pubérulos, pilosos ou híspidos; lenticelas ausentes; espinhos e gavinhas presentes. Folhas subsésseis ou pecíolo até $7 \mathrm{~mm}$ compr.; lâmina verde-oliva a castanho-escura quando seca, discolor, 4-16,8 × 2,7-6,2 cm, elíptica, ovadoelíptica a ovado-oblonga, cuneada a arredondada na base, aguda a acuminada no ápice, subcoriácea a cartácea, glabra em ambas as faces, triplinérvea ou quintuplinérvea. Tirsos terminais, congestos, 15-24 flores; pedúnculo até $7 \mathrm{~mm}$ compr., glabro a esparsopubescente; brácteas 3-4 $\mathrm{mm}$ compr., lanceoladas, agudas a acuminadas no ápice, ciliadas nas margens. Flores sésseis ou pedicelo ca. $1 \mathrm{~mm}$ compr. Sépalas 1,2-1,8 × 0,6-0,8 mm, lanceoladas, agudas no ápice, pilosas nas margens. Corola amarela, curtoinfundibuliforme; tubo 0,4-0,5 $\mathrm{mm}$ compr.; papiloso externamente, glabro internamente; lobos 1,2-1,3 $\times$ 0,5-0,8 mm, ovados, papilosos externamente, barbados para o ápice internamente. Estames semiexsertos; filetes $0,2-0,3 \mathrm{~mm}$ compr.; anteras $0,4-0,5 \mathrm{~mm}$ compr., basifixas, pilosas na base. Ovário 0,3-0,4 mm compr.; estilete 0,6-0,8 mm compr.; estigma capitado. Bagas amarelas, 3,1-5 × 3,3-5 cm; pericarpo coriáceo, rugoso. Sementes 4, 1,2-1,5 × 1,2-1,5 cm.

Endêmica do Brasil, ocorrendo na Bahia, Paraíba, Pernambuco e Espírito Santo (Krukoff \& Barneby 1969; Guimarães et al. 2017). G8, H8, H8/9 e I8: florestas ombrófilas denso-montanas e submontanas ou matas de cipó, em áreas preservadas, bordas de mata, matas ciliares ou em áreas de plantação de cacau. Encontrada com frutos em janeiro, março e junho.

Material selecionado - Arataca, $15^{\circ} 12^{\prime} 10^{\prime \prime} \mathrm{S}, 39^{\circ} 24^{\prime} 29^{\prime \prime} \mathrm{W}$, 13 set. 2009 (est.), A.M. Amorim et al. 7920 (CEPEC); Belmonte, 1551'47"S, 3852'58"W, 21 jan. 1967 (est.), R.P. Belém 3228 (CEPEC, RB); Camacan, $15^{\circ} 23^{\prime} 44^{\prime \prime S}$, 39 33'57"W, 18 maio 2010 (est.), D. Rocha 1118 (CEPEC); Ilhéus, 14²4'20"S, 39²9'38"W, 18 fev. 1992 (est.), S.C. Sant'Ana \& T.S. Santos 208 (CEPEC); Jussari, $15^{\circ} 11^{\prime} 29^{\prime \prime} \mathrm{S}, 39^{\circ} 29^{\prime} 43^{\prime \prime} \mathrm{W}, 15$ jun. 1968 (fr.), R.P. Belém 3712 (CEPEC); Porto Seguro, 16²6'58"S, 39³8'49"W, 25 mar. 1968 (fr.), S.G. Vinha \& T.S. Santos 133 (CEPEC); Santa Cruz de Cabrália, 16²16'41"S, 39 14'49"W, 22 maio 1975 (est.), T.S. Santos 3012 (CEPEC, RB); Uruçuca, 14²5'24"S, 3903'38"W, 28 mar. 1995 (est.), W.W. Thomas et al. 10887 (CEPEC). 


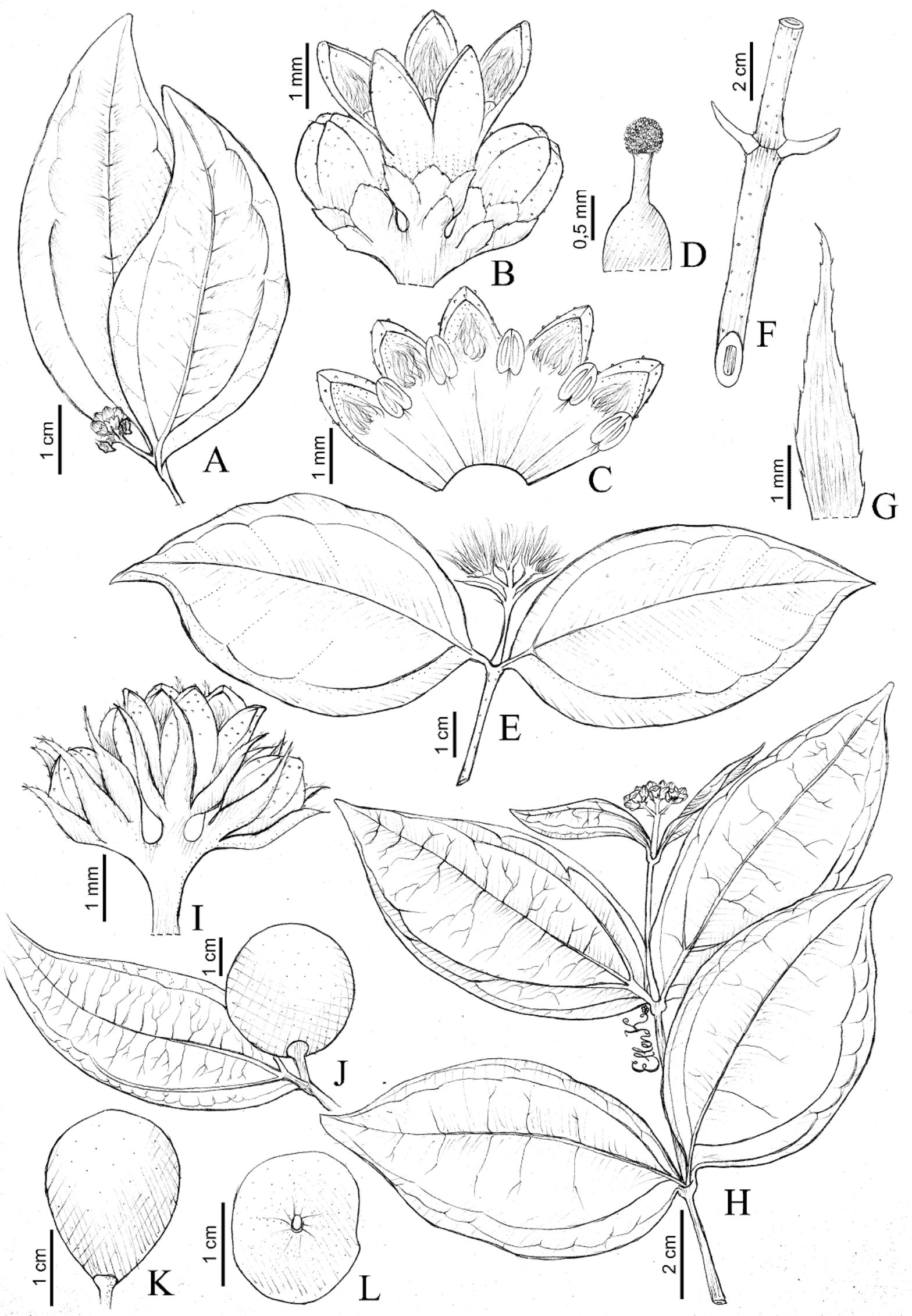

Figura 16. A-D. Strychnos acuta: A- ramo fértil; B- dicásio, com flor e botões; C- corola aberta; D- pistilo. E-G. S. alvimiana: E- ápice do ramo com tirso completamente bracteado; F- parte do ramo com espinhos lenhosos; G- sépalas com margens denticuladas. H-L. S. atlantica: H- parte apical do ramo fértil; I- dicásio, com flor e botões; J- ápice do ramo com baga; K- baga; L- semente, vista ventral. (A-D- Santos 1489; E-G- Santos 2683; H-I- Pinheiro 2281; J- Belém 3712; K-L- Belém 2278). 


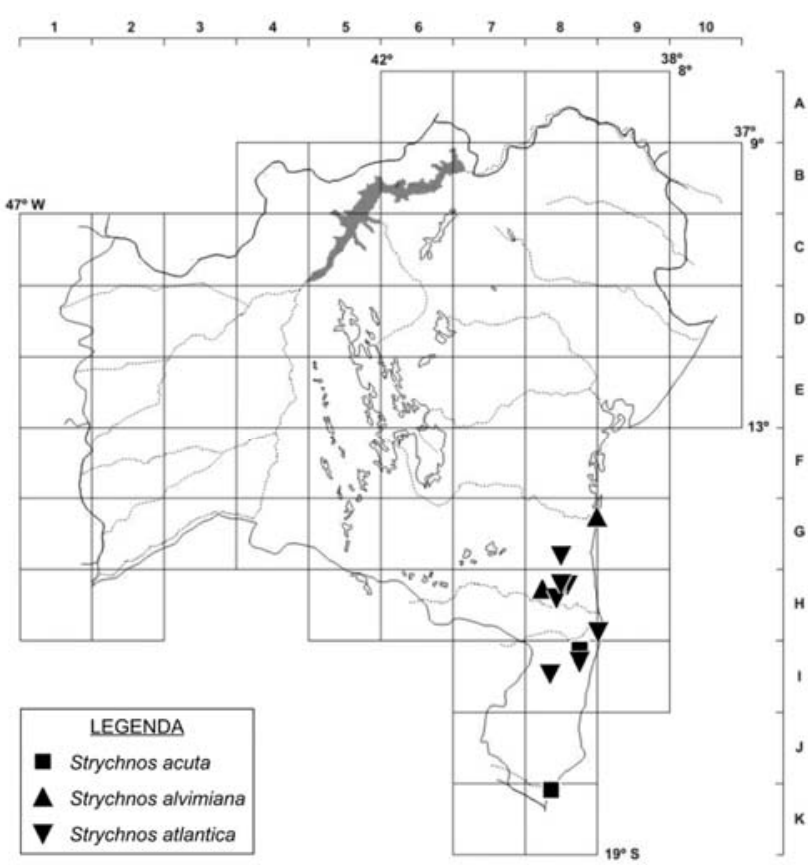

Figura 17. Mapa de distribuição de Strychnos acuta, S. alvimiana e S. atlantica no estado da Bahia.

Material adicional - BRASIL. ESPÍRITO SANTO: Km 22 da rodovia Linhares-Bananal, 24 nov. 1973 (fl.), R.S. Pinheiro 2281 (CEPEC).

Strychnos atlantica faz parte da seção Breviflorae. Trata-se de uma trepadeira ou liana de ramos delicados, geralmente glabros ou com indumento ferrugíneo a negrejante, folhas com pecíolo pubérulo a piloso e lâmina foliar completamente glabra, geralmente lustrosa em ambas as faces, nervuras primária e secundárias emersas na face adaxial e proeminentes na abaxial, assumindo uma coloração distinta da lâmina, e nervuras terciárias reticuladas. Produz bagas com casca coriácea, assemelhando-se à casca de uma laranja. Assemelha-se a S. acuta, S. erichsonii e $S$. recognita quando estéril, mas pode ser prontamente diferenciada pelas características mencionadas nos comentários daquelas espécies.

\subsection{Strychnos bahiensis Krukoff \& Barneby, Mem.} New York Bot. Gard. 20(1): 29. 1969. Figuras $18 \mathrm{~A}-\mathrm{F}, 19$ e $31 \mathrm{~K}$, L.

Liana, 5-25 m alt.; ramos castanhos a purpúreos, cilíndricos, pubérulos; lenticelas ausentes; gavinhas presentes. Folhas subsésseis ou pecíolo até $6 \mathrm{~mm}$ compr.; lâmina verde, amarelada quando seca, sutimente discolor, 3-9 × 2-5 cm, ovada, largo-ovada a elíptica, arredondada na base, acuminada a aguda no ápice, revoluta nas margens, cartácea a coriácea, esparso-pubérula a glabrescente em ambas as faces, triplinérvea. Tirsos terminais, laxos, 9-15 flores; pedúnculo 0,7-2 cm compr., glabro a minutamente pubérulo; brácteas 1-2 $\mathrm{mm}$ compr., lanceoladas, agudas a acuminadas no ápice, ciliadas nas margens. Flores com pedicelo 1-4 mm compr. Sépalas 1,2-1,5 × 0,6-0,8 mm, lanceoladas, acuminadas no ápice, ciliadas nas margens. Corola esverdeada com lobos púrpura, hipocrateriforme; tubo 10-14 $\mathrm{mm}$ compr., papiloso externamente, pubescente internamente; lobos 2-3 × 1-1,2 mm, ovados, papilosos externamente, pilosos para a base internamente. Estames exsertos; filetes $0,2-0,3 \mathrm{~mm}$ compr.; anteras $1-1,2 \mathrm{~mm}$ compr., dorsifixas, glabras. Ovário 1,2-1,4 mm compr.; estilete 12-14 mm compr.; estigma depresso-capitado. Bagas amarelas, 6,2-9,4× 6,5-9,5 cm; pericarpo sublenhoso, levemente rugoso. Sementes 8-15, 1-2,5 × 1-2 mm.

Endêmica do Brasil, ocorre da Bahia até Pernambuco (Krukoff \& Barneby 1969; Guimarães et al. 2017). F8, G7/8, G8, H8, H8/9 e I8: florestas ombrófilas denso-montanas e submontanas, florestas ciliares ou de galeria, em áreas preservadas ou perturbadas, no interior da mata, com pouca ou muita incidência luminosa direta. Floresce em abril e outubro e frutifica em fevereiro, julho e setembro.

Material selecionado - Arataca, $15^{\circ} 10^{\prime} 41^{\prime \prime} \mathrm{S}, 39^{\circ} 20^{\prime} 08^{\prime \prime} \mathrm{W}, 13$ set. 2009 (fr.), L. Daneu 135 (CEPEC); Cairu, 1329'12"S, 39²6'20"W, 25 out. 1984 (f1.), L.A.M. Silva \& T.S. Santos 1777 (ALCB, CEPEC, HUEFS, MBM); Camamu, $14^{\circ} 00^{\prime} 06^{\prime \prime} \mathrm{S}$, 39॰10'59"W, 21 fev. 2000 (fr.), J.G. Jardim et al. 2728 (CEPEC, HUEFS); Ilhéus, $14^{\circ} 47^{\prime} 20^{\prime \prime S}$, 39²9'38"W, 17 maio 1968 (est.), R.P. Belém 3581 (CEPEC); Itacaré, $14^{\circ} 16^{\prime} 39^{\prime \prime} \mathrm{S}, 39^{\circ} 59^{\prime} 48^{\prime \prime} \mathrm{W}, 7$ maio 1968 (est.), R.P. Belém 3510 (CEPEC); Ituberá, 1343'12"S, 3907'59"W, 29 nov. 2005 (est.), M.L. Guedes et al. 11934 (ALCB, CEPEC); Jussari, 15¹1'29"S, 39²9'43"W, 15 jun. 1968 (est.), R.P. Belém 3714 (CEPEC); Maraú, $14^{\circ} 06^{\prime} 11^{\prime \prime S}$, 3908'49"W, 10 out. 1968 (fl.), J.A. Jesus \& T.S. Santos 128 (CEPEC, MBM); Santa Cruz Cabrália, 16¹6'12"S, 39¹0'12"W, 3 abr. 1996 (fl.), M.L. Guedes et al. 6731 (ALCB); Una, 1509'S, 3949'W, 13 jul. 1993 (fr.), J.G. Jardim et al. 200 (CEPEC); Uruçuca, $14^{\circ} 25^{\prime} \mathrm{S}, 39^{\circ} 01^{\prime} \mathrm{W}$, 12 jul. 1991 (est), W.W. Thomas et al. 8645 (CEPEC).

Pertence à seção Longiflorae, cujas espécies são caracterizadas por apresentarem tirsos axilares e/ou terminais, corola hipocrateriforme, anteras com filete quase indistinto e folhas de coloração para o amareloocre quando secas. Strychnos bahiensis é facilmentes reconhecida pelas folhas esparso-pubérulas, glabrescente em ambas as faces, anteras exsertas e tubo alongado. Está relacionada a $S$. divaricans, diferindo pelas folhas lustrosas (vs. opacas), gavinhas lenhosas (vs. herbáceas) e corola menor (12-15,5 vs. 16-20 mm compr.). Quando estéril é possível ser confundida com $S$. gardneri (ver discussão mais detalhada naquela espécie) e S. trinervis; se diferencia da primeira por apresentar a axila das nervuras glabras (vs. barbada) e da segunda pelas folhas completamente glabras em ambas as faces (vs. pilosas a velutinas na face abaxial).

\subsection{Strychnos brasiliensis (Spreng.) Mart., Flora 24} (Belibl. 2): 84. 1841.

Figuras $18 \mathrm{G}-\mathrm{J}, 19$ e $31 \mathrm{M}, \mathrm{N}$.

Nome popular: esporão-de-galo e rompe-gibão.

Arvoreta a arbusto, 2-3,5 m alt.; ramos castanhoclaros, cilíndricos, glabros ou escabriúsculos a hirsutos; lenticelas pontiformes; espinhos e gavinhas presentes. Folhas subséssil ou pecíolo até $5 \mathrm{~mm}$ 
compr.; lâmina verde a verde-clara, mesmo quando secas, discolor, 1-6 × 1-2,5 cm, elíptica a ovadoelíptica, cuneada a arredondada na base, aguda a acuminada no ápice, papirácea a cartácea, esparsohirsuta na nervura central, pubérula ou glabra em ambas as faces, triplinérvea. Tirsos terminais, laxos, 12-40 flores; pedúnculo $0,5-1,2 \mathrm{~cm}$ compr., glabro ou glabrascente a minutamente pubérulo; brácteas $1-5 \mathrm{~mm}$ compr., lanceoladas, agudas no ápice, ciliadas nas margens. Flores com pedicelos 1,8-2 $\mathrm{mm}$ compr. Sépalas $0,8-1,5 \times 0,5-0,8 \mathrm{~mm}$, ovadas, cuneadas a levemente agudas, ciliadas nas margens. Corola branca, curto-infundibuliforme; tubo 1-1,5 mm compr., papiloso externamente, glabro internamente; lobos 1,8-2 $\times 1-1,5$ $\mathrm{mm}$, ovados, papilosos externamente, barbados internamente para a base. Estames semiexsertos; filetes 0,1-0,2 mm compr.; anteras 0,6-0,8 mm compr., basifixas, glabrescentes a esparso-pilosas na base. Ovário 0,6-0,9 mm compr.; estilete 0,8-1 mm compr.; estigma capitado. Bagas verdes a amarelas, 1,5-2 × 11,5 cm; pericarpo subcoriáceo, levemente rugoso. Sementes 2-4, 1-1,3 × 0,9-1,2 cm.

Ocorre na Argentina, Bolívia e Brasil. No Brasil, é encontrada na Bahia, Goiás, Mato Grosso do Sul, Minas Gerais, Rio de Janeiro, São Paulo, Paraná, Rio Grande do Sul e Santa Catarina (Krukoff \& Monachino 1942; Guimarães et al. 2017). D2, D5, D7, E6, E7, E9/10, F8, G7, I8 e J8: amplamente distribuída em florestas ciliares ou de galeria, florestas estacionais e ombrófilas, no interior de matas preservadas ou em áreas antropizadas, na borda de trilhas. Floresce de novembro a fevereiro e frutifica principalmente em setembro e outubro.

Material selecionado - Baixa Grande, $11^{\circ} 52^{\prime} 25^{\prime \prime} \mathrm{S}, 40^{\circ} 06^{\prime} 18^{\prime \prime} \mathrm{W}, 2$ set. 1980 (fr.), R.P. Orlandi 289 (ALCB, CEPEC, RB); Barra do Mendes, $11^{\circ} 49^{\prime} 39^{\prime \prime} \mathrm{S}, 42^{\circ} 08^{\prime} 11^{\prime \prime} \mathrm{W}, 25$ out. 2009 (est.), E. Melo et al. 6854 (ALCB, HUEFS); Entre Rios, 12³0'S, 38 $00^{\prime} \mathrm{W}, 27$ fev. 2010 (est.), A.V. Popovkin \& J.C. Mendes 667 (HUEFS); Formosa do Rio Preto, $11^{\circ} 22^{\prime} 09^{\prime \prime} \mathrm{S}, 45^{\circ} 18^{\prime} 29^{\prime \prime W}, 26$ abr. 1990 (est.), H.P. Bautista 1506 (RB); Itaberaba, $12^{\circ} 31^{\prime} 39^{\prime \prime} \mathrm{S}, 40^{\circ} 18^{\prime} 24^{\prime \prime} \mathrm{W}, 13$ nov. 1983 (fl.), G.C.P. Pinto et al. 392 (ALCB, CEPEC, HUEFS, RB); Jacobina, 11 ${ }^{\circ} 10^{\prime} 50 " \mathrm{~S}$, 40³1'58"W, 21 fev. 1993 (fr.), A.M. Amorim et al. 1002 (CEPEC); Lençóis, 12³9'00"S, 41 ${ }^{\circ} 19^{\prime} 12^{\prime \prime W}, 29$ jan. 1997 (est.), S. Atkins et al. 4670 (ALCB, HUEFS); Miguel Calmon, 11²6'26"S, 40³2'57"W, 23 dez. 2006 (est.), M.L. Guedes et al. 13288 (ALCB); Poções, 14²7'S, 40²8'W, 16 mar. 1984 (est.), J.E.M. Brazão 279 (RB); Porto Seguro, 16²6'58"S, 39³8'49"W, 13 out. 1983 (fr.), G. Martinelli \& T. Soderstrom 9638 (CEPEC, RB); Prado, 17¹5'S, 39 $15^{\prime} \mathrm{W}, 20$ out. 1993 (fr.), W.W. Thomas et al. 10002 (CEPEC); Ruy Barbosa, 12²0'07"S, 40²8'30"W, 26 mar. 2005 (est.), D. Cardoso et al. 361 (HUEFS).

Segundo Krukoff \& Monachino (1942), Strychnos brasiliensis apresenta ampla variação morfológica, incluindo quatro variedades e oito espécies em sua sinonímia. É reconhecida pela presença de espinhos geralmente curvos e lenhosos (daí seu nome popular), ramos completamente lenticelados, folhas geralmente elípticas, membranáceas, papiráceas ou cartáceas, agudas a acuminadas no ápice, com nervuras primária e secundárias emersas na face abaxial, levemente proeminentes na adaxial, e as inflorescências laxas (vs. congestas nas demais espécies). Ducke (1965) relata a semelhança da espécie com S. mattogrossensis, mas ambas podem ser facilmente diferenciada pelas bagas globosas ou subglobosas, suculentas (vs. fibrosas), lisa (vs. rugosa), com sementes discoides ou esféricas de 1-2 cm compr. (vs. 2-2,5 cm).

3.6. Strychnos divaricans Ducke, Bull. Mus. Natl. Hist. Nat., sér. 2, 4: 746. 1932.

Figuras $18 \mathrm{~K}-\mathrm{M}, 19$ e 310.

Trepadeira; ramos castanho-acinzentados, cilíndricos, glabros; lenticelas ausentes; gavinhas presentes. Folhas subsésseis ou pecíolo 3-7 $\mathrm{mm}$ compr.; lâmina verde-oliva a castanho-amarelada quando seca, discolor, 3,5-8 × 1,5-3,6 cm, ovadoelíptica, arredondada a cuneada na base, acuminada no ápice, revoluta nas margens, cartácea a subcoriácea, glabra em ambas as faces, triplinérvea. Tirsos terminais, laxos, 9-30 flores; pedúnculo 2-4,4 cm compr., glabro; brácteas 0,5-2 $\mathrm{mm}$ compr., lanceoladas, agudas a acuminadas no ápice, ciliadas nas margens. Flores subsésseis ou pedicelo $2-5 \mathrm{~mm}$ compr. Sépalas $1-1,2 \times 0,8-1 \mathrm{~mm}$, ovado-deltoides, agudas no ápice, ciliadas nas margens. Corola amareloesverdeada a amarela, hipocrateriforme; tubo 13-14(16) $\mathrm{mm}$ compr., glabro a papiloso externamente, piloso a densamente piloso na fauce internamente; lobos 4 4,5 × 0,8-1 mm, lanceolados a oblanceolados, glabros a papilosos externa e internamente. Estames inclusos; filetes 1,5-2 mm compr.; anteras 1-1,2 mm compr., dorsifixas, glabras. Ovário 1-1,2 mm compr.; estilete 16,5-18 mm compr.; estigma depresso-capitado. Bagas não vistas. Sementes não vistas.

Ocorre na Guiana Francesa, Suriname e Brasil. No Brasil, é citada para os estados do Amazonas, Amapá, Pará, Bahia, Ceará, Maranhão, Paraíba, Pernambuco, Piauí e Rio Grande do Norte (Krukoff \& Monachino 1942; Guimarães et al. 2017). F7: florestas ombrófilas denso-montanas, ciliares ou de galeria, na borda da mata, em áreas pertubadas sob pouca incidência luminosa. Foi coletada com flor em novembro.

Material examinado - Maracás, $13^{\circ} 26^{\prime} 27^{\prime \prime} \mathrm{S}, 40^{\circ} 25^{\prime} 50^{\prime \prime} \mathrm{W}, 18$ nov. 1978 (fl.), S.A. Mori et al. 11177 (CEPEC, RB).

Material adicional - BRASIL. PARÁ: Juriti Velho, 19 dez. 1926 (fl.), A. Ducke s.n. (holótipo de S. divaricans: RB 22362).

Strychnos divaricans possui ramos delgados com gavinhas herbáceas, folhas glabras, lustrosas, com nervuras planas na face adaxial e proeminentes a levemente proeminentes na abaxial, corola glabra a papilosa, alongada (17-20 $\mathrm{mm}$ compr.) e estigma glabro. Pode ser facilmente reconhecida dentre as espécies de Strychnos que ocorrem na Bahia pela corola grande (mais que $16 \mathrm{~mm}$ vs. menos que 15,5 mm compr.). Segundo Krukoff \& Monachino (1942), S. divaricans é afim de $S$. panamensis e $S$. tabascana, diferindo delas pelas sépalas largo-ovadas, de 1-1,2 mm compr. (vs. lanceolada, com mais de 2,5 $\mathrm{mm}$ compr.). 


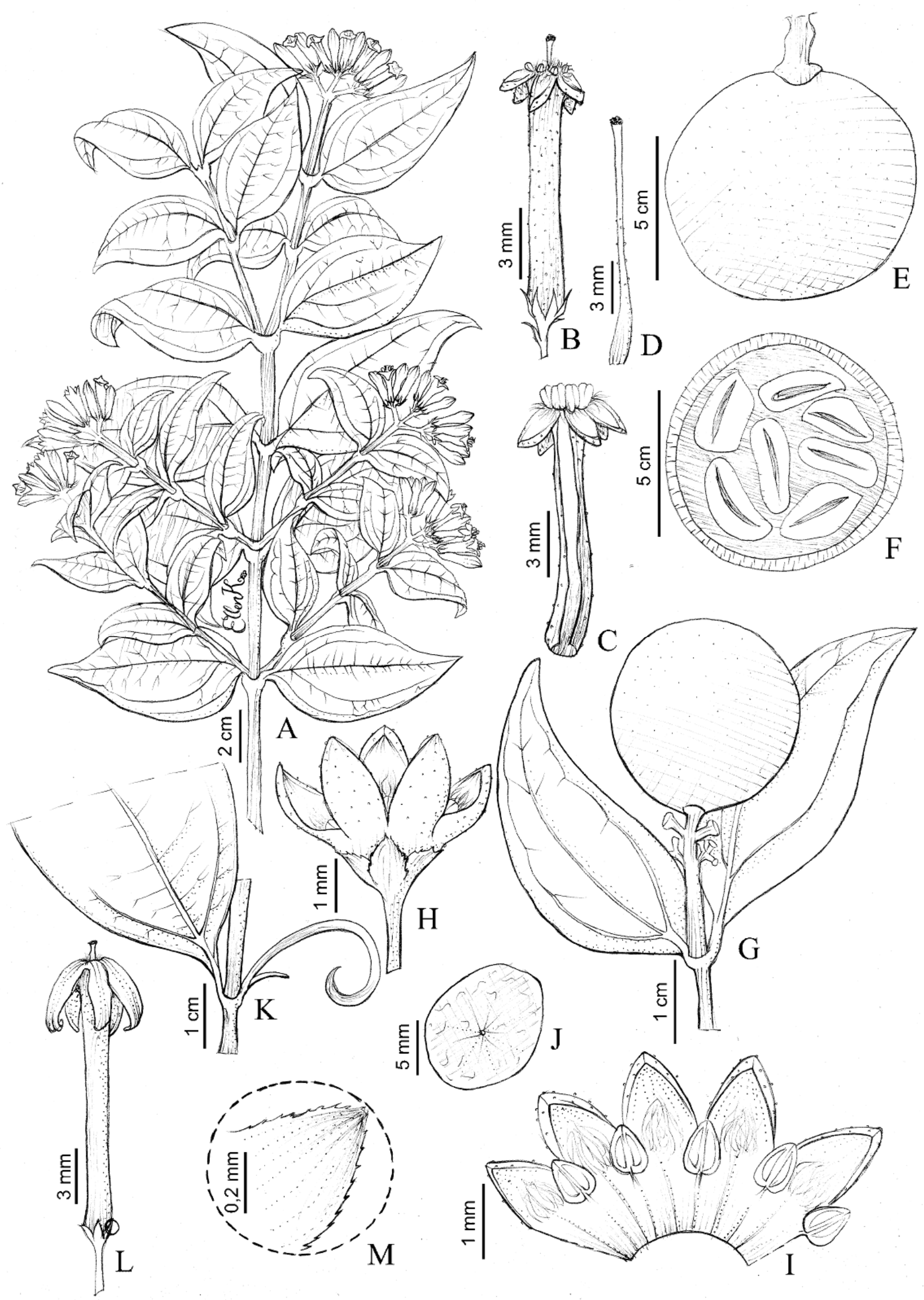

Figura 18. A-F. Strychnos bahiensis: A- ramo fértil, com tirsos terminais; B- flor; C- corola aberta; D- pistilo; E- baga; F- baga, corte transversal, expondo o pericarpo e as sementes. G-J. S. brasiliensis: G- ápice do ramo com baga; H- flor; I- corola aberta; J- semente, vista ventral. K-M. S. divaricans: K- nó do ramo, estípula linear e gavinha herbácea; L- flor; M- detalhe da sépala com margens ciliadas. (A-F- Almeida 128; E-F- Guedes 11934; G- Melo 4310; H, I- Popovkin 667; J- Melo 4310; K-M- Mori 11177). 


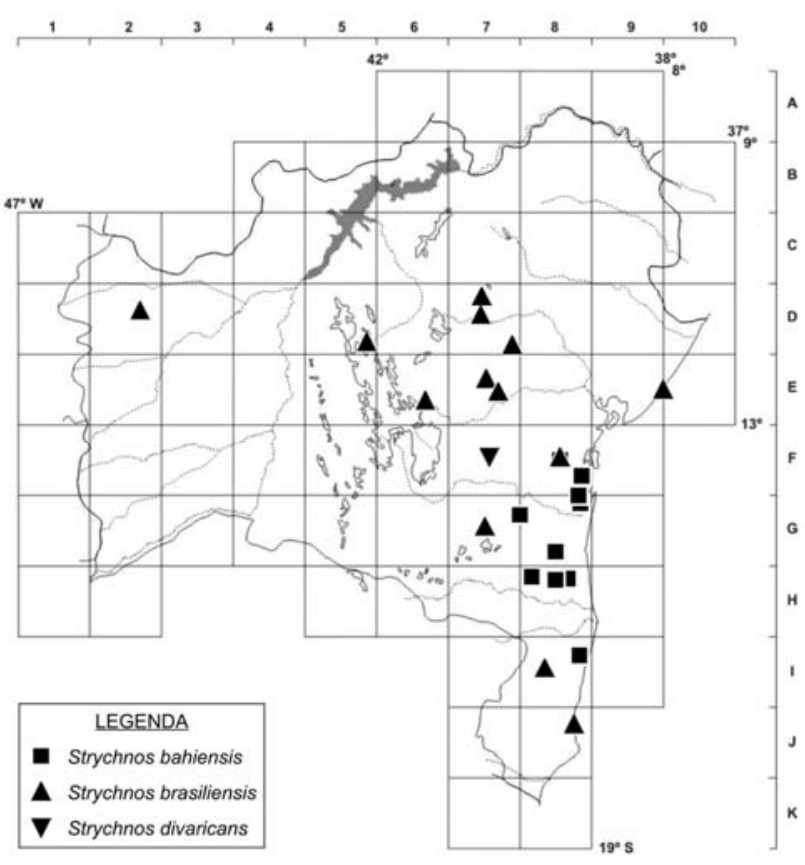

Figura 19. Mapa de distribuição de Strychnos bahiensis, S. brasiliensis e $S$. divaricans no estado da Bahia.

3.7. Strychnos erichsonii R.H. Schomb. ex. Progel in Martius, Fl. Bras. 6(1): 274. 1868.

Figuras 20A-D, 21 e 32A.

Trepadeira; ramos castanho-escuros, cilíndricos, glabros ou curto-pubérulos próximo aos nós; lenticelas ausentes; gavinhas presentes. Folhas com pecíolo 3-10 mm compr.; lâmina verde a castanho-amarelada quando seca, discolor, 4-10 × 1,6-5 cm, elíptica a oblonga, cuneada a arredondada na base, acuminada no ápice, revoluta ou não nas margens, subcoriácea a coriácea, glabra em ambas as faces ou puberula na face abaxial, triplinérvea, raro quintuplinérvea. Tirsos terminais e/ou axilares, laxos ou congestos, 9-12 flores; pedúnculo até $1,5 \mathrm{~cm}$ compr., pubescente; brácteas $0,8-5 \mathrm{~mm}$ compr., ovadas, acuminadas a agudas no ápice, ciliadas nas margens. Flores sésseis ou pedicelo até $3 \mathrm{~mm}$ compr. Sépalas $0,8-1 \times 0,4-0,6$ $\mathrm{mm}$, ovadas a deltoides, agudas no ápice, ciliadas nas margens. Corola creme a amarela, hipocrateriforme; tubo 6,5-8 mm compr., papiloso externamente, piloso internamente; lobos (2,5-)3-4 × (0,8-)1-1,2 mm, lanceolados a estreito-ovados, papilosos externamente, barbados para a base internamente. Estames semiexsertos; filetes 0,2-0,3 mm compr.; anteras ca. 1 mm compr., basifixas, glabras. Ovário 1-1,5 $\mathrm{mm}$ compr.; estilete 9-10,5 mm compr.; estigma capitado, adpresso. Bagas amarelo-ocre, 4,5-6 × 4,2-5,5 cm; pericarpo fibroso, levemente rugoso a liso. Sementes $6-10,1,5-2,5 \times 1,3-1,5 \mathrm{~cm}$ [bagas e sementes não vistas; informações obtidas no protólogo].

Ocorre na Bolívia, Brasil, Colômbia, Equador, Guiana, Guiana Francesa, Panamá, Peru, Suriname e Venezuela. No Brasil, ocorre nos estados do Acre, Amazonas, Amapá, Pará, Rondônia, Bahia, Maranhão, Mato Grosso do Sul, Mato Grosso (Krukoff \&
Monachino 1942; Guimarães et al. 2017). G8: florestas ombrófilas montanas e submontanas, na borda ou interior da mata. Encontrada com flores entre abril e junho.

Material selecionado - Maraú, $14^{\circ} 06^{\prime} 11^{\prime \prime} \mathrm{S}, 39^{\circ} 08^{\prime} 49^{\prime \prime} \mathrm{W}, 29$ abr. 1968 (fl.), R.P. Belém 3460 (CEPEC).

Material adicional - BRASIL. AMAZONAS: Humaitá, 26 nov. 1966 (fr.), G.T. Prance 3352 (RB). PARÁ: beira dos rios Irituia e Guamá, 22 ago. 1948 (fl.), A.G. Black 48/3140 (ALCB).

Strychnos erichsonii é caracterizada por ser uma trepadeira com ramos e pecíolos glabros ou pubérulos, folhas opacas a pouco lustrosas, sépalas diminutas em relação ao comprimento da corola e tubo da corola internamente piloso na porção superior, concentrandose na fauce. Assemelha-se a S. mitscherlichii e $S$. peckii na fase reprodutiva (veja comentário naquelas espécies). Quando estéril assemelha-se a S. alvimiana e S. atlantica, sendo diferenciada dessas espécies pelas folhas verde-ocre a amarelo-ocre (vs. verdeacinzentadas ou castanhas) quando secas, nervuras planas em ambas as faces (vs. proeminentes na face abaxial).

3.8. Strychnos gardneri A.DC. in A.P. de Candolle, Prodr. 9: 14. 1845.

Figuras 20E-K, 21 e 32B, C.

Arbusto escandente a liana, até $7 \mathrm{~m}$ alt.; ramos castanhos, cilíndricos, pubérulos; lenticelas ausentes; espinhos e gavinhas ausentes. Folhas subsésseis ou pecíolo até $1 \mathrm{~cm}$ compr.; lâmina verde a verdeamarelada quando seca, discolor, 7-11 × 3,5-7,6 cm, ovado-oblonga a largo-ovada, cuneada a arredondada na base, aguda no ápice, coriácea, glabra abaxialmente, domácias bardado-hirsutas nas axilas das nervuras principais, quintuplinérvea, raro triplinérvea. Tirsos terminais e axilares, laxos ou congestos, 15-33 flores; pedúnculo ca. 1,5 cm compr., densamente pubescente; brácteas 2-5 $\mathrm{mm}$ compr., lanceoladas, agudas a acuminadas no ápice, ciliadas nas margens. Flores sésseis ou pedicelos até $1,5 \mathrm{~mm}$ compr. Sépalas $1,5-$ $2,0 \times 0,8-1 \mathrm{~mm}$, ovadas, cuneadas a levemente agudas no ápice, ciliadas nas margens. Corola amarela, hipocrateriforme; tubo 5-6 $\mathrm{mm}$ compr., pubérulo externamente, piloso internamente; lobos 2,5-3 × 0,8$1 \mathrm{~mm}$, ovados, glabrescentes a denso-pubérulos externamente, piloso internamente na base. Estames semiexsertos; filetes até $0,1 \mathrm{~mm}$ compr.; anteras $0,8-1$ $\mathrm{mm}$ compr., dorsifixas, glabras. Ovário 0,8-1 $\mathrm{mm}$ compr.; estilete 5,5-6 mm compr.; estigma depressocapitado. Bagas amarelas, 2-2,5 × 1,5-1,8 cm; pericarpo subcoriáceo, levemente rugoso a liso. Semente 1(2), 1-1,5 × 1,2-1,5 cm.

Ocorre na Bolívia e no Brasil, nos estados do Pará, Tocantins, Bahia, Ceará, Maranhão, Pernambuco, Goiás, Mato Grosso, Espírito Santo, Minas Gerais, Rio de Janeiro, São Paulo (Krukoff \& Monachino 1942; Guimarães et al. 2017). B5/6, D5 e D7: florestas ombrófilas denso montanas e submontanas, matas ciliares e florestas estacionais deciduais, em borda da 
mata, geralmente em áreas com incidência luminosa. Coletada com flores em outubro e frutos em junho, setembro e outubro.

Material examinado - Barra do Mendes, 11\%49'39"S, 42 ${ }^{\circ} 11 " \mathrm{~W}, 25$ out. 2009 (fr.), E. Melo et al. 6854 (HUEFS); Ipupiara, $11^{\circ} 50^{\prime} 08^{\prime \prime S}, 42^{\circ} 28^{\prime} 00^{\prime \prime} \mathrm{W}, 12$ jun. 2015 (fr.), M.L. Guedes et al. 23540 (ALCB); Irecê, $11^{\circ} 48^{\prime} 27^{\prime \prime S}, 42^{\circ} 14^{\prime} 05^{\prime \prime} \mathrm{W}, 25$ out. 2009 (fl.), F.S. Gomes et al. 311 (ALCB, HUEFS); Jacobina, $11^{\circ} 09^{\prime} 46^{\prime \prime S}, 40^{\circ} 29^{\prime} 49^{\prime \prime W}, 20$ set. 2009 (fr.), M.L. Guedes et al. 14825 (ALCB); Remanso, 09²0'20"S, 41 $58^{\circ} 48^{\prime \prime} \mathrm{W}, 23$ set. 2009 (est.), M.L. Guedes et al. 16049 (ALCB, HUEFS).

Strychnos gardneri apresenta ampla distribuição no Brasil e pode ser facilmente reconhecida por apresentar lâmina foliar glabra, lustrosa adaxialmente e opaca abaxialmente, com acarodomácia nas axilas das nervuras secundárias; inflorescências terminais e axilares, corola amarela e bagas amarelas, com pericarpo fino. É semelhante a S. bahiensis quando estéril, devido às folhas glabras, lustrosas na face abaxial, coriáceas a subcoriáceas, ficando verdes, castanhas ou amarelo-ocre quando secas. Todavia, $S$. gardneri apresenta a axila das nervuras secundárias hirsutas (vs. glabra), inflorescências axilares e terminais (vs. apenas terminais), tubo da corola pubérulo externamente (vs. papiloso) e menor (5-6 mm vs. 10-14 mm compr.).

3.9. Strychnos mattogrossensis S.Moore, Trans. Linn. Soc. London, Bot. 4: 392. 1895.

Figuras 20L-O, 21 e 32D.

Trepadeira ou arbusto, 2-5 m alt.; ramos castanhos a acinzentados, cilíndricos a subtetrágonos, glabros; lenticelas pontiformes; gavinhas e espinhos presentes. Folhas subsésseis ou pecíolo até $6 \mathrm{~mm}$ compr.; lâmina verde a negrejante quando seca, discolor, 3-7 × 1,5$3,7 \mathrm{~cm}$, elíptica a ovada, cuneada a arredondada na base, acuminada no ápice, membranácea a papirácea (cartácea), glabra a pubescente em ambas as faces, triplinérvea, raro quintuplinérvea. Tirsos terminais, laxos ou congestos, 6-40(50) flores; pedúnculo 0,5-2 cm compr., glabro a pubérulo; brácteas $0,3-4 \mathrm{~mm}$ compr., linear-lanceoladas, agudas no ápice, ciliadas nas margens. Flores subsésseis ou pedicelo até $0,2 \mathrm{~mm}$ compr. Sépalas $0,5-0,8 \times 0,2-0,3 \mathrm{~mm}$, ovadas, agudas no ápice, ciliadas nas margens. Corola verde-clara a amarela, curto-infundibuliforme; tubo 0,6-0,8 $\mathrm{mm}$ compr., minutamente papiloso externamente, glabro internamente; lobos $1-1,5 \times 0,5-0,8 \mathrm{~mm}$, ovados, minutamente papilosos externamente, barbados para o ápice internamente. Estames semiexsertos; filetes ca. 0,2 mm compr.; anteras ca. 0,6 mm compr., basifixas, pilosas na base. Ovário $0,3-0,5 \mathrm{~mm}$ compr.; estilete 0,7-0,8 mm compr.; estigma capitado. Bagas amarelas, $2-2,5 \times 2-2,3 \mathrm{~cm}$; pericarpo fibroso, rugoso. Semente $1(2), 1-1,2 \times 0,8-1$.

Ocorre na Bolívia, Brasil, Colômbia, Peru e Venezuela. No Brasil, é encontrada nos estados do Acre, Amazonas, Pará, Bahia, Ceará, Maranhão, Paraíba, Pernambuco, Rio Grande do Norte, Mato
Grosso do Sul, Mato Grosso (Krukoff \& Monachino 1942; Guimarães et al. 2017). B/C8, C9, D5, D7, F3, G5, G8, G8/9, H8 e H8/9: florestas ombrófilas densomontanas e submontanas, florestas ciliares ou de galeria e florestas estacionais semideciduais, em áreas com sombreamento parcial, no interior ou na borda da mata. Floresce de janeiro a fevereiro e frutifica em março, junho e setembro.

Material selecionado - Banzaê, $10^{\circ} 39^{\prime} 10^{\prime \prime} \mathrm{S}, 38^{\circ} 40^{\prime} 23^{\prime \prime} \mathrm{W}, 22$ set. 2002 (fr.), C. Correia et al. 172 (HUEFS); Belmonte, 1551'47"S, 38॰52'58"W, 30 set. 1977 (est.), T.S. Santos 3141 (CEPEC); Caetité, 1441'38"S, 42²8'30"W, 20 mar. 1980 (fr.), S.A. Mori \& F. Benton13486 (CEPEC); Itacaré, 14²16'39"S, $38^{\circ} 59^{\prime} 48^{\prime \prime W}, 2$ set. 1970 (fr.), T.S. Santos 1062 (CEPEC); Jacobina,

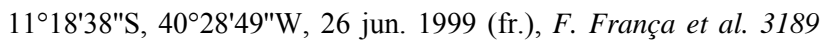
(HUEFS); Maraú, 1406'11"S, 3908'49"W, 13 jan. 1967 (fl.), R.P. Belém \& R.S. Pinheiro3110 (CEPEC); Santa Luzia, $15^{\circ} 25^{\prime} 45^{\prime \prime}$, 39²0'31"W, 23 jul. 1996 (est.), J.G. Jardim et al. 859 (CEPEC, RB); São Félix do Coribe, $13^{\circ} 33^{\prime} 18^{\prime \prime} \mathrm{S}, 4^{\circ} 07^{\prime} 27^{\prime \prime W}, 11$ jan. 2008 (fl.), A. Rapini et al. 1479 (HUEFS); São Miguel das Matas, $10^{\circ} 02^{\prime} 54^{\prime \prime S}, 39^{\circ} 25^{\prime} 55^{\prime \prime W}, 24$ fev. 2000 (fl.), J.G. Jardim et al. 2894 (HUEFS).

Material adicional - BRASIL. MATO GROSSO: 1 jan. 1891, (fl.), S.A Moore 675 (tipo de S. mattogrossensis: NY [foto]).

$\mathrm{Na}$ descrição original, Strychnos mattogrossensis foi caracterizada por apresentar ramos pubescentes a puberulentos, com espinhos curtos ou alongados, retos a curto-recurvados, com gavinhas herbáceas curvas, folhas membranáceas, ovadas, glabras, e inflorescências laxas, terminais. Assemelha-se a $S$. nigricans e $S$. brasiliensis pelo hábito, de arbustivo escandente a trepadeira, e pela morfologia geral. Distingue-se de $S$. brasiliensis pelos espinhos retos a pouco curvados (vs. longamente curvados) e pelas gavinhas (vs. ausente), e de ambas as espécies pelas bagas fibrosas (vs. subcoriáceas).

3.10. Strychnos mitscherlichii M.R.Schomb., Reis. Br.-Guiana 3: 950. 1848 [1849].

Figuras 22A, B, 23 e 32E, F.

Liana; ramos castanhos a acinzentados; cilíndricos, glabros a puberulentos; lenticelas ausentes; gavinhas presentes. Folhas subsésseis ou pecíolo 3-10 $\mathrm{mm}$ compr.; lâmina verde, castanho-avermelhada a amarelada quando seca, discolor, 4-15 × 3-10 cm, elíptica a ovada, redonda a cuneada na base, largoacuminada a cuneada no ápice, inteira nas margens, coriácea a subcoriácea, glabra em ambas as faces, triplinérvea ou quintuplinérvea. Tirsos terminais e axilares, congestos, 15-50 flores; pedúnculo 1,6-1,8 cm compr., pubérulo a glabro; brácteas $1-1,2 \mathrm{~mm}$ compr., ovadas, ciliadas nas margens. Flores subsésseis ou pedicelo 1-1,2 mm compr. Sépalas 1-1,2 $\times$ ca. $0,8 \mathrm{~mm}$, ovadas a ovado-lanceoladas, cuneadas no ápice, ciliadas nas margens. Corola amarela, hipocrateriforme; tubo 7,3-7,8 $\mathrm{mm}$ compr., glabro a papiloso externamente, densamente piloso internamente; lobos 3-3,5 × 1-1,4 mm, ovados, papilosos externamente, pilosos na base internamente. 


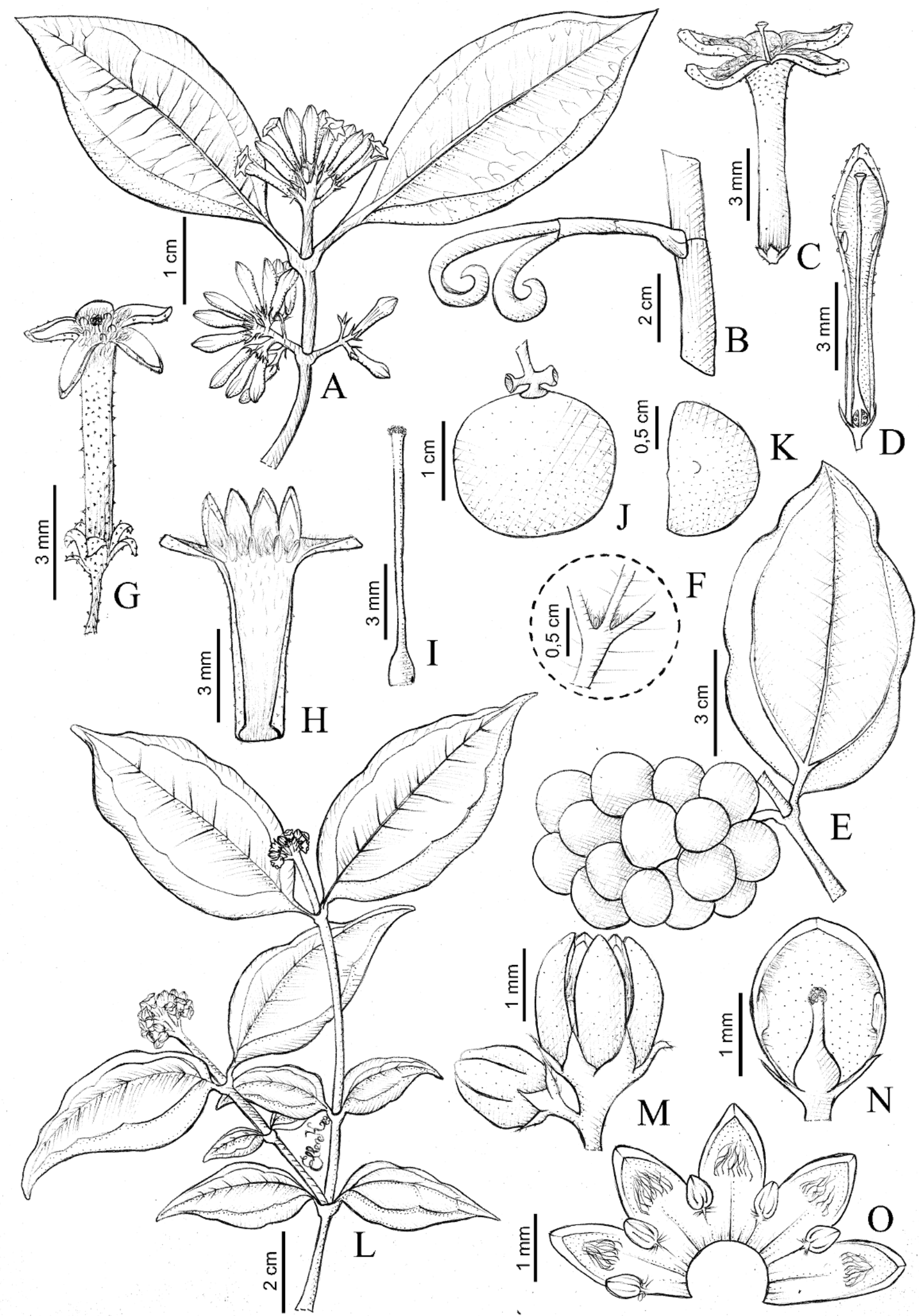

Figura 20. A-D. Strychnos erichsonii: A- porção do ramo, tirsos terminal e axilares; B- nó do ramo, com gavinhas sublenhosas; C- flor; D- botão em corte longitudinal. E-K. S. gardneri: E- nó do ramo, infrutescência; F- domácias em detalhe na axila das nervuras da face abaxial da folha; G- flor; H- corola aberta, vista interna; I- pistilo; J- baga; K- semente, vista ventral. L-O. S. mattogrossensis: L- ramo fértil; M- flor e botão; N- flor em corte longitudinal; O- corola aberta. (A-D- Belém 3497; E, F- Guedes 23540; G-I- Lombardi 4666; J-K- Guedes 23540; L-O- Belém 3110). 


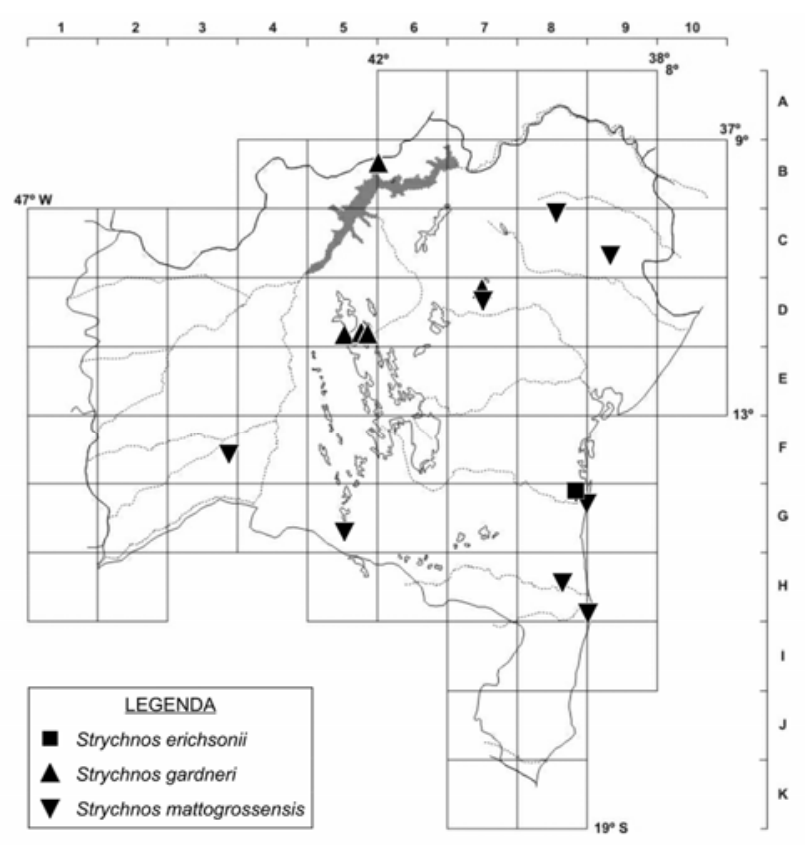

Figura 21. Mapa de distribuição de Strychnos erichsonii, S. gardneri e S. mattogrossensis no estado da Bahia.

Estames inclusos; filetes até $0,2 \mathrm{~mm}$ compr.; anteras 0,8-1 mm compr., basifixas, glabras. Ovário 1,5-2 mm compr.; estilete 8-8,5 mm compr., estigma depressocapitado. Bagas amarelas, 3,5-4,3 × 3,5-3,9 cm; pericarpo subcoriáceo a fibroso, rugoso. Sementes 2-8, 1,5-2 × 1,2-1,6 mm [bagas não vistas; informações obtidas de Krukoff \& Monachino 1942].

Ocorre na Bolívia, Brasil, Colômbia, Equador, Guiana, Guiana Francesa, Peru, Venezuela e Suriname. No Brasil, ocorre nos estados do Acre, Amazonas, Amapá, Pará, Rondônia, Bahia e Rio Grande do Norte (Krukoff \& Monachino 1942; Guimarães et al. 2017). G8: florestas ombrófilas denso-montanas e submontanas, em solos argilosos de terra firme, ricos em húmus, no interior da mata.

Material examinado - Ilhéus, $1^{\circ} 56^{\prime} 57^{\prime \prime} \mathrm{S}, 39^{\circ} 01^{\prime} 12^{\prime \prime} \mathrm{W}, 2$ abr. 1943 (est.), R. Lemos Fróes 12724 (NY [foto]); Uruçuca, 14²5'23"S, 39³6'20"W, 8 maio 1995 (est.), W.W. Thomas et al. 10825 (CEPEC).

Material adicional - BRASIL. PARÁ: São Miguel, 21 ago. 1941, (f1.), D. Dardano 48/3082 (ALCB). GUIANA. BARAMA RIVER: British Guiana, s.d. (est.), R.H. Schomburgk 777/1516B (holótipo de S. mitscherlichii: K [foto]).

Strychnos mitscherlichii é caracterizada por ser uma liana com folhas geralmente castanho-avermelhadas a amarelas quando secas, glabras, e nervuras reticuladas proeminente em ambas as faces, lobos do cálice ovado a ovado-lanceolados, tubo da corola glabro a papiloso externamente e bagas achatadas transversalmente. A publicação da espécie foi feita com base em material estéril e só teve suas partes vegetativas descritas posteriormente pelos autores supracitados. Assemelhase a $S$. solimoesana (ver comentários em $S$. solimoesana) e $S$. erichsonii, podendo ser distinta pela lâmina foliar, com o segundo par de nervuras surgindo bem acima da base (vs. nervuras secundárias surgindo na base ou próximas a ela), oblonga a elíptico-oblonga (vs. elípticas a ovado-elípticas), oliva-ocre a castanhoavermelhada (vs. amerelo-ocre), inflorescências axilares apenas (vs. terminais e axilares), cálice maior (1-1,2 mm vs. $0,8-1 \mathrm{~mm}$ compr.) e estilete mais longo (9-10 mm vs. estilete $8-8,5 \mathrm{~mm}$ compr.).

\subsection{Strychnos nana E.Brandão, Phytotaxa 329(3): 263.}

Figuras 22C-I, 23 e $32 \mathrm{G}$.

Erva ereta a subarbusto, 0,3-0,4 $\mathrm{m}$ alt.; ramos castanho-claros, cilíndricos, pubescentes; lenticelas ausentes; espinhos e gavinhas ausentes. Folhas sésseis ou pecíolo até $2 \mathrm{~mm}$ compr.; lâmina verde a castanhonegrejante quando seca, concolor, $0,7-1,1 \times 0,3-1,1 \mathrm{~cm}$, ovada a largo-ovada, subcordada a cordada na base, arredondada a retusa no ápice, geralmente espessada e ciliada nas margens, coriácea a subcoriácea, glabra em ambas as faces, quintuplinérvea. Tirsos terminais, congestos, 9-12 flores; pedúnculo até 0,5 cm compr., pubérulo; brácteas $0,5-2(-2,5) \mathrm{mm}$ compr., deltoides, agudas no ápice, ciliadas nas margens. Flores com pedicelo até $1 \mathrm{~mm}$ compr. Sépalas verdes, $0,8-1 \times$ ca. $0,8 \mathrm{~mm}$, largo-ovadas, acuminadas no ápice, esparsociliadas nas margens. Corola branca a verde-clara, curtoinfundibuliforme; tubo $0,8-1 \mathrm{~mm}$ compr., papiloso externamente, glabro internamente; lobos 2-2,5 × $0,8-$ $1,3 \mathrm{~mm}$, ovados, papilosos externamente, barbados para a base internamente. Estames exsertos; filetes 0,2-0,3 $\mathrm{mm}$ compr.; anteras 0,7-0,8 $\mathrm{mm}$ compr., basifixas, glabras. Ovário 0,7-0,8 mm compr.; estilete 0,5-0,6 mm compr.; estigma capitado. Bagas imaturas, 0,5-0,8 $\times$ 0,6-0,8 cm; pericarpo suculento, minutamente rugoso. Sementes não vistas.

Ocorre nos estados de Tocantins e Bahia (Brandão \& Rapini 2017). F3: campos sujos e cerrados, crescendo exposta ao sol, em solos arenosos. Encontrada com flores em outubro, após queimada.

Material examinado - Correntina, $13^{\circ} 25^{\prime} 20^{\prime \prime} \mathrm{S}, 44^{\circ} 40^{\prime} 44^{\prime \prime} \mathrm{W}$, 31 out. 2009, (fl.), J.G. Freitas et al. 559 (HUEFS).

Material adicional - BRASIL. TOCANTINS: Ponte Alta do Tocantins, $10^{\circ} 45^{\prime} 36^{\prime \prime S}, 47^{\circ} 31^{\prime} 12^{\prime \prime} \mathrm{W}, 19$ nov. 2008 (fl., fr.), C.W. Fagg \& F.C.A. Oliveira 3671 (HUEFS); ib., 10²6'39"S, 4709'27"W, 8 nov. 2009 (fl.), E. Melo et al. 7150 (HUEFS).

Strychnos nana varia de erva a subarbusto de pequeno porte, com flores tetrâmeras em ramos laterais e pentâmeras nos ramos apicais. É similar a $S$. parvifolia e $S$. rubiginosa, as quais apresentam ampla distribuição, ocorrendo também no cerrado. As três espécies compartilham características reprodutivas, como corola curto-infundibuliforme e frutos com pericarpo suculento. Mas $S$. nana pode ser diferenciada pelo hábito reduzido (menor que $40 \mathrm{~cm}$ vs. maior que $50 \mathrm{~cm}$ de altura), ramos inermes (vs. com espinhos em S. parvifolia), folhas reduzidas (até cerca de $1 \mathrm{~cm}$ vs. 2-8,5 cm compr.), espessadas nas margens (vs. não espessadas) e tirsos menores (raramente alcançando 1 cm vs. 1-5,5 cm compr.), com menor quantidade de flores (9-12 vs. 15-50). 
3.12. Strychnos nigricans Progel in Martius, Fl. Bras. 6(1): 280. 1868.

Figura 22J-L, 23 e $32 \mathrm{H}$.

Arbusto escandente, ca. 2 m alt.; ramos castanhoacinzentados a negrejantes, cilíndricos, pilosos a pubescentes quando jovens, glabrescentes; lenticelas pontiformes; espinhos e gavinhas presentes. Folhas subsésseis ou pecíolo até $5 \mathrm{~mm}$ compr.; lâmina verdeoliva a negrejante quando seca, discolor, 2-6,5 × 1-3,5 $\mathrm{cm}$, ovado-elíptica a elíptica, arredondada a cuneada na base, acuminada, aguda ou arredondada no ápice, inteira nas margens, membranácea a papirácea, glabra a hirsuta em ambas as faces, triplinérvea. Tirsos terminais, laxos ou raramente congestos, 9-16 flores; pedúnculo $0,5-1,6 \mathrm{~cm}$ compr., piloso a densopubescente; brácteas $2-5 \mathrm{~mm}$ compr., ovadolanceoladas a lanceoladas, acuminadas no ápice, ciliadas nas margens. Flores com pedicelo $2-3 \mathrm{~mm}$ compr. Sépalas $1-1,8 \times 0,6-0,8 \mathrm{~mm}$, ovadolanceoladas, agudas no ápice, ciliadas nas margens. Corola branca a verde-clara, curto-infundibuliforme; tubo 1,2-1,5 $\mathrm{mm}$ compr., minutamente papiloso externamente, glabro internamente; lobos 1,8-2 × $0,8_{-}$ $1,2 \mathrm{~mm}$, ovados, papilosos externamente, barbados para o ápice internamente. Estames semiexsertos; filetes $0,2-0,3 \mathrm{~mm}$ compr.; anteras $1-1,3 \mathrm{~mm}$ compr., basifixas, esparso-pilosas na base. Ovário $0,7-1 \mathrm{~mm}$ compr.; estilete 1-1,2 mm compr.; estigma capitado. Bagas amarelas, 2-2,5 $\times 2-2,5 \mathrm{~cm}$; pericarpo suculento, liso. Semente 1(2), ca. $15 \times 10 \mathrm{~mm}$.

Ocorre na Bolívia, Brasil, Guatemala, Honduras, México, Nicarágua, Panamá, Peru, Venezuela. No Brasil, ocorre na Amazonas, Bahia, Goiás, Mato Grosso, Espírito Santo, Minas Gerais, Rio de Janeiro, São Paulo, Paraná e Santa Catarina (Krukoff \& Monachino 1942; Guimarães et al. 2017). E5, E6, H8 e K8: florestas ombrófilas denso-montanas e submontanas, matas ciliares ou de galeria, em ambientes úmidos, preservados ou antropizados, sombreados ou à meia sombra, em solos ricos em húmus. Encontrada com flores de janeiro a dezembro e com frutos em abril.

Material selecinado - Formosa do Rio Preto, $10^{\circ} 58^{\prime} 12^{\prime \prime} \mathrm{S}$, 445ㄱ'00"W, 21 fev. 2005 (est.), M.L. Guedes \& A.B. Xavier 11652 (ALCB); Jussari, 15¹1'29"S, 39²9'43"W, 9 jun. 1968 (est.), R.P. Belém 2713 (CEPEC); Lençóis, 12³9'00"S, 41¹9'12"W, 29 jan. 1997 (fl.), S. Atkins et al. 4665 (CEPEC, HUEFS); Macaúbas, $12^{\circ} 05^{\prime} 12^{\prime \prime S}, 42^{\circ} 47^{\prime} 22^{\prime \prime W}, 7$ jul. 2007 (est.), A.A. Conceição et al. 2478 (HUEFS); Maracás, 13²7'38"S, 40¹9'25"W, 23 abr. 2002 (fr.), R.P. Oliveira et al. 767 (HUEFS); Mucuri, $18^{\circ} 05^{\prime} 50^{\prime \prime S}$, 39³3'28"W, 16 jul. 1968 (est.), R.P. Belém 3874 (CEPEC); Ruy Barbosa, 12॰18'15"S, 40²9'15"W, 19 dez. 2004 (fl.), L.P. Queiroz et al. 9965 (HUEFS).

Strychnos nigricans é um arbusto escandente da seção Breviflorae, caracterizado pelas folhas papiráceas a cartáceas, inflorescências hemisféricas, com poucas flores, congestas, de odor forte, e frutos com pericarpo suculento e membranáceo. Assemelhase a $S$. mattogrossensis, da qual se diferencia pelas folhas com nervuras mais proeminentes (vs. planas e mais finas) e inflorescências geralmente com menos flores (9-17 vs. mais que 15), brácteas menores (até 4 $\mathrm{mm}$ vs. mais que $5 \mathrm{~mm}$ compr.) e sépalas maiores que $1 \mathrm{~mm}$ (vs. menores ou iguais a $0,8 \mathrm{~mm}$ compr.).

\subsection{Strychnos parvifolia A. DC. in A.P. de Candolle,} Prodr. 9: 16. 1845.

Figuras 24A-D, 25 e 32I.

Arvoreta a arbusto escandente, 2-4 m alt.; ramos castanho-acinzentados, cilíndricos, raramente pubescentes; lenticelas pontiformes; espinhos presentes. Folhas subsésseis ou pecíolo até $2 \mathrm{~mm}$ compr.; lâmina verde, mesmo quando seca, discolor, $2-5,5 \times 1,5-3 \mathrm{~cm}$, ovada a largo-elíptica, cuneada a arredondada na base, acuminada, arredondada a aguda no ápice, simples a ciliada nas margens, cartácea a coriácea, glabra a pubescente em ambas as faces, quintuplinérvea. Tirsos terminais, congestos, 15-30 flores; pedúnculo $0,5-1,3 \mathrm{~cm}$ compr., piloso; brácteas 2-3,5 mm compr., lanceoladas, acuminadas no ápice, ciliadas nas margens. Flores com pedicelo até $1,5 \mathrm{~mm}$ compr. Sépalas verdes, $1-1,2 \times 0,6-0,8 \mathrm{~mm}$, ovadas, cuneadas a agudas no ápice, ciliadas nas margens. Corola amarelo-parda, curto-infundibuliforme; tubo $0,8-1 \quad \mathrm{~mm}$ compr., minutamente papiloso externamente, glabro internamente; lobos 1,5-2 × 1,2$1,5 \mathrm{~mm}$, ovados a ovado-lanceolados, minutamente papilosos externamente, papilosos e barbados para o ápice internamente. Estames semiexsertos a exsertos; filetes $0,3-0,4 \mathrm{~mm}$ compr.; anteras $0,6-0,8 \mathrm{~mm}$ compr., basifixas, esparso-pilosas na base. Ovário ca. $0,8 \mathrm{~mm}$ compr.; estilete $0,8-1 \mathrm{~mm}$ compr.; estigma depresso-capitado. Bagas amarelas, 1,5-2 × 1,3-2 cm; pericarpo suculento, liso. Semente 1(2), 1-1,5 × 1-1,2 $\mathrm{cm}$.

Ocorre na Bolívia, Brasil e Paraguai. No Brasil, está amplamente distribuída nos estados do Acre, Pará, Tocantins, Bahia, Ceará, Maranhão, Paraíba, Pernambuco, Piauí, Rio Grande do Norte, Goiás, Mato Grosso do Sul, Mato Grosso, Espírito Santo, Minas Gerais, Rio de Janeiro e São Paulo (Krukoff \& Monachino 1942; Guimarães et al. 2017). E7, E8, F4, D7, E7, E8, F4, F5, F6, F7, G5, G7, H7 e H8: cerrados e caatingas, florestas ciliares ou de galeria e florestas estacionais, em solos arenosos, tanto em áreas preservadas como perturbadas por ação antrópica. Floresce em novembro e frutifica em março.

Material selecionado - Bom Jesus da Lapa, $13^{\circ} 15^{\prime} 18^{\prime \prime} \mathrm{S}$, 4325'51"W, 16 mar. 1995 (fr.), G. Hatschbach 61975 (CEPEC, MBM); Caetité, $14^{\circ} 49^{\prime} 59^{\prime \prime} \mathrm{S}, 42^{\circ} 12^{\prime} 00^{\prime \prime} \mathrm{W}, 24$ mar. 1984 (est.), L.C.O. Filho \& J.C.A. Lima 121 (ALCB, HUEFS, MBM, RB); Encruzilhada, $15^{\circ} 31^{\prime} 53^{\prime \prime S}, 40^{\circ} 54^{\prime} 33^{\prime \prime} \mathrm{W}, 23$ maio 1968 (est.), R.P. Belém 3607 (CEPEC); Iaçu, 1245'18"S, 3951'24"W, 23 fev. 1997 (est.), E. Melo et al. 2115 (HUEFS); Ibicoara, $13^{\circ} 31^{\prime} \mathrm{S}, 41^{\circ} 28^{\prime} \mathrm{W}$, 15 nov. 1988 (est.), R.M. Harley et al. 26450 (CEPEC, HUEFS); Itaberaba, $12^{\circ} 29^{\prime} 57^{\prime \prime S}, 40^{\circ} 49^{\prime} 19^{\prime \prime} \mathrm{W}, 18$ mar. 2006 (est.), E. Melo et al. 4300 (HUEFS); Itatim, 12 ${ }^{\circ} 43^{\prime} 12^{\prime \prime} \mathrm{S}, 39^{\circ} 42^{\prime} 00^{\prime \prime} \mathrm{W}, 30$ mar. 1996 (est.), E. Melo et al. 1525 (HUEFS); Jequié, 1353'26"S, 


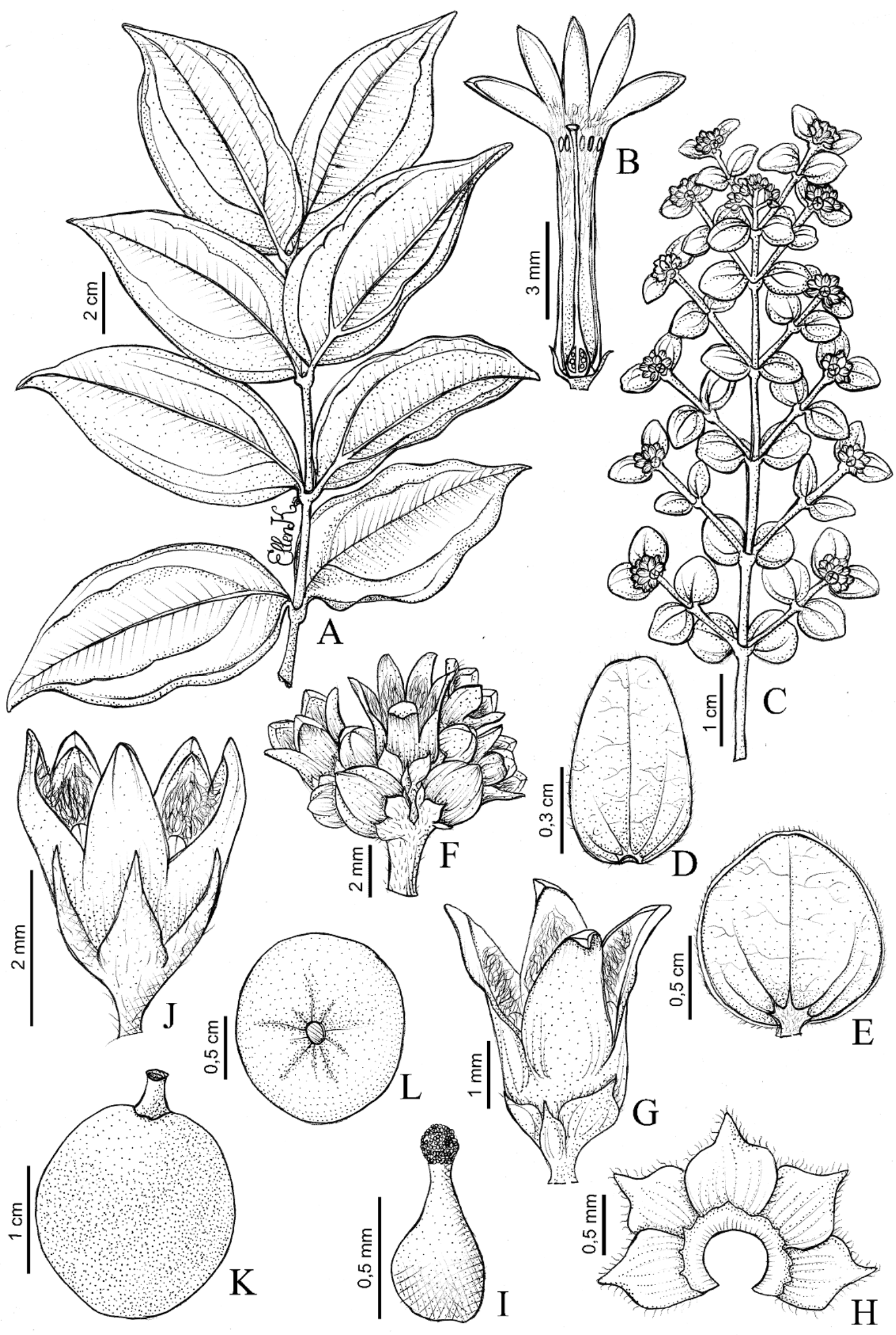

Figura 22. A-B. Strychnos mitscherlichii: A- ramo estéril; B- flor com parte do cálice removido e corola aberta. C-I. S. nana: C- ramo fértil; D- folha, face adaxial; E- folha, face abaxial; F- tirso; G- flor; H- cálice aberto, face abaxial; I- pistilo. J-L. S. nigricans: J- flor; Kbaga; L- semente, vista ventral. (A- Froés 19932; B- Ducke 22357; C-I- Fagg 1987; J- Atkins 4665; K, L- Oliveira 767). 
4007'19"W, 13 abr. 2007 (est.), L.P. Queiroz et al. 12953

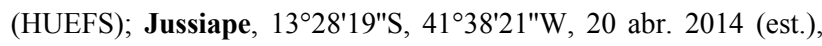
E. Melo et al. 12747 (HUEFS); Macaúbas, 1351'39"S, 42 $47^{\prime} 22^{\prime \prime W}, 7$ jul. 2007 (est.), A.A. Conceição et al. 2478 (HUEFS); Maracás, 1326'27"S, 40²5'50"W, 17 nov. 1978 (fl.), S.A. Mori et al. 11074 (CEPEC); Milagres, 1252'12"S, 3951'32"W, 13 out. 1981 (est.), A.M. Carvalho \& G.P. Lewis 960 (CEPEC, RB); Paramirim, 1325'59"S, 42²1'59"W, 28 nov. 1988 (est.), R.M. Harley \& N. Taylor 27024 (HUEFS, CEPEC, RB); Rio

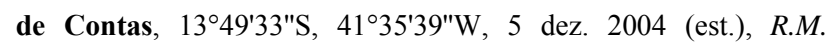

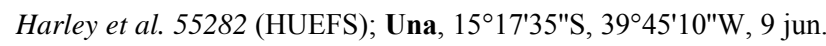
1968 (est.), R.P. Belém 3704 (CEPEC); Vitória da Conquista, 1451'57"S, 4050'21"W, 4 mar. 1978 (fr.), S.A. Mori et al. 9422 (CEPEC, RB).

Strychnos parvifolia é bastante polimórfica. Caracteriza-se pelo ápice pubérulo dos ramos, as folhas curto-pecioladas, ovadas a largo-elípticas, quintuplinérveas, sépalas ovado-agudas, ciliadas, corola com lobos ovados a ovado-lanceolados e barbados internamente mais para o ápice dos lobos. Assemelha-se a $S$. nana (ver comentário daquela espécie) e a $S$. rubiginosa, da qual se distingue pelos ramos e folhas pubescente a glabros (vs. velutinos).

3.14. Strychnos peckii B.L.Rob., Proc. Amer. Acad. Arts Sci. 49(8): 504. 1914 [1913].

Figura 24E-G, 25 e $32 \mathrm{~J}$.

Liana, ca. $10 \mathrm{~m}$ alt.; ramos castanhos a acinzentados, cilíndricos, glabros; lenticelas ausentes; gavinhas presentes. Folhas subsésseis ou pecíolo 6 $14 \mathrm{~mm}$ compr.; lâmina verde a verde-amarelada quando seca, discolor, 7-15 × 3-7,7 cm, oblonga a elíptica, cuneada a arredondada na base, acuminada a aguda no ápice, espessada e revoluta nas margens, subcoriácea a coriácea, glabra a glabrescente, triplinérvea, raro quintuplinérvea. Tirsos axilares, congestos, 12-25 flores; pedúnculo até $0,5 \mathrm{~cm}$ compr., densamente pubérulo a pubescente; brácteas 2,5-4 mm compr., ovadas, agudas no ápice, ciliadas nas margens. Flores sésseis ou pedicelo até $1,5 \mathrm{~mm}$ compr. Sépalas $0,5-0,8 \times 0,5-0,8 \mathrm{~mm}$, largo-ovadas, cuneadas a agudas no ápice, ciliadas nas margens. Corola amarela a creme, hipocrateriforme; tubo 8-9,5 mm compr., pubescente externamente, densamente piloso internamente; lobos 2-2,5 × 1,5-1,2 $\mathrm{mm}$, ovados, pubescentes externamente, pilosos a lanuginosos para a base internamente. Estames semiexsertos; filetes 0,4-0,5 mm compr.; anteras $1-$ 1,3 mm compr., dorsifixas, glabras. Ovário 1,5-2 mm compr.; estilete 10-12 mm compr.; estigma capitado. Bagas acinzentadas, 6,8-7 $\times$ 5,6-6,4; pericarpo lenhoso, levemente rugoso. Sementes 5-10, 2,2-2,5 $\times$ $1,5-2,2 \mathrm{~cm}$.

Ocorre na Bolívia, Brasil, Colômbia, Costa Rica, Equador, Guatemala, Guiana, Guiana Francesa, Honduras, México, Nicarágua, Panamá, Peru, Suriname e Venezuela. No Brasil, ocorre no Amazonas, Pará, Rondônia, Roraima, Bahia, Maranhão e Mato Grosso (Krukoff \& Monachino 1942;

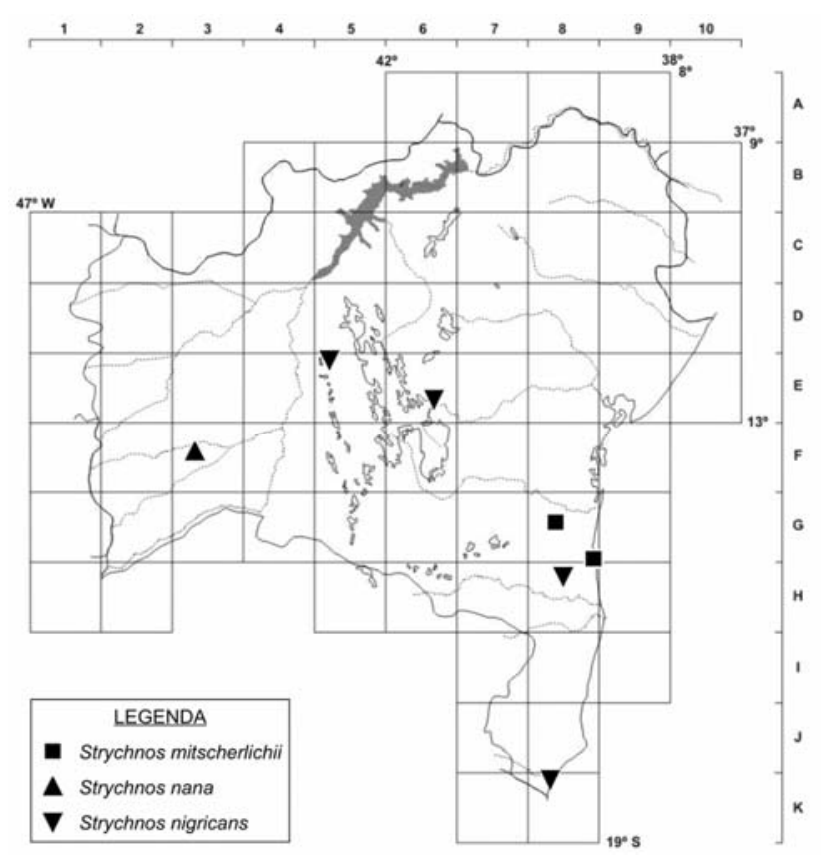

Figura 23. Mapa de distribuição de Strychnos mitscherlichii, S. nana e $S$. nigricans no estado da Bahia.

Guimarães et al. 2017). G8: florestas ombrófilas denso-montanas e submontanas, no interior da mata, em solos ricos em húmus.

Material examinado - Ilhéus, $14^{\circ} 47^{\prime} 20^{\prime \prime} \mathrm{S}, 39^{\circ} 29^{\prime} 38^{\prime \prime} \mathrm{W}, 17$ maio 1968 (est.), R.P. Belém 3576 (CEPEC); Maraú, 1406'11"S, 3908'49"W, 29 jun. 1968 (est.), R.P. Belém 3470 (CEPEC).

Material adicional - BRASIL. MATO GROSSO: Cuiabá, 26 set. 1963 (fl.), J.B. Maguire et al. 56851 (HUEFS). PARÁ: Bragança, 13 out. 1923, (fl.), A. Ducke s.n. (RB 18538); Faro, região dos Campos dos Tigres, 3 fev. 1910 (fr.), A. Ducke s.n. (RB 22336).

Strychnos peckii é uma liana de grande porte, com relatos de até $25 \mathrm{~m}$ de compr., alcançando o dossel das florestas, com flores amarelo-pardas. Quando estéril, pode ser equivocadamente identificada como S. romeubelenii (ver comentário daquela espécie) ou com S. erichsonii, diferindo desta última pelas folhas geralmente glabras a glabrescente (vs. glabras a pubescentes), opacas em ambas as faces (vs. lustrosa na face adaxial), além das inflorescências somente axilares (vs. terminais e axilares) e bagas sublenhosas, com pericarpo espesso (vs. fibrosas, com pericarpo fino).

3.15. Strychnos pseudoquina A.St.-Hil., Mém. Mus. Hist. Nat. 9: 340. 1822.

Figuras $24 \mathrm{H}-\mathrm{N}, 25$ e $32 \mathrm{~K}$.

Nome popular: pau-pra-tudo, quina e quina-docerrado.

Árvore 6-10 m alt.; ramos castanhos, cilíndricos, estriados, glabrescentes a vilosos quando jovens; lenticelas ausentes; espinhos e gavinhas ausentes. Folhas subsésseis ou pecíolo 2-10 mm compr.; lâmina verde a verde-amarelada quando seca, discolor, 5-10,5 $\times 2,5-6,4 \mathrm{~cm}$, elíptica a raro oblonga, cuneada na base, 


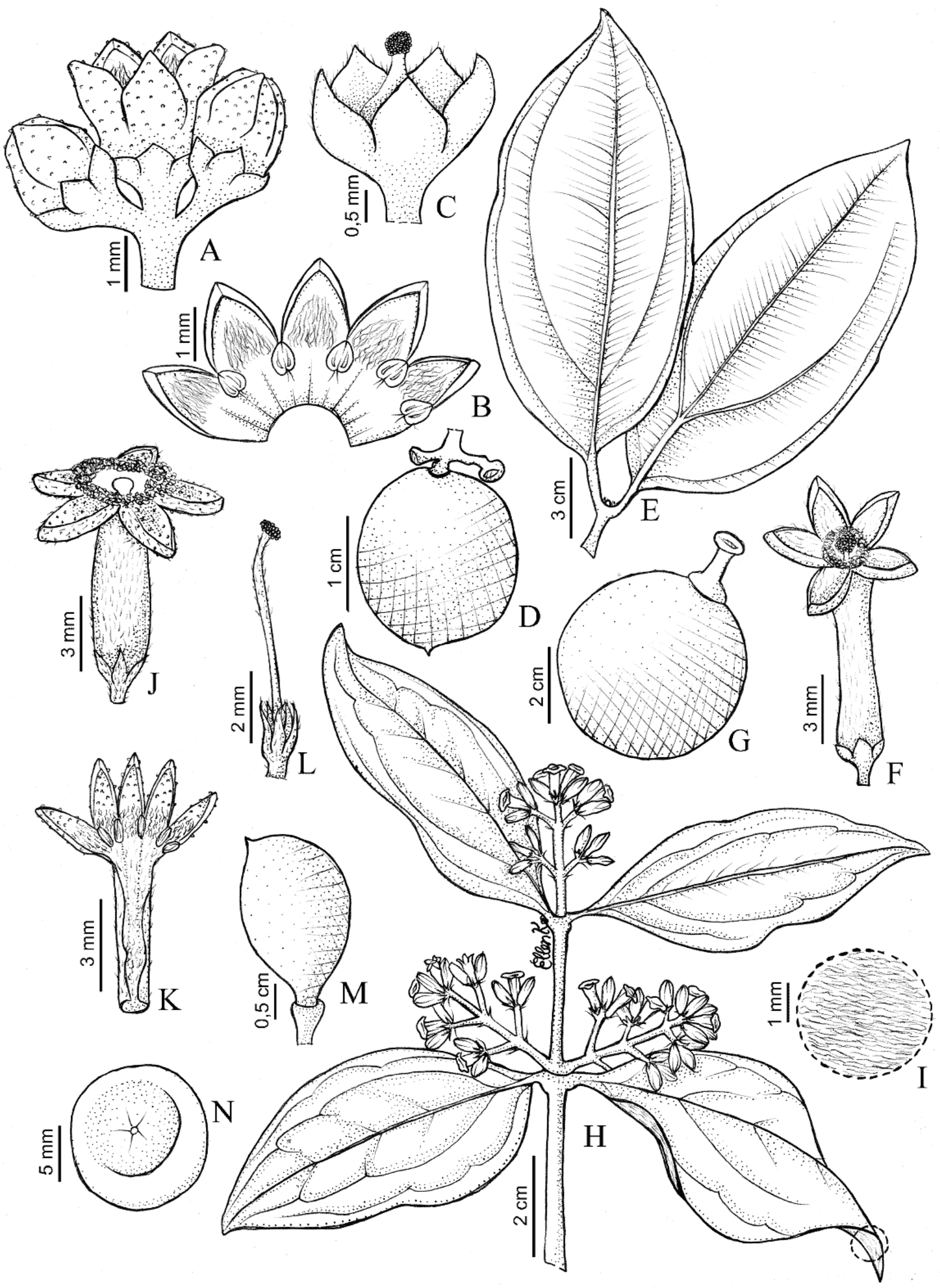

Figura 24. A-D. Strychnos parvifolia: A- dicásio, com flor e botões; B- corola aberta; C- cálice e pistilo; D- baga. E-G. S. peckii: E- ápice do ramo estéril; F- flor; G- baga; H-N. S. pseudoquina: H- ramo com inflorescências terminal e axilares; I- detalhe do indumento da face abaxial; J- flor; K- corola aberta; L- cálice e pistilo; M- baga; N- semente, vista ventral. (A-C- Harley 26450; D- Mori 9422; E- Belém 3576; F- Maguire 56851; G- Ducke 910; H-L- Guedes 13496; M, N- Hatschbach 30032). 


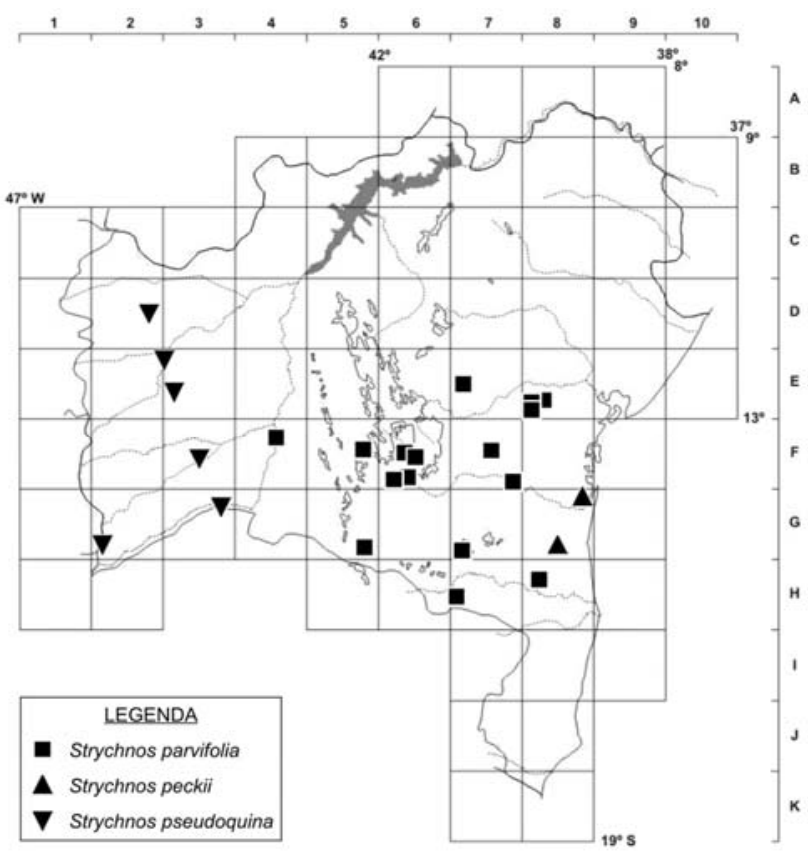

Figura 25. Mapa de distribuição de Strychnos parvifolia, S. peckii e S. pseudoquina no estado da Bahia.

arredonda a acuminada no ápice, espessada e ciliadas nas margens, coriácea, adaxialmente glabra, abaxialmente velutina, quintuplinérvea. Tirsos terminais e axilares, laxos ou congestos, 30 ou mais flores; pedúnculo até $1 \mathrm{~cm}$ compr., densamente viloso; brácteas 1,5-4 $\mathrm{mm}$ compr., lanceoladas, agudas a acuminadas no ápice, ciliadas nas margens. Flores sésseis ou pedicelo até $0,5 \mathrm{~mm}$ compr. Sépalas $1,2-1,5$ $\times$ ca. $0,5 \mathrm{~mm}$, lanceoladas, agudas a acuminadas no ápice, ciliadas nas margens. Corola amarelo-parda a creme, hipocrateriforme; tubo 7-8 mm compr., $\mathrm{d}-$ ensamente pubescente externamente, piloso internamente; lobos 2,5-3 × 1,2-1,8 mm, lanceolados a ovado-lanceolados, pubescentes para 0 ápice externamente, papilosos e densamente pilosos na base internamente. Estames semiexsertos, sésseis; anteras 0,8-1 mm compr., dorsifixas, glabras. Ovário 0,5-1 mm compr.; estilete 6-7 mm compr.; estigma capitado, adpresso. Bagas amarelas a amarelo-alaranjadas, 2-2,5 $\times$ 1,4-1,6 cm; pericarpo subcoriáceo, liso. Semente 1, $12-15 \times 11-14 \mathrm{~mm}$.

Ocorre na Bolívia, Brasil e Paraguai. No Brasil, ocorre em Tocantins, Bahia, Maranhão, Pernambuco, Goiás, Mato Grosso do Sul, Mato Grosso, Minas Gerais, São Paulo (Krukoff \& Monachino 1942; Guimarães et al. 2017). D2, E3, F3, G2 e G3: campos rupestres e, principalmente, cerrados, crescendo exposta ao sol, tanto em áreas preservadas quanto perturbadas, sobre solos litólicos. Floresce em abril e frutifica em maio e julho.

Material examinado - Barreiras, $12^{\circ} 09^{\prime} \mathrm{S}, 44^{\circ} 58^{\prime} \mathrm{W}, 27$ set. 2006 (est.), T.F. Nogueira 35 (ALCB); Cocos, 14²46'36"S, 4556'44"W, 15 maio 2001 (fr.), R.C. Mendonça 4273 (RB); Correntina, 133' $24^{\prime \prime S}, 44^{\circ} 30^{\prime} 15^{\prime \prime} \mathrm{W}, 29$ jul. 1989 (fr.), B.M.T. Walter et al. 277 (UEC); Feira da Mata, $14^{\circ} 14^{\prime} \mathrm{S}, 44^{\circ} 11^{\prime} \mathrm{W}, 20$ jul. 2007 (est.), M.L. Guedes \& R.M. Valadão 13655 (HUEFS);
Formosa do Rio Preto, $11^{\circ} 28^{\prime} 58^{\prime \prime} \mathrm{S}, 45^{\circ} 11^{\prime} 35^{\prime \prime} \mathrm{W}, 9$ abr. 1989 (fl.), R.C. Mendonça et al. 1448 (UEC); São Desidério, 12³6'S, $44^{\circ} 51^{\prime} \mathrm{W}, 1$ jul. 2001 (est.), D.L. Santana et al. 447 (ALCB, CEPEC).

Material adicional - BRASIL. DISTRITO FEDERAL: Brasília, Bacia do Rio São Francisco, 19 jan. 1981, (fl.), E.P. Henrique et al. 5989 (HUEFS). GOIÁS: Caiapônia, 21 jun. 1966, (fl.), D.R. Hunt \& J.F. Ramos 6110 (HUEFS); São João da Aliança, 9 fev. 1994, (fr.), G. Hatschbach \& J.M. Silva 60257 (HUEFS). MATO GROSSO: Chapada dos Guimarães, 25 abr. 2000, (f1.), L.A. Neto et al. 1061 (HUEFS).

Strychnos pseudoquina é uma espécie bastante peculiar da seção Longiflorae (veja comentário da sessão em S. bahiensis). Trata-se de uma arvoreta ou árvore com ramos estriados, sem gavinhas ou espinhos, com folhas glabras na face adaxial e velutinas na abaxial, nervuras planas na face adaxial, estilete piloso e bagas amarelo-alaranjadas, geralmente aristadas no ápice. Segundo Almeida et al. (1998), é uma espécie bastante utilizada na medicina popular, como afrodisíaco, tônico, no tratamento da malária ou contra problemas hepáticos, estomacais e anemia.

\subsection{Strychnos recognita Krukoff \& Barneby, Phytologia 27(2): 103. 1973.}

Figuras 26A-D e 27.

Trepadeira ca. $2 \mathrm{~m}$ alt.; ramos castanhos, cilíndricos, glabros, hirsutulosos a esparsotomentulosos; lenticelas ausentes; gavinhas presentes. Folhas subsésseis ou pecíolo 3-6 mm compr.; lâmina verde, castanha a negrejante quando seca, discolor, 2$17 \times 1,5-6,4 \mathrm{~cm}$, oblonga a elíptica, raramente ovada, arredondada a cuneada na base, arredondada a acuminada no ápice, revoluta nas margens, subcoriácea a coriácea, glabra a glabrescente na face adaxial, hirsutulosa a tomentulosa na abaxial, quintuplinérvea. Tirsos terminais, congestos, 18-25 flores; pedúnculo 2-3,5 cm compr., hirsutuloso; brácteas 0,5-4 $\mathrm{mm}$ compr., lanceoladas, agudas no ápice, ciliadas nas margens. Flores sésseis. Sépalas 1,3-1,5 × 0,6-0,8 mm, ovadas, agudas a acuminadas no ápice, ciliadas nas margens. Corola amarela, curtoinfundibuliforme; tubo 0,8-1 $\mathrm{mm}$ compr., minutamente papiloso a hispiduloso, glabro internamente; lobos ovados 1,6-1,8 × 0,8-1 mm, minutamente papilosos a esparso-hispidulosos, barbados para o ápice internamente. Estames semiexsertos; filetes ca. 0,2 mm compr.; anteras 0,6$0,8 \mathrm{~mm}$ compr., basifixas, pilosas na base. Ovário 0,6-0,8 mm compr.; estilete ca. $1 \mathrm{~mm}$ compr.; estigma capitado. Bagas imaturas amarelas, 1,5-3,5 $\times$ 1,1-3,5 cm; pericarpo subcoriáceo, levemente rugoso a liso. Sementes 1 ou 2, 1,1-1,7 × 1-1,2 cm.

Endêmica do Brasil, ocorrendo nos estados da Bahia e Espírito Santo (Krukoff \& Barneby 1973; Guimarães et al. 2017). G8 e I8: florestas ombrófilas denso-montanas e submontanas, em áreas preservadas. Floresce em setembro e frutifica em abril e outubro. 
Material selecionado - Guaratinga, $16^{\circ} 35^{\prime} 20^{\prime \prime} \mathrm{S}, 39^{\circ} 46^{\prime} 58^{\prime \prime} \mathrm{W}$, 13 set. 1968 (fl.), J.A. Jesus \& T.S. Santos 19 (CEPEC, MBM); Itacaré, $14^{\circ} 16^{\prime} 39^{\prime \prime} \mathrm{S}, 38^{\circ} 59^{\prime} 48^{\prime \prime} \mathrm{W}, 16$ abr. 1970 (fr.), T.S. Santos 727 (CEPEC); Uruçuca, $14^{\circ} 28^{\prime} \mathrm{S}, 39^{\circ} 06^{\prime} \mathrm{W}, 23$ out. 2003 (fr.), $P$. Fiaschi et al. 1720 (CEPEC).

Strychnos recognita pertence à seção Breviflorae. Quando vegetativa, assemelha-se a $S$. atlantica, especialmente por também apresentar folhas com nervuras bastante proeminentes na face abaxial. Pode ser diferenciada daquela espécie, no entanto, pelas folhas hirsutulosas a tomentulosas na face abaxial (vs. glabras em ambas as faces) e inflorescências com pedúnculo de 2-3,5 cm compr. (vs. até 0,7 mm compr.).

\subsection{Strychnos romeubelenii Krukoff \& Barneby,} Mem. New York Bot. Gard. 20(1): 22. 1969. Figuras 26E-J e 27.

Liana, até $30 \mathrm{~m}$ alt.; ramos castanhos, acinzentados ou negrejantes, cilíndricos, glabros, pubérulos a pilosos; lenticelas ausentes; gavinhas presentes. Folhas com pecíolo 3-10 mm compr.; lâmina verde, castanha a verde-amarelada quando seca, discolor, 5,5-16,5 $\times$ 2-7 cm, elíptica, oblonga a ovado-elíptica, cuneada, atenuada a arredondada na base, acuminada a cuneada no ápice, revoluta ou não nas margens, papirácea a coriácea, glabra em ambas as faces, triplinérvea a quintuplinérvea. Tirsos terminais e raramente axilares, laxos ou congestos, 40-50 flores; pedúnculo 0,3-2 cm compr., glabro a pubescente; brácteas 0,4-5 $\mathrm{mm}$ compr., ovadas, agudas no ápice, ciliadas nas margens. Flores sésseis ou pedicelo até $3 \mathrm{~mm}$ compr. Sépalas 0,8-1,2 × 0,4-0,6 mm, ovadas, agudas no ápice, ciliadas nas margens. Corola creme com lobos amarelos, hipocrateriforme; tubo 5-5,5 mm compr., papiloso externamente, piloso internamente; lobos 2 2,6 $\times$ 0,8-1,2 mm, ovado-lanceolados, papilosos externamente, pilosos para a base internamente. Estames semiexsertos; filetes ca. 0,2 mm compr.; anteras ca. 0,8 mm compr., basifixas, glabras. Ovário ca. $1 \mathrm{~mm}$ compr.; estilete 5,5-7 $\mathrm{mm}$ compr.; estigma depresso-capitado. Bagas imaturas verdes, 3,5-4,2 $\times$ 3,3-3,7 cm; pericarpo coriáceo, levemente rugoso a liso. Sementes 6-8, 1-1,2 × 0,8-1 cm.

Endêmica do Brasil, ocorrendo nos estados da Bahia e Espírito Santo (Krukoff \& Barneby 1969; Guimarães et al. 2017). F7, G8 e H8: florestas ombrófilas denso-montanas e submontanas. Floresce em julho, tendo sido coletada com frutos em fevereiro.

Material examinado - Itacaré, $14^{\circ} 16^{\prime} 39^{\prime \prime} \mathrm{S}, 38^{\circ} 59^{\prime} 48^{\prime \prime} \mathrm{W}, 5$ jul. 1968 (fl.), R.P. Belém 3504 (CEPEC); Itiruçu, 13³1'54"S, $40^{\circ} 09^{\prime} 01^{\prime \prime W}, 13$ fev. 1974 (fr.), T.S. Santos et al. 3444 (CEPEC); Una, $15^{\circ} 17^{\prime} 35^{\prime \prime S}, 39^{\circ} 45^{\prime} 10^{\prime \prime} \mathrm{W}, 9$ jun. 1968 (est.), R.P. Belém 3710 (CEPEC); Uruçuca, 14²5'23"S, 39³6'20"W, 24 abr. 1995 (est.), W.W. Thomas et al. 10914 (CEPEC).

Strychnos romeubelenii é uma trepadeira lenhosa que atinge até $30 \mathrm{~m}$ de altura, com folhas geralmente papiráceas a coriáceas, glabras em ambas as faces. É parecida com S. bahiensis, pelo formato e cor das folhas, distinguindo-se pelas nervuras secundárias, que emergem geralmente $0,7-1,5 \mathrm{~cm}$ acima da base da folha (vs. na base), as inflorescências terminais ou raramente axilares (vs. apenas axilares), sépalas menores (menos que $0,8 \mathrm{~mm}$ vs. mais que $1 \mathrm{~mm}$ compr.) e corola menor (menos que $8 \mathrm{~mm}$ vs. mais que $9 \mathrm{~mm}$ compr.), externamente papilosa (vs. pubescente).

\subsection{Strychnos rubiginosa A. DC. in A.P. de} Candolle, Prodr. 9: 16. 1845.

Figuras 27, 28A-F e 32L.

Arbusto 1-3,5 $\mathrm{m}$ alt.; ramos castanhoacinzentados, cilíndricos, escabros a velutinos; lenticelas ausentes; espinhos e gavinhas ausentes. Folhas subsésseis ou pecíolo até $2 \mathrm{~mm}$ compr.; lâmina verde a castanha, discolor, 2-8,5 × 1,5-5 cm, largoelíptica a largo-ovada, cuneada a arredondada na base, arredonda a cuneada no ápice, inteira nas margens, cartácea a papirácea, velutina em ambas as faces, indumento ferrugíneo, quintuplinérvea. Tirsos terminais, congestos, 30 ou mais flores; pedúnculo 2-3 cm compr., velutino; brácteas 0,5-7 $\mathrm{mm}$ compr., estreito-laceoladas, oblanceoladas a ovadas, agudas no ápice, ciliadas nas margens. Flores com pedicelos 1,5$3 \mathrm{~mm}$ compr. Sépalas verdes, 1-1,5 × 0,8-1 mm, ovadas, acuminadas no ápice, densamente ciliadas nas margens. Corola verde-clara, parda ou branca, curtoinfundibuliforme; tubo $1-1,2 \times 5-6 \mathrm{~mm}$, hirtelo externamente, glabro internamente; lobos 2-2,5 × 0,81,2 mm, ovados a ovado-lanceolados, papilosos e hirtelos externamente; papilosos e barbados para o ápice internamente. Estames semiexsertos; filetes 0,20,4 mm compr.; anteras 1-1,3 mm compr., basifixas, pilosas na base. Ovário 0,5-0,8 mm compr.; estilete $1-$ 1,2 mm compr.; estigma capitado. Bagas amarelas, ca. $2,6 \times 3 \mathrm{~cm}$; pericarpo subcoriáceo, liso. Semente 1(2), ca. $1 \times 0,8-0,9 \mathrm{~cm}$.

Ocorre na Bolívia e Brasil. No Brasil, está representada na Bahia, Ceará, Goiás, Mato Grosso, Mato Grosso do Sul, Minas Gerais, Paraíba, Paraná, Pernambuco, Piauí, Rio de Janeiro, São Paulo (Krukoff \& Monachino 1942; Guimarães et al. 2017). B/C5, B6, B9, D5, D6, E4, E6, F3 e G3: campos gerais, cerrados, caatingas, carrascos e campos rupestres, crescendo exposta ao sol, em áreas preservadas ou antropizadas, sobre solos pobres. Floresce praticamente o ano todo e frutifica em janeiro e maio.

Material selecionado - Casa Nova, $09^{\circ} 22^{\prime} 19^{\prime \prime} \mathrm{S}, 41^{\circ} 11^{\prime} 06^{\prime \prime} \mathrm{W}, 5$ jul. 2004 (est.), A.A. Conceição et al. 1164 (HUEFS); Coribe, $14^{\circ} 05^{\prime} 59^{\prime \prime S}, 44^{\circ} 43^{\prime} 55^{\prime \prime W}, 10$ abr. 2005 (est.), R.M. Castro et al. 1156 (HUEFS); Correntina, 13²0'35"S, 44³8'12"W, 21 jan. 1997 (fr.), G. Hatschbach et al. 66071 (HUEFS, MBM); Gentio do Ouro, $11^{\circ} 07^{\prime} \mathrm{S}, 42^{\circ} 43^{\prime} \mathrm{W}, 27$ fev. 1977 (fl.), R.M. Harley et al. 19142 (CEPEC); Glória, 09¹9'S, 38¹8'W, 9 mar. 2004 (est.), M.V. Moraes 627 (HUEFS); Ibotirama, 12 $11^{\prime} 07^{\prime \prime S}, 43^{\circ} 13^{\prime} 14^{\prime \prime} \mathrm{W}$, 11 out. 1981 (est.), G. Hatschbach 44149 (MBM, UEC); Lençóis, $12^{\circ} 20^{\prime} 24^{\prime \prime S}, 41^{\circ} 10^{\prime} 48^{\prime \prime W}, 3$ jun. 2001 (est.), D.M. Loureiro et al.

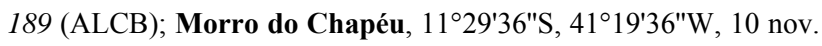
2007 (est.), F.B.L. Silva et al. 17 (HUEFS); Paulo Afonso, 09²19'S, $38^{\circ} 12^{\prime} \mathrm{W}, 3$ fev. 2006 (est.), M. Colaço 95 (HUEFS); Pilão Arcado, 


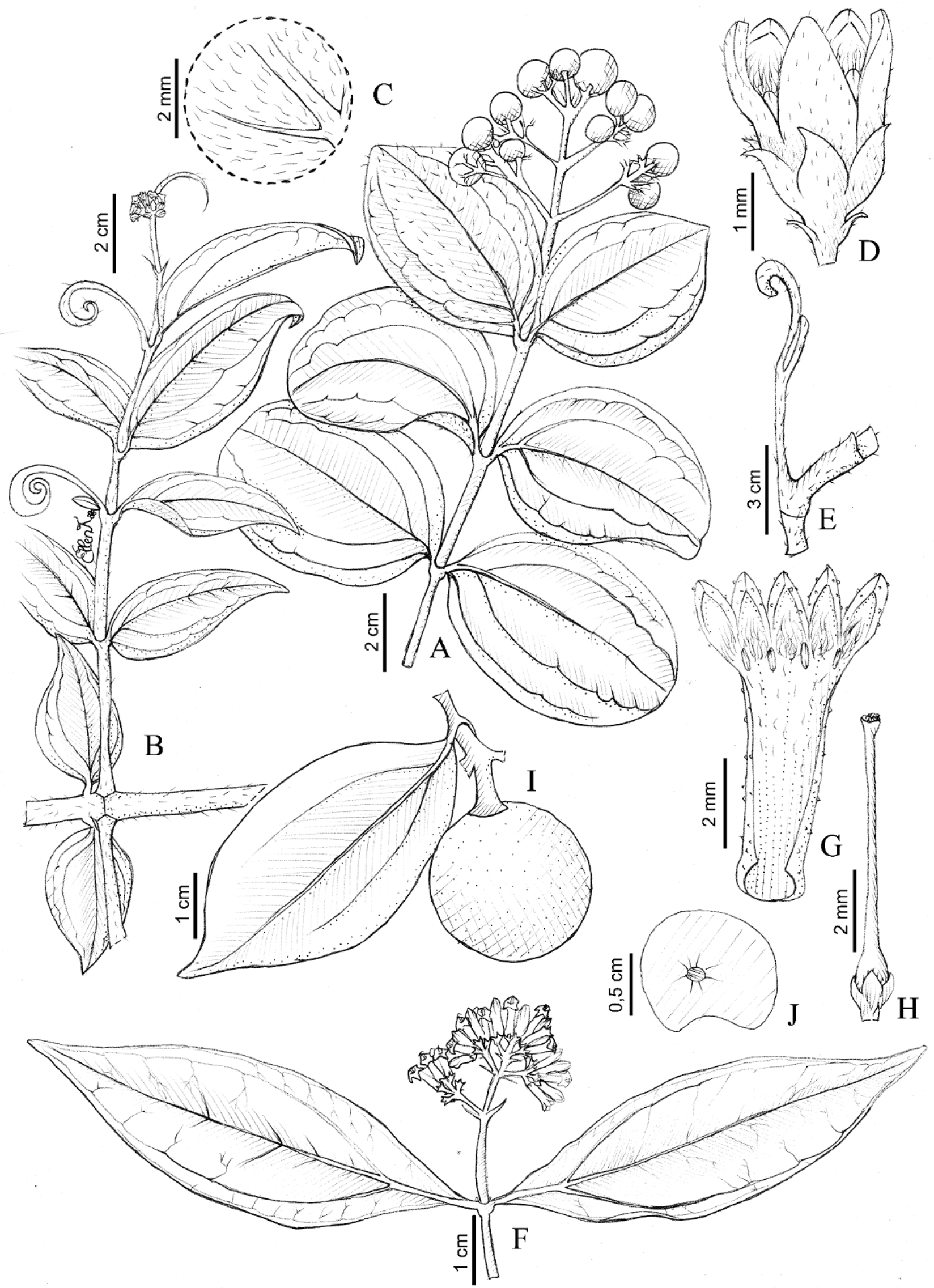

Figura 26. A-D. Strychnos recognita: A- ápice do ramo com infrutescência; B- ramo com inflorescência e gavinha; C- detalhe do indumento da face abaxial da folha; D- flor. E-J. S. romeubelenii: E- gavinha lenhosa no nó do ramo; F- ápice do ramo com inflorescência terminal; G- corola aberta; H- cálice e pistilo; I- ápice do ramo com folha e baga; J- semente, vista ventral. (A- Santos 727; B, D- Almeida 165; C- Santos 727; E-H- Belém 2980; I, J- Santos 3444). 


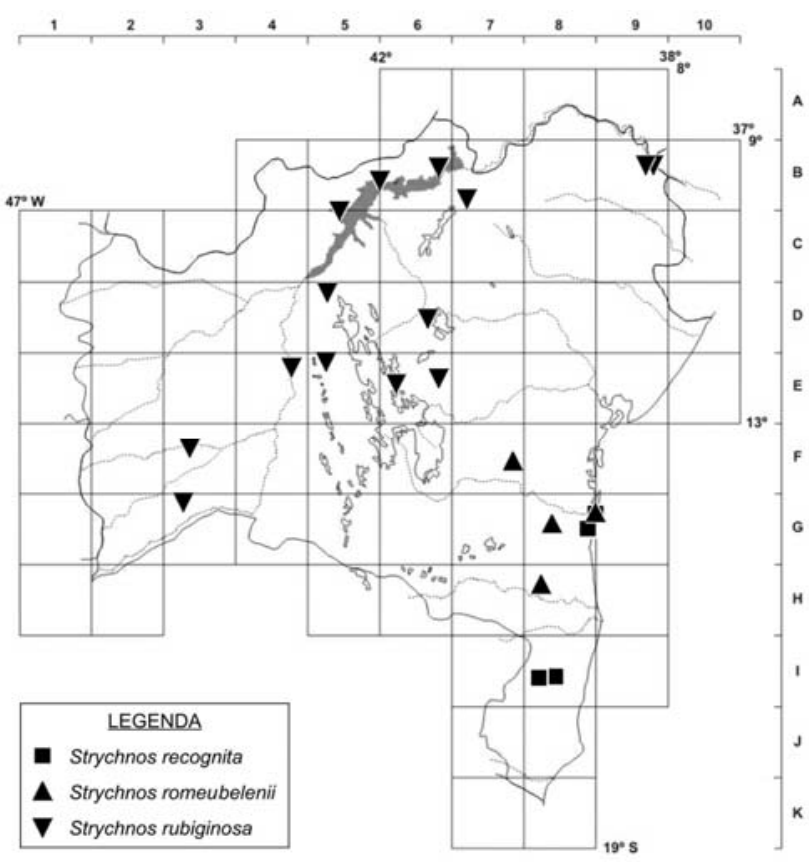

Figura 27. Mapa de distribuição de Strychnos recognita, S. romeubelenii e $S$. rubiginosa no estado da Bahia.

09 $59^{\prime} 12^{\prime \prime} \mathrm{S}, 42^{\circ} 33^{\prime} 47^{\prime \prime} \mathrm{W}, 6$ set. 2005 (est.), L.P. Queiroz et al. 10861 (HUEFS); Remanso, 09³2'48"S, 41 ${ }^{\circ} 59^{\prime} 34^{\prime \prime} \mathrm{W}, 1$ set. 2002 (est.), L.P. Queiroz et al. 7401 (HUEFS); Seabra, 12²5'06"S,

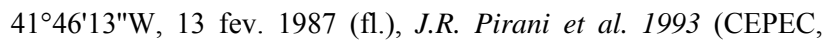
MBM); Sobradinho, $09^{\circ} 49^{\prime} 12^{\prime \prime S}, 40^{\circ} 47^{\prime} 43^{\prime \prime W}, 3$ out. 2003 (fl.), K.R.B. Leite et al. 375 (HUEFS); Xique-Xique, 1207'12"S, 4244'13"W, 16 maio 2009 (fr.), F. França et al. 5953 (HUEFS).

Strychnos rubiginosa pertence à seção Breviflorae e sua delimitação tem se mostrado complexa, como é comum nesta seção. Está amplamente distribuída em cerrados, campos rupestres e caatingas, apresentando pilosidade bastante densa, tricomas geralmente ferrugíneos quando secos. Assemelha-se a $S$. parvifolia, da qual se distingue principalmente pelo indumento densamente velutino (vs. glabra a pubescente).

\subsection{Strychnos setosa Krukoff \& Barneby,} Phytologia 41(4): 222. 1979.

Figuras 28G, 29 e 32M, N.

Trepadeira herbácea, ca. $2 \mathrm{~m}$ alt.; ramos castanhos a verde-amarelados, cilíndricos, pilosos; lenticelas ausentes; espinhos e gavinhas ausentes. Folhas subsésseis ou pecíolo 2-4 mm compr.; lâmina verde a verde-acinzentada quando seca, discolor, 4,5-15,5 $\times$ 1,7-4,8 cm, elíptica a ovado-elíptica, arredondada na base, aguda a acuminada no ápice, inteira nas margens, cartácea a membranácea, adaxialmente glabra, abaxialmente hirsuta, triplinérvea. Tirsos terminais, congestos, 21-25 flores; pedúnculo 1-1,5 cm compr., hirsuto; brácteas $2-4 \mathrm{~mm}$ compr., filiformes, agudas no ápice, com cílios hirsutos nas margens. Flores com pedicelos 0,5-2 mm compr. Sépalas verde-amareladas, 2,2-2,5 × 0,3-0,5 mm, lanceoladas, agudas no ápice, hirsuta nas margens. Corola creme, curto- infundibuliforme; tubo $0,6-1 \times 3-3,5 \mathrm{~mm}$, papiloso externamente, glabro internamente; lobos 2-2,2 × $0,5-$ $0,7 \mathrm{~mm}$, ovados a ovado-lanceolados, papilosos externamente, barbados para o ápice internamente. Estames semiexsertos; filetes 0,2-0,3 $\mathrm{mm}$ compr.; anteras $0,6-0,7 \mathrm{~mm}$ compr. Ovário 0,3-0,5 $\mathrm{mm}$ compr.; estilete $0,8-1 \mathrm{~mm}$ compr.; estigma capitado. Bagas não vistas. Sementes não vistas.

Endêmica da Bahia (Krukoff \& Barneby 1979; Guimarães et al. 2017). G8: florestas ombrófilas denso-montanas e submontanas, no interior da mata, em áreas sombreadas, com solos férteis, ricos em húmus. Foi coletada com flores em outubro.

Material examinado - Ipiaú, $14^{\circ} 08^{\prime} 13^{\prime \prime} \mathrm{S}, 39^{\circ} 44^{\prime} 20^{\prime \prime} \mathrm{W}, 30$ out. 1970 (fl.), T.S. Santos 1250 (tipo de Strychnos setosa: CEPEC).

Strychnos setosa é caracterizada pelos ramos e face abaxial das folhas completamente hirsutas, com tricomas de cerca de $1 \mathrm{~mm}$ de comprimento. É conhecida apenas pelo material-tipo, possui folhas pecioladas, elípticas, verde a verde-acinzentadas quando secas, triplinérveas, inflorescências terminais, com flores de sépalas lanceoladas de margens hirsutas e ápice bastante agudo, lobos da corola papilosos externamente e barbados internamente.

\subsection{Strychnos solimoesana Krukoff., Brittonia 4(2): 280. 1942.}

Figuras $28 \mathrm{H}$ e 29.

Trepadeira; ramos cinza a castanho-escuros, cilíndricos, lisos ou levemente rugosos, pubérulos; lenticelas ausentes; gavinhas presentes. Folhas subsésseis ou pecíolo 3-5 mm compr.; lâmina verdeclara, castanho-amarelada quando seca, opaca, discolor, 2-12,5 × 1,5-5,8 cm, oblonga a elíptica, cuneada a arredondada na base, aguda no ápice, inteira nas margens, cartácea, glabra na face adaxial, velutina na face abaxial, suave ao toque, com tricomas concentrados na axila das nervuras principais, triplinérvea. Inflorescência não vista. Flores não vistas. Bagas amarelas, 1,5-2 × 1,5-1,8 cm; pericarpo subcoriáceo, liso. Sementes não vistas.

Ocorre na Bolívia, Brasil, Colômbia, Equador e Peru. No Brasil, ocorre nos estados do Amazonas, Bahia e Pará (Krukoff \& Monachino 1942; Guimarães et al. 2017). G8 e H8: florestas ombrófilas densomontanas e submontanas, sobre solos ricos em húmus.

Material examinado - Itacaré, $14^{\circ} 16^{\prime} 39^{\prime \prime} \mathrm{S}, 38^{\circ} 59^{\prime} 48^{\prime \prime} \mathrm{W}, 7$ maio 1968 (est.), R.P. Belém 3503 (CEPEC); Una, 15¹7'35"S, 3945'10"W, 9 jun. 1968 (est.), R.P. Belém 3703 (CEPEC).

Material adicional examinado - BRASIL. AMAZONAS. São Paulo de Olivença: borda do Rio Solimões, s.d. (est.), B.A. Krukoff 9066 (tipo de Strychnos solimoesana: NY [foto]) PARÁ: Alto Tapajós, ao logo do rio Cururu 16 fev. 1974, (fr.), W.R. Anderson 10987 (NY [foto]).

Segundo Krukoff \& Monachino (1942), a espécie pertence à sessão Longiflorae (veja comentário da sessão em S. bahiensis). Strychnos solimoesana é caracterizada pelas folhas com nervuras profundamente impressas. A espécie é bastante peculiar porque a 


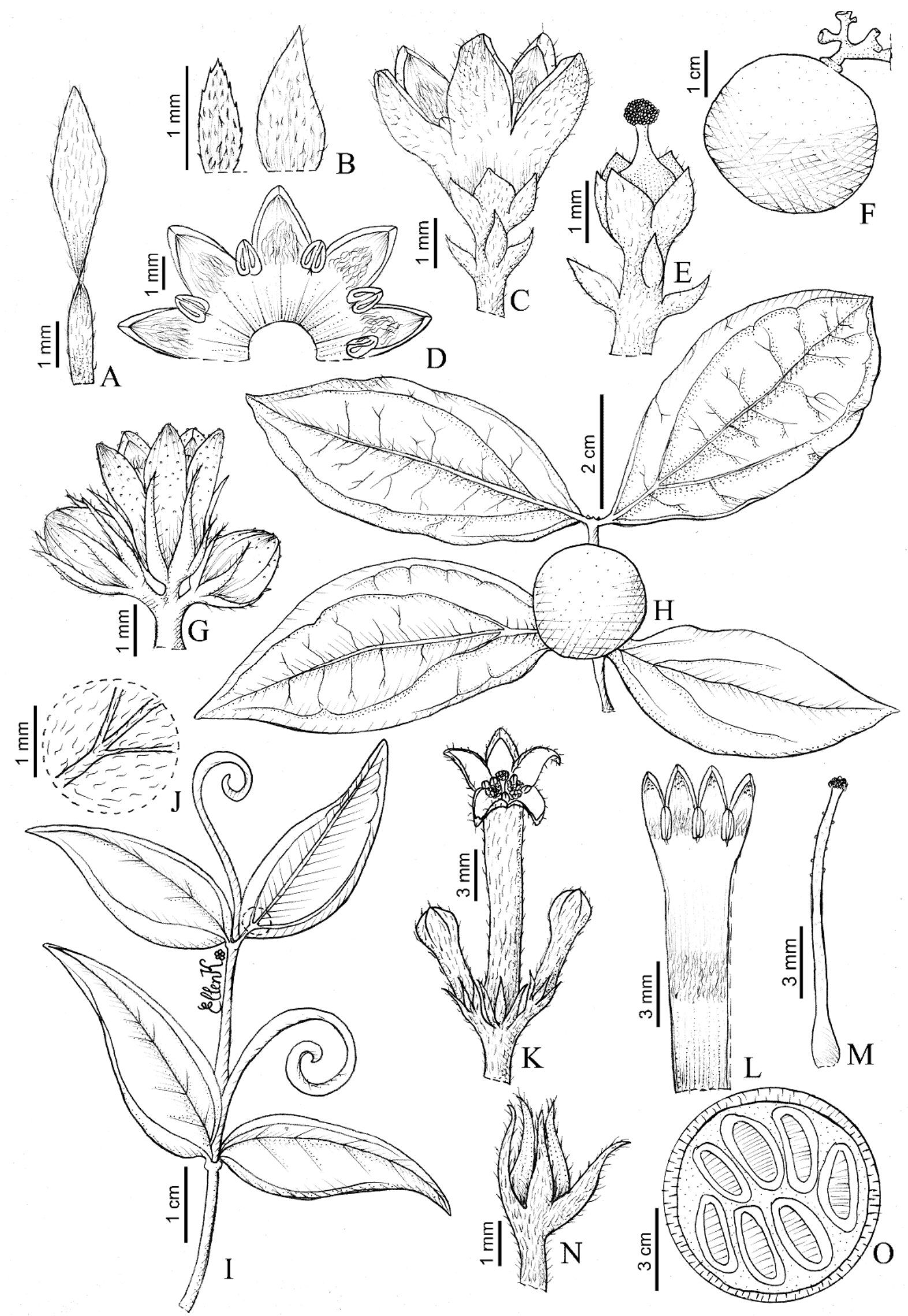

Figura 28. A-F. Strychnos rubiginosa: A- bráctea; B- brácteas, face adaxial, mostrando variação; C- flor, com brácteas; D- corola aberta. E- cálice e pistilo, subtendidos por brácteas; F- baga. G. S. setosa: dicásio, com flor e botões. H. S. solimoesana: ramo com baga axilar. I-O. S. trinervis: I- ápice do ramo com gavinhas; J- indumento da face abaxial da folha; K- dicásio, com flor e botões; L- corola aberta; M- pistilo; N- cálice; O- baga, corte transversal, mostrando o pericarpo e as sementes. (A-E- Queiroz 10861; F- França 4112; G- Santos 1250; H- Anderson 10987; I-N- Ganev 2154; O- Belém 3707). 
lâmina foliar, macroscopicamente, aparenta ser completamente glabra em ambas as faces, porém microscopicamente, apresenta indumento minutamente velutino, suave ao toque, na face abaxial. Assemelha-se a $S$. mitscherlichii por apresentar o segundo par de nervuras surgindo geralmente $1 \mathrm{~cm}$ acima da base da lâmina foliar. Entretanto, S. solimoesana apresenta indumento minutamente velutino, suave ao toque, na face abaxial das folhas (vs. glabra). A espécie não é conhecida com flores e suas bagas são aqui descritas com base no material do Pará, único fértil dentre as amostras coletadas até então. Suas inflorescências parecem formar tirsos congestos, terminais e axilares; as bagas são globosas, com pericarpo fino e provavelmente apenas 1 ou 2 sementes.

\subsection{Strychnos trinervis (Vell.) Mart., Syst. Mat.} Med. Veg. Bras.: 121. 1843.

Figuras 28I-O, 29 e $32 \mathrm{O}$.

Nome popular: quina-cruzeiro

Trepadeira a liana, até $8 \mathrm{~m}$ alt.; ramos castanhoacinzentados a ferrugíneos, cilíndricos, pilosos a pubescentes; lenticelas ausentes; gavinhas presentes. Folhas subsésseis ou pecíolo 2-5 mm compr.; lâmina verde a castanho-amarelada quando seca, discolor, 2-10 $\times 2-4,7 \mathrm{~cm}$, ovada a elíptica, cuneada a arredondada na base, acuminada a aguda no ápice, inteira nas margens, subcoriácea a coriácea, adaxialmente esparso-híspida a hirsuta, mais densamente nas nervuras, abaxialmente velutina, mais densamente nas nervuras, triplinérvea. Tirsos terminais, laxos, 12-30 flores; pedúnculo até 0,8 cm compr., hirsuto; brácteas 1,5-4 mm compr., linearlanceoladas, agudas no ápice, ciliadas nas margens. Flores sésseis ou pedicelo até $0,3 \mathrm{~mm}$ compr. Sépalas 2,5-3 × 0,5-1,5 mm, lanceoladas, densamente estrigosas, agudas no ápice, ciliadas nas margens. Corola verde, ferrugínea externamente, com lobos amarelo-vináceos, hipocrateriforme; tubo 11-14 $\mathrm{mm}$ compr., estrigoso externamente, piloso na porção mediana internamente; lobos 2-2,5 × 1-1,3 mm, ovados, estrigosos externamente, papilosos e barbados para a base internamente. Estames semiexsertos; filetes 0,3-0,5 $\mathrm{mm}$ compr.; anteras 1-1,2 $\mathrm{mm}$ compr., dorsifixas, glabras. Ovário 1,7-2 mm compr.; estilete 10-14 mm compr.; estigma capitado, depresso. Bagas imaturas verdes, 8-9,2 × 7,6-9 cm; pericarpo sublenhoso, liso. Sementes 16-20, 2-3 × 1,6-2,4 cm.

Ocorre na Bolívia e no Brasil. No Brasil, está representada em Alagoas, Bahia, Paraíba, Pernambuco, Rio Grande do Norte, Espírito Santo, Minas Gerais, Rio de Janeiro, São Paulo, Paraná, Rio Grande do Sul e Santa Catarina (Krukoff \& Barneby 1969; Guimarães et al. 2017). D5, F5, F8, G8, H8 e J8: florestas ombrófilas denso-montanas e submontanas e restingas, em áreas sombreadas, no interior de matas preservadas ou em bordas de trilhas, sobre solos ricos em húmus. Foi encontrada com flores em agosto e com frutos em junho e outubro.
Material selecionado - Apuarema, 135 $51^{\prime} 23^{\prime \prime} \mathrm{S}, 39^{\circ} 44^{\prime} 38^{\prime \prime} \mathrm{W}$, 18 out. 1997 (est.), M.L. Guedes et al. 5387 (ALCB); Caravelas, $17^{\circ} 44^{\prime} 07^{\prime \prime S}, 39^{\circ} 45^{\prime} 15^{\prime \prime W}, 4$ fev. 2002 (est.), M.L. Guedes et al. 9748 (ALCB); Gentio do Ouro, 11 ${ }^{\circ} 25^{\prime} 44^{\prime \prime} \mathrm{S}, 42^{\circ} 30^{\prime} 10^{\prime \prime} \mathrm{W}, 13$ mar. 1998 (est.), G. Hatschbach et al. 67725 (MBM); Ilhéus, 1447'20"S, 39²9'38"W, 17 maio 1968 (est.), R.P. Belém 3573 (CEPEC); Potiraguá, 1545'39"S, 39³0'48"W, 12 out. 1999 (fr.), B.M. Silva et al. 33 (HUEFS); Rio de Contas, 1346'12"S, 4222'59"W, 28 ago 1998 (fl.), W. Ganev 2154 (HUEFS). Una, $15^{\circ} 17^{\prime} 36^{\prime \prime S}, 39^{\circ} 04^{\prime} 31^{\prime \prime W}, 10$ jun 1968 (fr.), R.P. Belém 3706 (CEPEC, NY [foto]).

Strychnos trinervis pertence à seção Longiflorae (veja comentário da sessão em S. bahiensis). Na Bahia, assemelha-se bastante a $S$. bahiensis quando estéril, distinguindo-se pelas folhas adaxialmente esparsohíspidas a hirsutas (vs. esparso-pubérulas a glabrescentes), sépalas densamente estrigosas (vs. glabras) e maiores (ca. 2,5 $\mathrm{mm}$ vs. 1,2-1,5 $\mathrm{mm}$ compr.), tubo da corola estrigoso externamente e piloso na porção mediana e na fauce internamente (vs. papiloso externamente e completamente pubescente internamente).

\section{AgRAdecimentos}

Esta flora é parte dos resultados do mestrado de EKSB, desenvolvida no PPGBot-UEFS, com bolsa do CNPq e com apoio dos projetos Flora da Bahia (no 483909/2012-2) e Universal (no. 485468/2013-1), ambos financiados pelo $\mathrm{CNPq}$; $\mathrm{AR}$ é pesquisador $\mathrm{Pq}-$ $1 \mathrm{D}$ do CNPq.

\section{REFERÊNCIAS}

Almeida, S.P.; Proença, C.E.B.; Sano, S.M. \& Ribeiro, J.F. 1998. Cerrado: espécies de vegetais úteis. EMBRAPA/CPAC, Planaltina.

Backlund, M.; Oxelman, B. \& Bremer, B. 2000. Phylogenetic relationships within the Gentianales based on ndhf and rbcl sequences, with particular reference to the Loganiaceae. American Journal of Botany 87(7): 1029-1043.

Brandão, E.K.S. \& Rapini, A. 2017. Novelties in Strychnos sect. Breviflorae (Loganiaceae). Phytotaxa 329(3): 262-268.

Chamisso, L.K.A. \& Schlechtendal, D.F.L. 1826. Spigelia. In: Linnaea: Ein Journal für die Botanik in ihrem ganzen Umfange 1: 200-207.

Ducke, A. 1965. O gênero Strychnos no Brasil. Boletim Técnico do Instituto Agronômico do Norte 30: 1-64.

Frasier, C.L. 2008. Evolution and systematics of the angiosperm order Gentianales with an in-depth focus on Loganiaceae and its species-rich and toxic genus Strychnos. Ph.D. Thesis, Rutgers University. Disponível em: http://mss3.libraries.rutgers.edu /dlr/TMP/rutgers-lib_24550-PDF-1.pdf. Acesso em: 20 Dez. 2016.

Gibbons, K.L.; Conn, B.J. \& Henwood, M.J. 2012. Phylogenetic relationships in Loganieae (Loganiaceae) inferred from nuclear ribosomal and chloroplast DNA sequence data. Australian Systematic Botany 25: 331-340. 


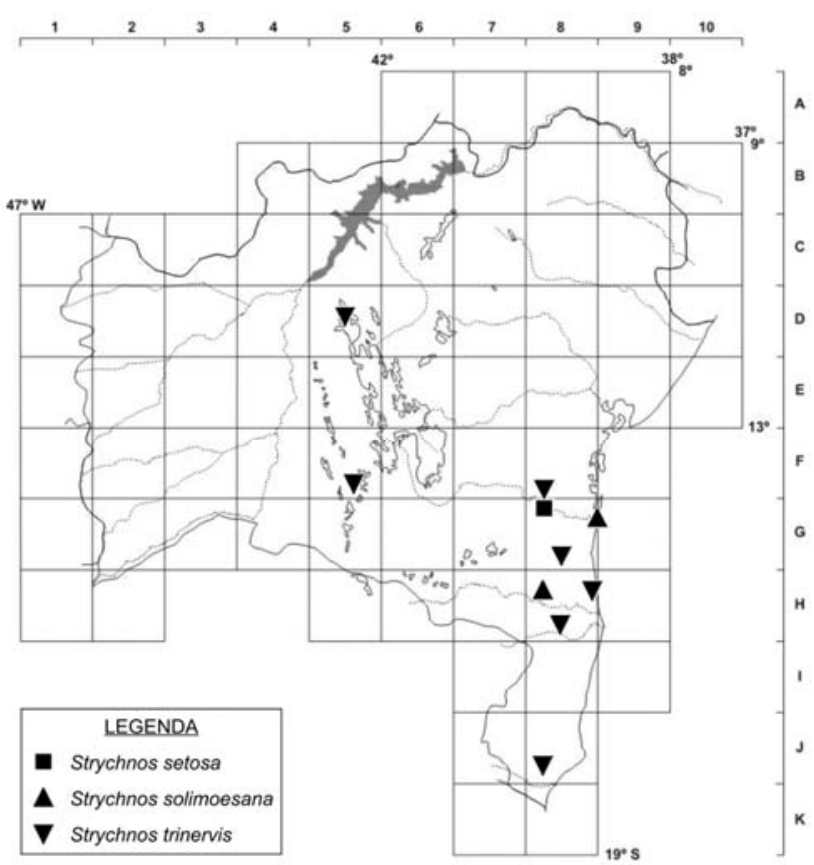

Figura 29. Mapa de distribuição de Strychnos setosa, S. solimoesana e S. trinervis no estado da Bahia.

Guimarães, E.F.; Manoel, E.A.; Siqueira, C.E. \& Zappi, D. 2017. Loganiaceae. In: Lista de Espécies da Flora do Brasil. Jardim Botânico do Rio de Janeiro. Disponível em http://floradobrasil.jbrj.gov.br/jabot/floradobrasil/FB151. Acesso em 10 mar. 2017.

Heywood, V.H. 1985. Las Plantas con Flores. Ed. Reverté, Barcelona.
Hoehne, F.C. 1939. Plantas e Substâncias Vegetais Tóxicas e Medicinais. Graphicars, São Paulo.

Krukoff, B.A. \& Barneby, R.C. 1969. Supplementary notes on the American species of Strychnos. VIII. Memoirs of the New York Botanical Garden 20(1): 1-93.

Krukoff, B.A. \& Barneby, R.C. 1973. Supplementary notes on the American species of Strychnos. XIII. Phytologia 27(2): 97-107.

Krukoff, B.A. \& Barneby, R.C. 1979. Supplementary notes on the American species of Strychnos. XVII. Phytologia 41: 222.

Krukoff, B.A. \& Monachino, J. 1942. The American species of Strychnos I. Brittonia 4: 248-322.

Pohl, J.B.E. 1831. Plantarum Brasiliae. Vol. 2A. Strauss, Wien.

Popovkin, A.V.; Mathews, K.G.; Santos, J.C.M.; Molina, M.C. \& Struwe, L. 2011. Spigelia genuflexa (Loganiaceae), a new geocarpic species from the Atlantic forest of northeastern Bahia, Brazil. PhytoKeys 6(6): 47-65.

Progel, A. 1868. Loganiaceae. In: C.E.P. Martius (ed.), Flora Brasiliensis. Vol. 6, pars 1. Frid. Fleischer, Leipsing, p. 251300.

Yang, L.-L.; Li, H.-L.; Wei, L.; Kuang, D.-Y.; Li, M.-H.; Liao, Y.-Y.; Chen, Z.-D.; Wu, H. \& Zhang, S.-Z. 2016. A supermatrix approach provides a comprehensive genus-level phylogeny for Gentianales. Journal of Systematics and Evolution 54: 400-415.

Zappi, D.C. 1989. Flora da Serra do Cipó, Minas Gerais: Loganiaceae. Boletim de Botânica da Universidade de São Paulo 11: 85-89.

Zappi, D.C. \& Lucas, E. 1998. Spigelia cremnophila Zappi \& E. Lucas (Loganiaceae) - a new species from the Chapada Diamantina, Bahia, Brazil. Kew Bulletin 53(4): 981-983.

\section{LISTA DE EXSICATAS}

Almeida, J. 19 (3.16), 128 (3.4), 352 (2.13); Almeida-Silva, G. 76, 163 (2.18); Alvarenga, D. 148 (3.15); Alves, L.J. 204 (1.1); Alves, M. 151 (1.1); Alves, R.J.V. 4055, 4195, 4213 (2.18), 4245 (2.5); Amorim, A.M. 843 (2.13), 996, 1002 (3.5), 1284 (2.13), 1445 (3.4), 1674 (2.13), 2148 (2.18), 2638 (3.4), 4032 (2.18), 4659 (2.1), 6261, 6660, 7307 (2.13), 7885, 7920 (3.3); Anderson, W.R. 10980 (3.20); Andrade-Lima, D. 74 (2.12); Aona, L.Y.S. 1257, 1525(2.1), 2241, 2047, 2857 (2.13), 2974 (2.8); Araújo, A.P.P. 86 (2.12); Arbo, M.M. 7415 (2.4), 7562 (2.18), 7779 (3.5); Atkins, S. 4665 (3.12); Bacelar, T.G. 34 (2.13), 58 (2.2); Barreto, V. 120 (2.12), 136 (2.11); Bastos, C. s.n. ALCB 64063 (2.18); Bautista, H.P. 1055 (3.21), 1338 (2.18), 1506 (3.5), 3011 (2.18), 3294 (1.1), 4333 (2.18), 4371 (2.7); Belém, R.P. 1813, 1815, 1818, 1825 (3.4), 2278 (3.3), 2713 (3.12), 2980 (3.17), 3110 (3.9), 3228 (3.3), 3460 (3.7), 3470 (3.14), 3472,3484 (3.4), 3497 (3.7), 3503 (3.20), 3504, 3506, 3509 (3.17), 3510 (3.4), 3512 (3.2), 3573 (3.21), 3576 (3.14), 3581 (3.4), 3607 (3.13), 3681 (3.4), 3703 (3.20), 3704 (3.13), 3706 (3.21), 3708 (3.2), 3710 (3.17), 3712 (3.3), 3714(3.4), 3722, 3723, 3324, 3326 (3.3), 3742 (3.4), 3788 (3.9), 3811 (3.1), 3874 (3.12), 3880 (3.1); Black, A.G. 48/3140 (3.7); Blanchet, J.S. 3392 (2.3); Borges, R.A.X. 680, 693 (2.13), 850 (2.8); Braga, J.M.A. 7255 (3.1); Brandão, E.K.S. 85 (3.18), 88 (2.18), 89 (3.21), 90 (3.8), 91 (2.13), 93 (3.8), 97 (2.8), 100 (2.1), 101 (2.2), 104 (1.1), 109 (2,18), 111, 112 (2.14), 121 (1,1), 124, 125 (2,5), 127 (2.2), 130, 131 (2.17), 136 (2.13); Brazão, J.E.M. 279 (3.5); Brito, H.S. 40 , 60 (2.8); Brito, J.C. 19, 76, 126 (2.18); Cardoso, D. 361 (3.5), 422 (2.5), 655 (2.14), 662 (2.12), 672 (2.11), 859 (3.18), 1412 (2.5), 1506 (2.13), 1652 (2.8), 2680 (2.13); Carneiro-Torres, D.S. 76, 155 (2.18), 648 (3.18); Carvalho, A.M. 960 (3.13), 971 (2.18), 1000 (2.5), 1104 (2.18), 1117 (2.5), 1322 (2.1), 1412 (2.13), 1507 (3.4), 1536 (3.13), 1640 (2.13), 1989 (3.13), 2162 (2.5), 2392, 2912 (2.18), 3033,3933 , 4001 (1.1), 4120 (3.16), 4185 (2.18), 4217 (2.8), 6337 (2.18), 6979 (3.8); Carvalho, P. 410 (2.11); Carvalho-Sobrinho, J.G. 31 (2.13), 307 (2.18), 653 (1.1), 656 (2.18), 710 (1.1), 2692 (2.1); Castellanos, A. 25885 (2.1); Castro, R.M. 996 (2.18), 1029 (1.1), 1083 (2.18), 1156 (3.18); Cerati, T.M. 265, 335 (2.18); Cerqueira, D.o. 9 (2.18); Chautems, A. 178 (2.18); Colaço, M. 95 (3.18); Conceição, A.A. 1164 (3.18), 1233 (2.13), 1358 (2.18), 1461, 1564 (3.18), 1660 (2.14), 1737 (2.6), 1841 (1.1), 2266 (2.17), 2478 (3.13), 2488 (1.1), 4104,4195 (2.6); Conceição, A.S. 616 (2.18); Conceição, S.F. 774 (2.18); Costa, A.L. s.n. ALCB 3256 (2.1), s.n. ALCB 3261 (2.18); Costa, G. 25,49 (2.18); Costa, J. 371 (2.7), 1765 (2.5); Costa, T.F. 25 (2.13); Couto, A.P.L. 137 (2.18), 172 (1.1); Damascena, L. 35, 42 (3.18); Daneu, L. 64 (2.13), 135 (3.4), 407 (2.13); Dardano, D. 48/3082; Dias, B.J. 48 (1.1); Duarte, A.P. 9333 (2.18), 10546 (3.5); Ducke, A. s.n. RB 18538 (3.14), s.n. RB 22336 (3.14), s.n. RB 22362 (3.6); Dunaiski Jr., A. 3745 (2.1); Eupunino, A. 193 (2.13); Fagg, C.W 3671 (3.11); Faria, E. de 13 (2.12); Farney, C. 3897 (2.7); Félix, L.P. 7514 (2.18), 7571 (2.11); Ferreira, J.L. 151 (2.18); Ferreira, M.C. 1117 (1.1), 1319 (2.7); 

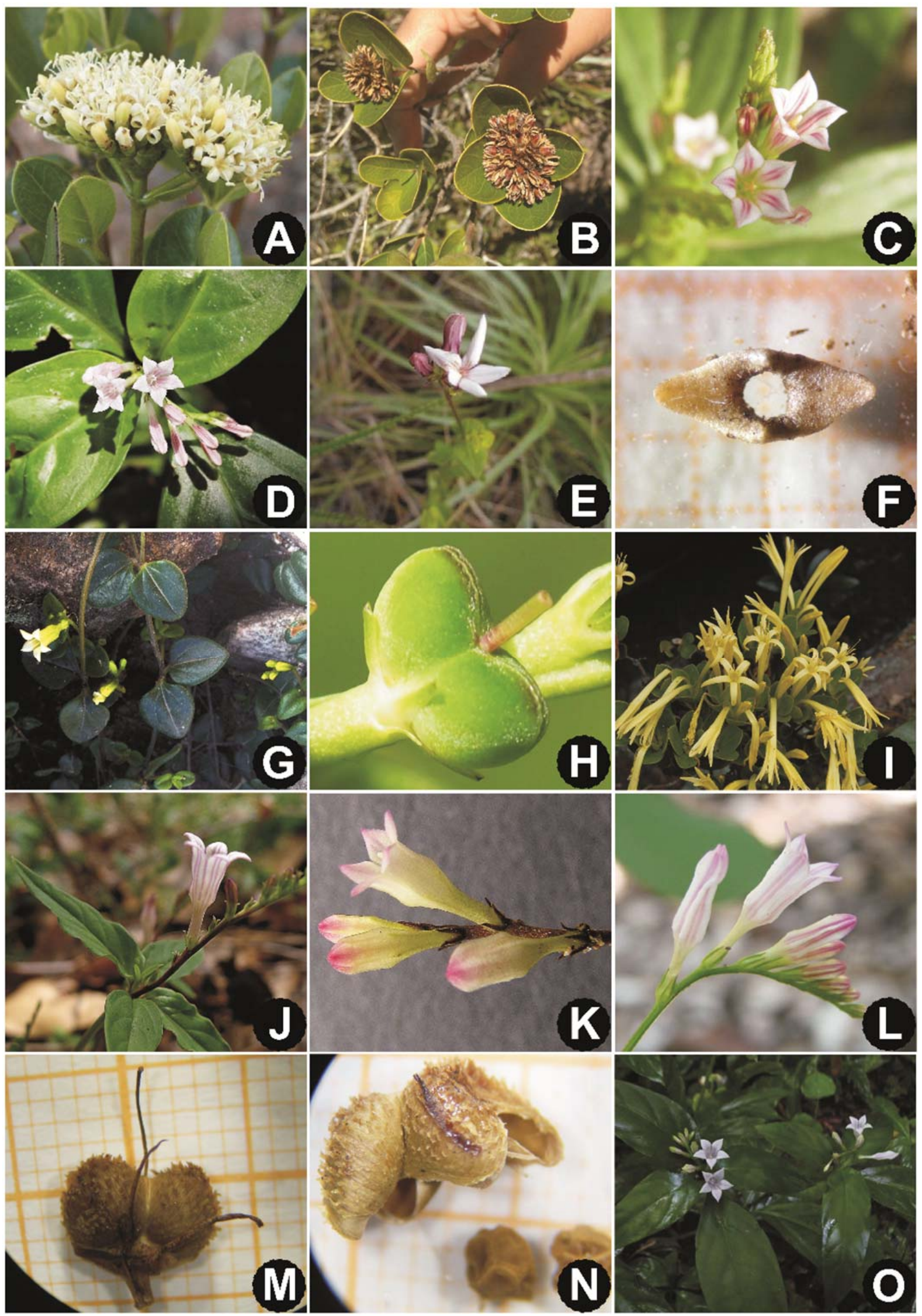

Figura 30. A, B. Antonia ovata: A- inflorescência; B- infrutescência. C. S. anthelmia: porção da inflorescência. D. S. beyrichiana: inflorescência. E. S. blanchetiana: inflorescência. F. S. brachystachya: carpoatlas (HUEFS 39066). G. S. cremnophila: inflorescência. H. S. elsieana: fruto. I. S. flava: inflorescência. J. S. flemmingiana: inflorescência. K. S. genuflexa: inflorescência. L. S. gracilis: inflorescência. M, N. S. kuhlmannii (HUEFS 98349): M- fruto; N- fruto expondo sementes. O. S. laurina: inflorescência. (Fotos: A-C, F-H, L-N- Ellen Brandão; D- Maurício Marcadante; E- Luciano Pedrosa; I- Jomar Jardim; J-K- Alex Popovkin; O- Idmá Gonçalves). 


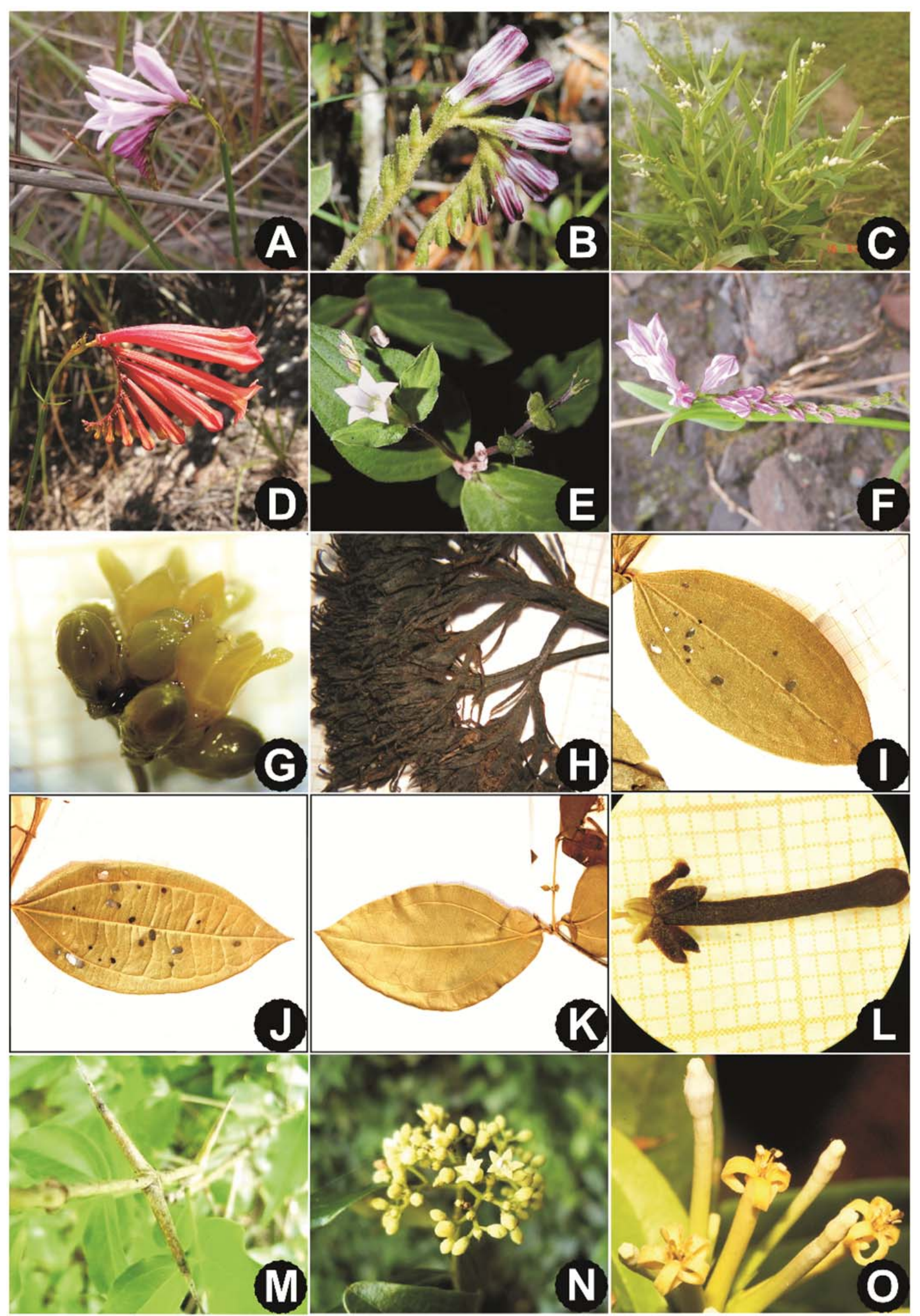

Figura 31. A. Spigelia linarioides: inflorescência. B. S. olfersiana: infrutescência. C. S. polystachya: inflorescência. D. S. pulchella: inflorescência. E. S. scabra: inflorescência. F. S. spartioides: inflorescência. G. Strychnos acuta: inflorescência (CEPEC6686). H. S. alvimiana: brácteas (CEPEC 94501). I, J. S. atlantica (CEPEC 12390): I- folha, face adaxial; J- folha, face abaxial. K, L. S. bahiensis (CEPEC 4026): K- folha, face abaxial; L- corola. M, N. S. brasiliensis: M- espinhos; N- inflorescência. O. S. divaricans: inflorescência. (A, B- Luciano Pedrosa; C-L- Ellen Brandão; M- Alex Popovkin; N- Maurício Verdi; O-Reinaldo Aguiar). 

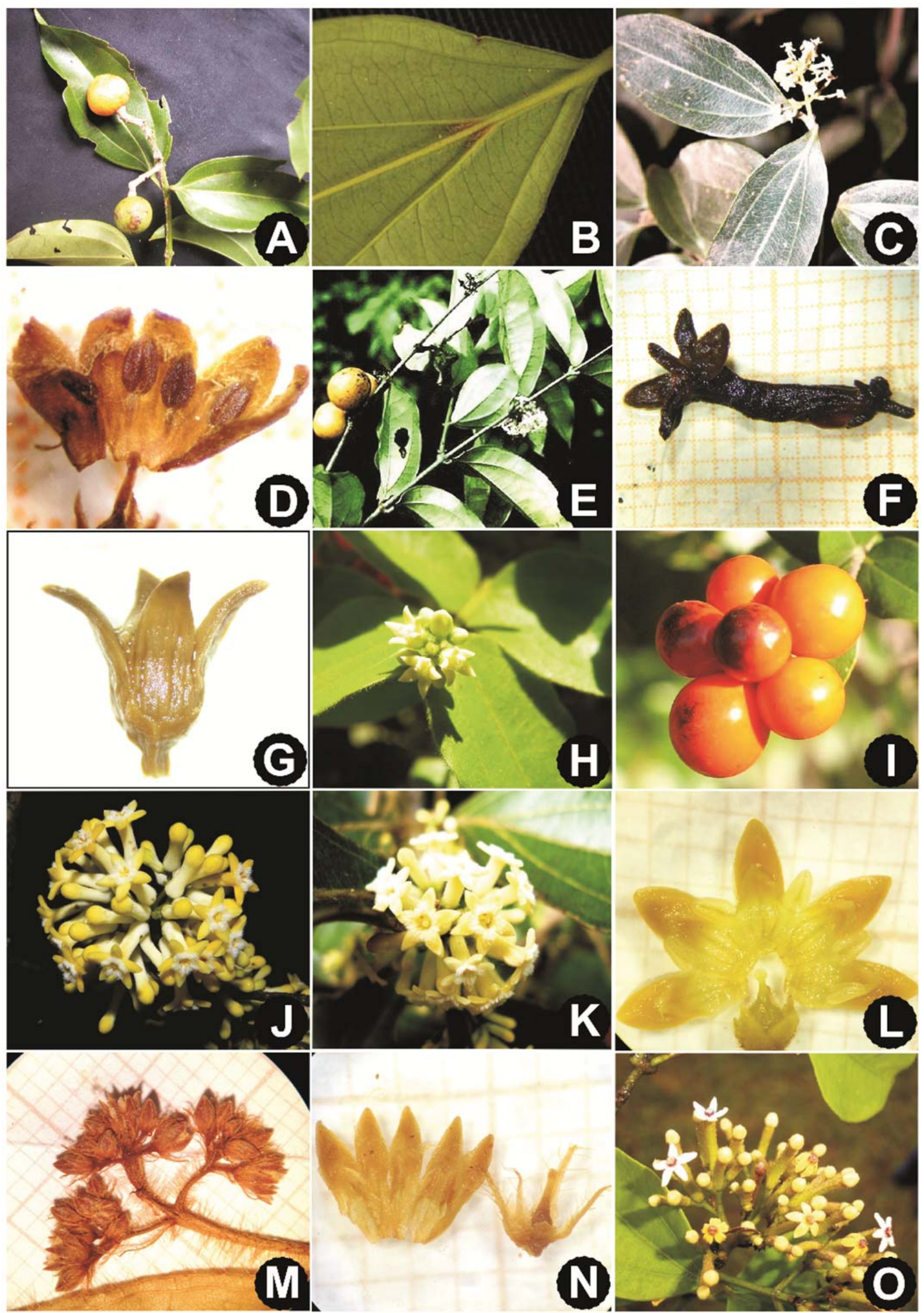

Figura 32. A. Strychnos erichsonii: infrutescência. B, C. S. gardneri: B- domácias nas axilas da folha; C- inflorescência. D. S. mattogrossensis: corola aberta (HUEFS 139708). E, F. S. mitscherlichii: E- inflorescência; F- flor (RB 226566). G. Strychnos nana: flor (HUEFS 215796). H. S. nigricans: inflorescência. I. S. parvifolia: infrutescência. J. S. peckii: inflorescência. K. S. pseudoquina: inflorescência. L. S. rubiginosa: flor aberta e pistilo (HUEFS 84130). M, N. S. setosa (CEPEC 6264): M- inflorescência; N- flor aberta e pistilo. O. S. trinervis: inflorescência. (A, J- Reinaldo Aguiar; B, D, F-H, L-N- Ellen Brandão; C- Daniela Zappi; I- Antônio Sérgio; K- Valdir Dala Mata; O- Greta Dettke). 
Fiaschi, P. 1720 (3.16), 1753 (2.13), 2222 (3.9), 2413 (2.18); Fonseca, M.L. 2862 (1.1); Fonseca, W.N. 278 (2.18), 388 (2.15); Forzza, R.C. 1168, 1315, 3873 (2.18); França, F. 1028 (2.18), 1424, 1520 (3.13), 2676 (2.18), 2952 (2.11), 3050 (2.18), 3399 (2.13), 4112 (3.18); Freitas, I.S. 15 (2.18); Freitas, J.G. 559 (3.11); Fróes, R.L. 12724 (3.10), 12732 (3.4), 12735/91 (3.2), 19930 ( 3.16 ) 19931 (3.14), 19932 (3.10), 20034 (3.16), 21527 (3.20); Funch, L.S. 40, 133, 181 (1.1), 1079 (2.18), 1611 (1.1); Funch, R. 14, 23 (2.18), 61 (1.1), 134 (2.18), 308, 374 (1.1), 451, 509, 521, 697, 747, 763 (2.18); Furlan, A. 339 (3.18), 388 (2.18), 7555 (2.14); Ganev, W. 203,234 (1.1), 249 (2.7), 890 (1.1), 1138 (2.6), 1411 (2.18), 2154 (3.21), 2321 (2.7), 2624 (2.18), 3100, 3157 (1.1), 3211 (2.18), 3280 (1.1), 23219 (2.7); Gasson, P. 2162 , 5909 (2.5); Gimenes, M. 7 (2.18); Ginzbarg, S. 872 (2.18); Giulietti, A.M. 1232 (2.18), 1539, 1569 (2.4), 1765 (2.17), 2254 (1.1), 2323 (2.11), 2535 (2.13); Glaudino, C. 776 (3.1); Gomes, F.S. 311 (3.8), 419 (1.1), 551 (2.18), 1259 (2.1); Gonçalves, L.M.C. 129 (3.18); Grupo Pedra do Cavalo 116 (2.1), 233, 915 (2.17); Guedes, M.L. 299, 403, 645, 738, 1079, 1398, 1437, 1499 (2.18), 1507 (1.1), 2073 (2.18), 3445 (2.1), 3449 (2.8), 4899 (2.18), 5171 (2.8), 5222 (2.18), 5486 (1.1), 6731 (3.4), 8239 (1.1), 9748 (3.21), 9937, 10728,11522 (2.18), 11934 (3.4), 12142 (2.18), 12169 (2.12), 12246 (1.1), 12454 (2.18), 12453 (1.1), 12562 (2.18), 12806 (1.1), 13496, 13655 (3.15), 13909 (1.1), 13914, 14184 (2.18), 14187 (2.13), 14298 (2.7), 14302 (1.1), 14551 (2.8), 14796 (1.1), 14825 (3.8), 14833 (2.18), 15056 (2.11), 16049 (3.8), 16761, 16916 (1.1), 17227 (2.17), 17718 (2.18), 18192 (2.1), 18838, 20141 (1.1), 20824 (2.18), 20841 (1.1), 21053 (2.13), 21722 (1.1), 21799,21820 (2.18), 23540 (3.8); Guimarães, E.F. 1023 (2.13), 1707, 1737 (2.18); Hage, J.L. 424 (2.13), 2005 (2.1); Harley, R.M. $15090,15159,15580,15999$ (2.18), 16533, 16543 (2.12), 16591 (2.13), 16728, 16786 (2.14), 16847 (2.14), 17241 (2.8), 17400 (2.13), 17454 (2.8), 17606, 17877, 18217, 18467 (2.13), 18679 (2.18), 19142 (3.18), 19720, 20637, 20798 (2.18), 21258 (1.1), 22095 (3.4), 22114 (2.13), 22302 (2.18), 22392 (2.13), 22476 (1.1), 22520, 22530 (2.5), 24418 (2.7), 25374, 25588 (2.18), 25809, 25976 (2.7), 26002 (2.18), 26019, 26310 (2.7), 26450 (3.13), 26477 (2.18), 27012 (1.1), 27024 (3.13), 27520 (2.7), 28268 (1.1), 28415 (2.13), 50148 (2.18), 50598 (2.6), 54351 (3.18), 54960 (2.7), 55059 (2.8), 55282 (3.13); Hatschbach, G. 44149, 44235 (3.18), 44434 (2.18), 45123 (3.13), 47480 (2.18), 48269, 48279 (2.9), 48284 (2.18), 48308 (1.1), 53385, 56961 (2.18), 56969 (2.1), 60257 (3.15), 61975 (3.13), 65982 (2.1), 66071 (3.18), 67725 (3.21), 67857 (2.18), 75188 (2.8), 75325 (2.13), 75468, 77596 (2.1); Henrique, E.P. 5989 (3.15); Hind, D.J.N. 3517 (2.5), 4276 , 4386 (2.7), 50911 (2.18); Hunt, D.R. 6110 (3.15); Hurbath, F. 23 (2.18); Ibrahim, M. 67 (2.18), 116 (2.13); Irwin, H.S. 30799,30863 (2.18); Jardim, J.G. 200 (3.4), 745 (2.18), 859 (3.9), 1822 (3.4), 1961, 1985 (2.2), 2728 (3.4), 2894 (3.9), 3081, 4088, 4286, 4457, 4821, 4990, 5011, 5093, 5218 (2.13); Jesus, J.A. 19 (3.16), 128 (3.4), 165 (3.16), 1304 (2.18); Kral, R. 72741, 75486, 75628 (2.18); Krieger, L. 9658 (2.16); Leite, K.R.B 398 (3.18); Lewis, G.P. 895 (2.5), 1954 (2.18), 7637, 36637 (2.12); Lima, H.C. 728 (2.18); Lima, J.C.A. 305 (1.1); Lôbo, C.M.B. 45 (2.5); Lopes, M.M.M. 399, 731, 1262 (2.13); Loureiro, D.M. 72 (2.18), 189 (3.18), 467 (2.18); Lughadha, E.N. 6158 (2.18); Machado, R.F. 114 (2.1); Maguire, J.B. 56851 (3.14); Marquete, R. 4441 (2.18); Martinelli, G. 5302 , 5472 (2.18), 6652 (3.13), 9638 (3.5); Martins, C.T.V.D. 282 (1.1), 283 (2.18); Martius, C.F.P. (2.16); Matos, A.O. 49, 56 (2.13); Matos, E.N. 690 (2.13), 3467 (2.8), 3531 (2.13); Matos, L.A. 1903 (3.4), 2304 (3.9); Mayo, S. 1204 (2.18); Melo, E. 983 (1.1), 1053 (2.8), 1135 (2.18), 1167,1195 (2.5), 1267 (2.4), 1277 (2.5), 1325 (2.18), 1442, 1525, 2115 (3.13), 2755 (2.1), 2854 (3.8), 3169 (3.18), 3330 (2.11), 4300, 4310, 6064 (3.13), 6333 (2.1), 6854 (3.5), 7150 (3.11), 8358 (2.18), 9052, 9053, 9135, 9668 (2.13), 10812 (3.1), 11439 (3.13), 11805, 12155 (2.17), 12747 (3.13), 12808 (1.1); Mello, L.E. 2952 (3.3); Mello-Silva, R. 2812 (2.14); Mendes, M.S. 452 (1.1); Mendonça, R.C. 1448, 4273 (3.15); Mileski, E. s.n. RB 226566 (3.10); Miranda, A.A.C. 9 (2.18); Miranda, A.M. 5802 (1.1); Miranda, C.A. s.n. RB 203087 (1.1); Miranda, E.B. 103 (2.4), 109 (2.14), 453 (1.1), 739 (3.15), 985 (2.19), 986 (2.18), 990 (2.7), 1000 (2.5), 1001 (2.1), 1062 (2.2); Monteiro, R.F. 637 (1.1); Moraes, A. 13 (2.18); Moraes, M. 504 (2.18); Moraes, M.V. 627 (3.18), 673 (2.20); Moraes, P.L.R. 2789 (2.18); Moreira, M.C. 1117 (1.1); Mori, S.A. 675 (3.9), 9284 (2.13), 9308 (2.8), 9422 (3.13), 9471 (2.8), 9924 (3.13), 11074 (3.13), 11129 (3.13), 11177 (3.6), 11654 ( 3.4), 11744 (3.16), 11795 (3.13), 11806 (3.13), 11964 (2.13), 12295 (1.1), 13227, 13288 (2.5), 13486 (3.9), 13498,14390 (2.18); Nascimento, A.F.S. 95 (2.1); Nascimento, J.G.A. 305 (2.18); Neto, L.A. 1061 (3.14); Neves, M.L.C. 26 (2.13); Neves, S.P.S. 218 (1.1); Noblick, L.R. 1047 (2.1), 1244, 1430 (2.18), 1764 (2.4), 1771 (2.18), 1940 (2.17), 2812 (2.5), 3213 (2.8), 3629 (3.13); Nonato, F.R. 831 (2.18); Nunes, T.S. 189, 249 (2.18), 512, 719 (3.18), 1185 (2.12), 1382 (2.13), 1445 (2.11), 1523, 50076 (2.18); Ogasawara, H.A. 63 (1.1); Oliveira-Filho, L.C. 121 (3.13); Oliveira, D. 7 (2.8); Oliveira, E.C. 99 (2.18); Oliveira, J.A. 233 (2.18); Oliveira, J.F.C. 12 (2.1); Oliveira, P.P. 7 (2.5); Oliveira, R.P. 114 (2.7), 151 (2.18), 478 (1.1), 767 (3.12), 1233, 1240 (2.13), 1919, 2055 (2.18); Orlandi, R.P. 289 (3.13), 336 (2.18), 504 (2.14), 506 (2.5), 528 (2.18), 534, 538 (3.18); Pacheco, L.M. 140 (2.1); Paixão, J.L. 297 (3.4), 1111, 1144 (2.13); Pastore, J.F.B. 2112 (2.8), 2202 (2.18), 2400 (2.20); Paula, J.E. 520 (1.1); Paula-Souza, J. 5073 (2.18),t 6101 (2.13), 6207 (2.5); Pedrosa, R. 2 (2.12); Pereira, E. 2187 (2.18), 2189 (1.1); Pereira-Silva, G. 8396 (2.18); Pigozzo, C.M. 27 (2.18); Pimenta, K.M. 394 (2.18); Pinheiro, R.S. 1555 (2.2), 2281 (3.3); Pinto, G.C.P. $33 / 80$ (3.21), $52 / 57$ (2.8), 63 (2.1), 392/83 (3.5), 395 (2.18); Pirani, J.R. 1993 (3.18), 51298 (2.18), 51308 (2.7); Pontes, T.A. 296 (2.18); Popovkin, A.V. 6 (2.1), 598, 617 (2.10), 667, 674 (3.5), 703, 744, 758, 825, 878, 885, 913, 1126, 1146, 1464 (2.10); Prance, G.T. 3352 (3.7); Prates, A.R.S. 32, 130, 232 (2.8); Queiroz, L.P. 599, 1801, 1851, 1954 (2.18), 1961 (1.1), 3852 (2.18), 4213 (1.1), 4751 (2.1), 5068 (1.1), 5358 (2.11), 5461 (2.14), 5476 (2.11), 5523 (2.20), 5589 (2.18), 5907 (2.17), 7385 , 7401, 7654, 8004, 8018, 8035 (3.18), 9319 (2.18), 9354, 9497 (2.12), 9604, 9613 (3.18), 9738 (2.18), 9774 (2.8), 9841,9992 (3.5), 10750 (2.4), 10861, 10930 (3.18), 12081 (2.19), 12953 (3.13), 13710 (1.1), 14566 (2.18), 18642 (1.1), 37045 (2.18); Ramos, C.H.A. 190 (2.13); Rapini, A. 983, 993 (2.18), 1479 (3.9); Ribeiro, P.L. 247 (2.14); Ribeiro, T. 160 (2.11), 330 (2.18); Rylands, A. 33 (3.14); Rizzini, C.T. 1067 (1.1); Rocha, D. 1118 (3.3); Rocha, F.F. 3, 49 (2.18); Roque, N. 717 (1.1),1033, 1587, 1911, 2026, 2275, 2817 (2.18), 2923 (1.1), 2989 (2.18), 3172 (1.1), 3428 (2.12), 3439 (2.18), 3512, 3543 (1.1), 4071, 4253 (2.18), 4390 (1.1), 15030 (2.9); Saavedra, M.M. 1004 (1.1); Salimena-Pires, F.R. 360 (2.18); Sano, P.T. 14449 (2.11); Santana, D.L. 447 (3.15); Sant'Ana, S.C. 208 (3.3), 242 (2.18); Santos, A.K.A. 755 (2.18), 939 (2.7), 1144 (2.18); Santos, E.B. 317 (2.13); Santos, F.S. 87 (2.1), 243 (2.13), 847 (3.5); Santos, N.N.A. s.n. HUEFS 10068 (2.18); Santos, R.M. 1386 (3.19); Santos, T.S. 725 (2.8), 727 (3.16), 784 (2.8), 790, 914 (2.13), 1062 (3.9), 1177, 1234 (2.13), 1250 (3.19), 1363 (2.13), 1489 (3.1), 1757 (3.2), 2055 (3.16), 2209, 2322 (2.13), 2683 (3.2), 2799, 2967 (2.13), 3012 (3.3), 3141 (3.9), 3220 (2.8) 3444 (3.17); Santos, V.J. 509 (2.8); Sátiro, L.N. 8 (2.18); Silva, C. 717 (2.5); Silva, F.B.L. 17 (3.18); Silva, J.R. s.n ALCB 20705 (2.1); Silva, 
L.A.M. 608, 760 (2.8), 994, 1033, 1544 (2.13), 1599 (2.18), 1777 (3.4), 2304 (3.13), 2751 (2.18), 2766 (1.1), 3418 (2.19), 4142 (2.8), 4347 (2.13); Silva, M.M. 429, 497 (3.18); Silva, M.S. 17 (2.1); Silva, U.C.S. 13 (2.1); Silva-Pereira, V. 50 (2.18); Silveira, E. s.n. ALCB 99020 (1.1); Schomburgk, R.H. 777/1516B (3.10); Sobral, M. 7531, 7542 (2.18), 7630 (2.11); Sobrinho, J.G.C. 653 , 710 (1.1); Souza, E.B. 1379 (2.14), 1389 (2.12), 1415 (2.5); Souza, I.M. 72 (2.18); Souza, M.C. 390 (3.4); Souza, V.C. 9918 (2.3), 22617, 26024 (2.18), 50271 (2.8); Souza-Silva, R.F. 30 (2.12); Stannard, B. 51120 , 51685 (2.6), 52773 (1.1); Stradmann, M.T.S. 506 (2.18), 681, 1013, 1129 (1.1); Taylor, N.P. 1589 (2.18); Thomas, W.W. 7032, 8543 (3.17), 8645 (3.4), 9194, 9265 (2.13), 9918 (3.1), 10002 (3.5), 10092 (2.8), 10362 (2.13), 10739 (2.1), 10825 (3.10), 10887 (3.3), 10914, 10918, 10926 (3.17), 11511 (3.5), 12241 (2.13), 12879 (2.18); Vaillant, P. 32 (2.18); Valadão, R.M. 442, 638 (2.13); van den Berg, C. 1884 (2.18); Verger, P. s.n. ALCB 114239 (2.1); Villa-Flor, M.L. 1 (2.1); Vinha, S.G. 133 (3.3); Walter, B.M.T. 277 (3.15); Wanderley, M.G.L. 1525 (2.7); Xavier, A.B. 349 (2.1); Zappi, D.C. 3454 (2.13). 